\title{
WATER-QUALITY ASSESSMENT OF THE KENTUCKY RIVER BASIN, KENTUCKY: RESULTS OF INVESTIGATIONS OF SURFACE-WATER QUALITY, 1987-90
}

By Kim H. Haag, Rene Garcia, G. Lynn Jarrett, and Stephen D. Porter

U.S. GEOLOGICAL SURVEY

Water-Resources Investigations Report 95-4163

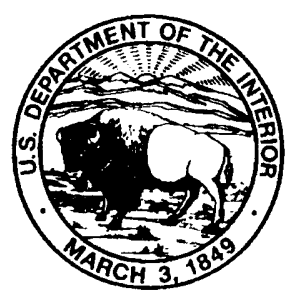

Louisville, Kentucky 


\title{
U.S. DEPARTMENT OF THE INTERIOR BRUCE BABBITT, Secretary
}

\author{
U.S. GEOLOGICAL SURVEY \\ Gordon P. Eaton, Director
}

For additional information write to:

Copies of this report can be purchased from:

District Chief

U.S. Geological Survey

District Office

2301 Bradley Avenue

Louisville, KY 40217
U.S. Geological Survey

Earth Science Information Center

Open-File Reports Section

Box 25286, MS 517

Denver Federal Center

Denver, CO 80225 


\section{FOREWORD}

The mission of the U.S. Geological Survey (USGS) is to assess the quantity and quality of the earth resources of the Nation and to provide information that will assist resource managers and policymakers at Federal, State, and local levels in making sound decisions. Assessment of water-quality conditions and trends is an important part of this overall mission.

One of the greatest challenges faced by water-resources scientists is acquiring reliable information that will guide the use and protection of the Nation's water resources. That challenge is being addressed by Federal, State, interstate, and local water-resource agencies and by many academic institutions. These organizations are collecting water-quality data for a host of purposes that include: compliance with permits and water-supply standards; development of remediation plans for a specific contamination problem; operational decisions on industrial, wastewater, or water-supply facilities; and research on factors that affect water quality. An additional need for water-quality information is to provide a basis on which regional and national-level policy decisions can be based. Wise decisions must be based on sound information. As a society we need to know whether certain types of water-quality problems are isolated or ubiquitous, whether there are significant differences in conditions among regions, whether the conditions are changing over time, and why these conditions change from place to place and over time. The information can be used to help determine the efficacy of existing water-quality policies and to help analysts determine the need for and likely consequences of new policies.

To address these needs, the Congress appropriated funds in 1986 for the USGS to begin a pilot program in seven project areas to develop and refine the National Water-Quality Assessment (NAWQA) Program. In 1991, the USGS began full implementation of the program. The NAWQA Program builds upon an existing base of water-quality studies of the USGS, as well as those of other Federal, State, and local agencies. The objectives of the NAWQA Program are to:

- Describe current water-quality conditions for a large part of the Nation's freshwater streams, rivers, and aquifers.

- Describe how water quality is changing over time.

- Improve understanding of the primary natural and human factors that affect water-quality conditions.

This information will help support the development and evaluation of management, regulatory, and monitoring decisions by other Federal, State, and local agencies to protect, use, and enhance water resources.

The goals of the NAWQA Program are being achieved through ongoing and proposed investigations of 60 of the Nation's most important river basins and aquifer systems, which are referred to as study units. These study units are distributed throughout the Nation and cover a diversity of hydrogeologic settings. More than two-thirds of the Nation's freshwater use occurs within the 60 study units and more than twothirds of the people served by public water-supply systems live within their boundaries.

National synthesis of data analysis, based on aggregation of comparable information obtained from the study units, is a major component of the program. This effort focuses on selected water-quality topics using nationally consistent information. Comparative studies will explain differences and similarities in observed water-quality conditions among study areas and will identify changes and trends and their causes. The first topics addressed by the national synthesis are pesticides, nutrients, volatile organic 
compounds, and aquatic biology. Discussions on these and other water-quality topics will be published in periodic summaries of the quality of the Nation's ground and surface water as the information becomes available.

This report is an element of the comprehensive body of information developed as part of the NAWQA Program. The program depends heavily on the advice, cooperation, and information from many Federal, State, interstate, Tribal and local agencies, and the public. The assistance and suggestions of all are greatly appreciated.

$$
\text { Robest m. Itiveh }
$$

Robert M. Hirsch

Chief Hydrologist 


\section{CONTENTS}

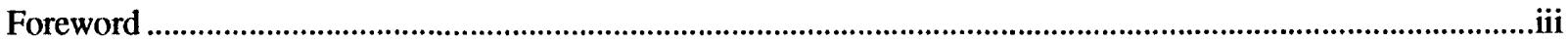

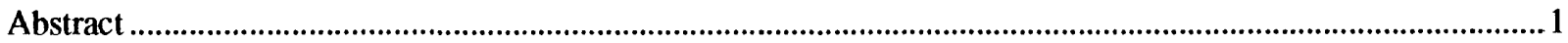

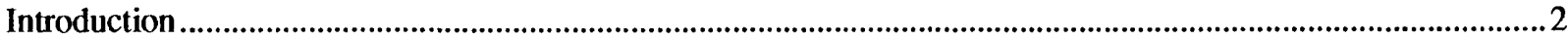

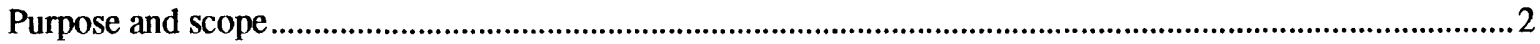

Surface-water-quality issues in the Kentucky River Basin............................................................................... 2

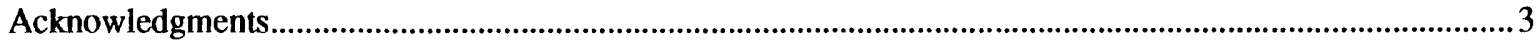

Description of the Kentucky River Basin ............................................................................................................

Physiography and topography................................................................................................................6

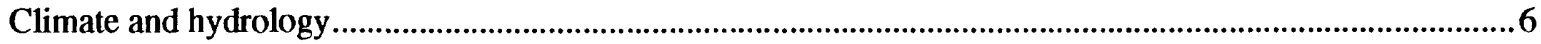

Population and land use ................................................................................................................................

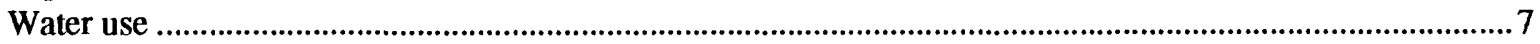

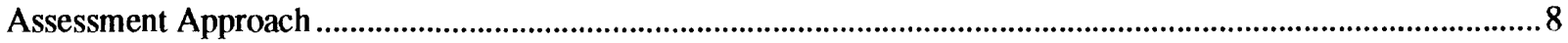

Design of field investigations and methods of data collection …………........................................................ 8

Effects of oil production ......................................................................................................................

Metals and other trace elements ......................................................................................................... 12

Nutrients, suspended sediments, and pesticides .......................................................................................12

Major ions and radionuclides................................................................................................................ 13

Synthetic organic compounds other than pesticides...................................................................................13

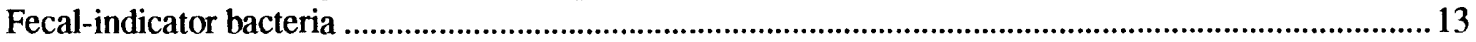

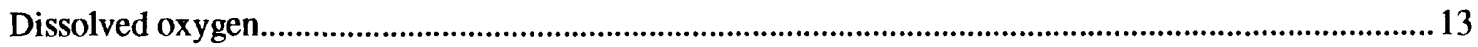

Quality assurance and quality control.......................................................................................................... 15

Results of investigations of surface-water quality ..............................................................................................15

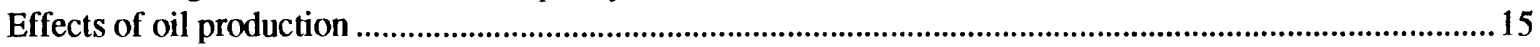

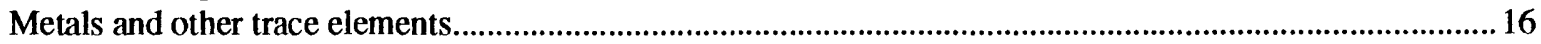

Nutrients, sediments, and pesticides .......................................................................................................... 18

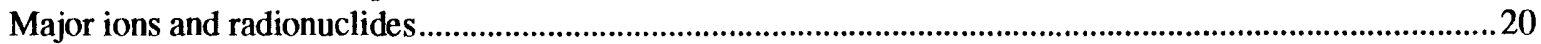

Synthetic organic compounds other than pesticides ......................................................................................... 30

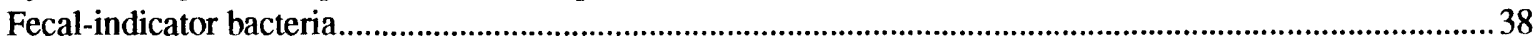

Basin-scale distribution of fecal-indicator bacteria ................................................................................. 38

Seasonal distribution of fecal-indicator bacteria ................................................................................40

Exceedences of State water-quality criteria for fecal-indicator bacteria ....................................................40

Subbasin-scale distribution of fecal-indicator bacteria during low flow...................................................4 43

Temporal trends in concentrations of fecal-indicator bacteria ................................................................44

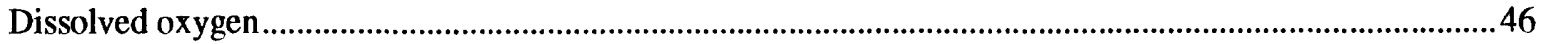

Effects of dissolved oxygen on water quality ....................................................................................46

Exceedences of State water-quality standards for dissolved oxygen ..........................................................49

Dissolved-oxygen modeling in the Kentucky River Basin.........................................................................49

Spatial variability of dissolved-oxygen concentrations.......................................................................50

Cluster analysis of land-use data .......................................................................................................57

Development of the regression model ............................................................................................59

Summary of regression-model results ............................................................................................61

Summary and conclusions ..................................................................................................................6

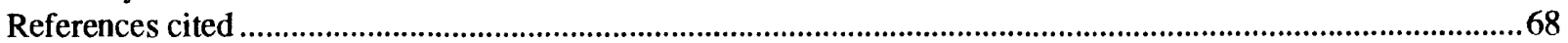


1-3. Maps showing:

1. Kentucky River and physiographic regions of the Kentucky River Basin 4

2. Location of fixed stations sampled during April 1987-March 1990 and synoptic sites sampled during August 24-28, 1987, and August 8-12, 1988, in the Kentucky River Basin.

3. Location of streambed-sediment sites sampled for nonpesticide organic compounds in October 1987 and November 1988 in the Kentucky River Basin

4. Boxplots of fecal-coliform counts at selected sites in the Kentucky River Basin,

April 1987-March 1990

5. Graph of smoothed fecal-coliform counts and percent flow duration in the North Fork Kentucky

River at Jackson and in the Kentucky River above Frankfort, April 1987-March 1990.

6-9. Maps showing:

6. Counts of Escherichia coli bacteria in the Kentucky River Basin during August 8-12, 1988

7. Concentration of dissolved oxygen in the North, Middle, and South Forks Kentucky River and associated tributaries, 1987-90

8. Concentration of dissolved oxygen in the Kentucky River and its tributaries from Lock 14 to the confluence with the Red River, 1987-90.

9. Concentration of dissolved oxygen in the Kentucky River and its tributaries from the confluence with the Red River to the confluence with the Ohio River, 1987-90.

10. Graph of percent saturation of dissolved oxygen in the Kentucky River main stem during

August 24-28, 1987, and August 8-12, 1988

11-14. Boxplots of:

11. Dissolved-oxygen concentrations measured in major tributary streams in the Kentucky River Basin during August 24-28, 1987, and August 8-12, 1988

12. Land-use distribution in each of the land-use clusters in the Kentucky River Basin .... 58

13. Dissolved-ox ygen concentrations in streams in the forested land-use cluster in the Kentucky River Basin during April 1987-March 1990

14. Dissolved-oxygen concentrations in streams in the agricultural land-use cluster in the Kentucky River Basin during April 1987-March 1990.

\section{TABLES}

1. Characterization of the seven fixed stations in the Kentucky River Basin .............................................

2. Location of the synoptic sites in the Kentucky River Basin ........................................................... 10

3. Statistical summary of concentrations of major ions at the fixed stations in the Kentucky River Basin

4. Estimated loads and yields of major ions at the fixed stations in the Kentucky River Basin, April 1987-March 1990

5. Statistical summary of radioisotope concentrations at the fixed stations in the Kentucky River Basin

6. Concentrations of organic compounds in streambed sediments collected during reconnaissance sampling at 13 streambed-sampling sites in the Kentucky River Basin, October 22, 1987

7. Concentrations of organic compounds in streambed sediments collected at 26 streambed-sampling sites in the Kentucky River Basin, November 1988

8. Statistical summary of fecal-indicator bacteria counts at selected streambed-sampling sites in the Kentucky River Basin ....

9. Number of fecal-indicator bacteria measurements in the Kentucky River Basin and percentage not meeting indicated water-quality criteria during October 1976-September 1990.

10. Statistical summary of fecal-indicator bacteria counts in the Kentucky River Basin collected during the synoptic survey in August 1988

11. Number of Escherichia coli measurements and percentage not meeting indicated water-quality criteria in the Kentucky River Basin during the synoptic survey in August 1988. 
12. Trend-test results for fecal-indicator bacteria counts at selected sites in the Kentucky

River Basin.

13. Dissolved-oxygen concentrations in streams tributary to the Kentucky River downstream

from Lock 14, 1987-90.

14. Critical dissolved-oxygen concentrations in streams throughout the four physiographic regions of the Kentucky River Basin, 1987-90.

15. Critical dissolved-oxygen concentrations in drainage basins of different sizes in the Kentucky

River Basin, 1987-90

16. Characterization of land use in each of the two land-use clusters used for development of a dissolved-oxygen model for the Kentucky River Basin

17. Distribution of water samples collected for dissolved-oxygen analyses in each physiographic region in the forested and agricultural land-use clusters in the Kentucky River Basin.

18. Statistics for the multiple-regression dissolved-ox ygen model for the forested land-use cluster in the Kentucky River Basin.

19. Statistics for the multiple-regression dissolved-ox ygen model for the agricultural land-use cluster in the Kentucky River Basin

\section{CONVERSION FACTORS, VERTICAL DATUM, AND ABBREVIATIONS}

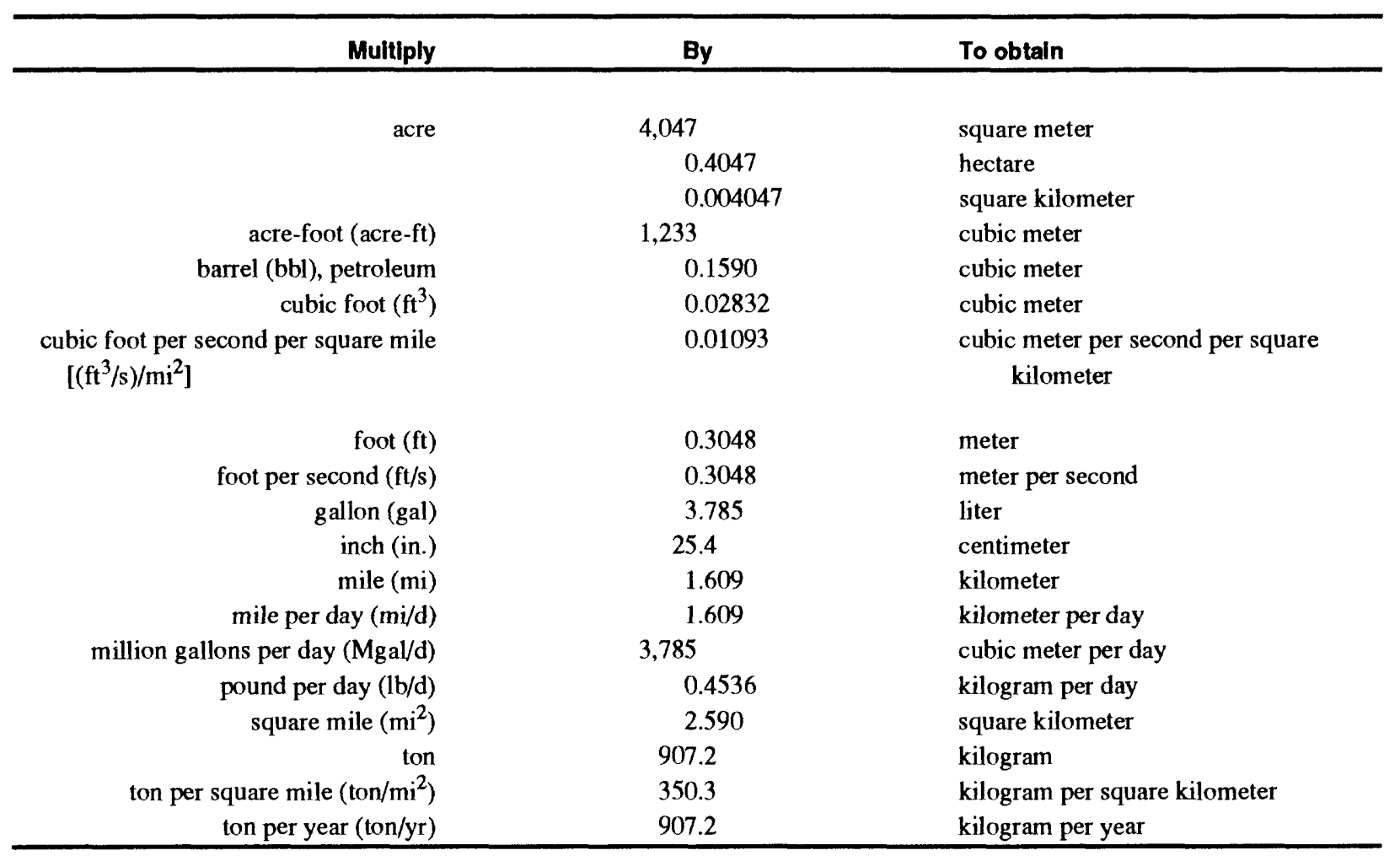

Degrees Celsius $\left({ }^{\circ} \mathrm{C}\right)$ may be converted to degrees Fahrenheit $\left({ }^{\circ} \mathrm{F}\right)$ by use of the following equation:

$$
{ }^{\circ} \mathrm{F}=(9 / 5)\left({ }^{\circ} \mathrm{C}\right)+32
$$

Sea level: In this report "sea level" refers to the National Geodetic Vertical Datum of 1929 (NGVD of 1929) - a geodetic datum derived from a general adjustment of the first-order level nets of both the United States and Canada, formerly called Sea Level Datum of 1929. 
Abbreviated water-quality units used in this report: Chemical concentrations and water temperatures are given in metric units. Chemical concentration of constituents in solution or suspension is given in milligrams per liter $(\mathrm{mg} / \mathrm{L}$ ) or micrograms per liter $(\mu \mathrm{g} / \mathrm{L})$. Milligrams per liter is a unit expressing the concentration of chemical constituents in solution as weight (milligrams) of solute per unit volume (liter) of water. One thousand micrograms per liter is equivalent to one milligram per liter. For concentrations less than $7,000 \mathrm{mg} / \mathrm{L}$, the numerical value is the same as the concentration in parts per million. Chemical concentration of constituents in soil or streambed sediment is given in milligrams or micrograms of constituent per kilogram of soil or sediment $(\mathrm{mg} / \mathrm{kg}$ or $\mu \mathrm{g} / \mathrm{kg}$ ).

Bacteria densities are expressed as number of colonies per 100 milliliters of water $(\mathrm{col} / 100 \mathrm{~mL})$.

Radioactivity is expressed in picocuries per liter $(\mathrm{pCi} / \mathrm{L})$. A picocurie is one-trillionth $\left(1 \times 10^{-12}\right)$ the amount of radioactivity represented by a curie $(\mathrm{C} i)$. A curie is the amount of radioactivity that yields $3.7 \times 10^{10}$ radioactive disintegrations per second. A picocurie yields 2.22 disintegrations per minute.

Water year: The 12-month period from October 1 through September 30 . The water year is designated by the calendar year in which it ends.

Any use of trade, product, or firm names in this publication is for descriptive purposes only and does not imply endorsement by the U.S. Government. 


\title{
Water-Quality Assessment of the Kentucky River Basin, Kentucky: Results of Investigations of Surface-Water Quality, 1987-90
}

\author{
By Kim H. Haag, Rene Garcia, G. Lynn Jarrett, and Stephen D. Porter
}

\begin{abstract}
The U.S. Geological Survey investigated the water quality of the Kentucky River Basin, Ky., as part of the National Water-Quality Assessment Program. Data collected during 1987-90 were used to describe the spatial and temporal variability of surface-water constituents including major and minor ions, metals, trace elements, nutrients, sediments, pesticides, dissolved oxygen, and fecal-coliform bacteria. Efforts were made to determine the influence of land use on water quality.
\end{abstract}

Oil-production activities were the source of barium, bromide, chloride, magnesium, and sodium in several subbasins. High concentrations of aluminum, iron, and zinc were related to surface mining in the Eastern Coal Field Region. High concentrations of lead and zinc were found in streambed sediments in urban areas, whereas high concentrations of arsenic, strontium, and uranium were associated with natural geologic sources.

Concentrations of phosphorus were significantly correlated with urban and agricultural land use. The high phosphorus content of Bluegrass Region soils was an important source of phosphorus in streams. At many sites in urban areas, most of the stream nitrogen load was attributable to WWTP effluent. Average suspended-sediment concentrations were positively correlated with streamflow. A downward trend in suspended-sediment concentrations downstream was detected in the Kentucky River main stem during the study. The most frequently detected herbicides in water samples were atrazine, 2,4-D, alachlor, metolachlor, and dicamba. Diazinon, malathion, and parathion were the most frequently detected organophosphate insecticides in water samples. Detectable concentrations of aldrin, chlorodane, DDT, DDE, dieldrin, endrin, endosulfan, heptachlor, and lindane were found in streambed-sediment samples.

Dissolved-oxygen concentrations generally exceeded the minimum concentration needed to sustain aquatic life. Median dissolved-oxygen concentrations were higher and less variable in subbasins where forest was the dominant land-use type. High nutrient concentrations and associated high organic-carbon content may have contributed to low dissolved-oxygen concentrations in subbasins where agricultural land use was dominant. About 375 to 575 river miles in the Kentucky River Basin were contaminated by fecal-coliform bacteria during 1988. Almost one-third of the 29 sampling stations in the basin where counts of Escherichia coli did not meet full-body-contact criteria were located in the North Fork of the Kentucky River. Median counts of fecal-coliform bacteria decreased in the upper part of the Kentucky River Basin during 1980-90. 


\section{INTRODUCTION}

The U.S. Geological Survey (USGS), as part of the USGS National Water-Quality Assessment (NAWQA) Program, has studied the streams in the Kentucky River Basin to assess surface-water quality. Data were collected to assess the sources, occurrence, distribution, and fate of constituents in oil-brine discharges; concentrations of metals and trace elements, nutrients, sediments, pesticides, major ions, and radionuclides; synthetic organic compounds other than pesticides; dissolved oxygen; and counts of fecalindicator bacteria. The information generated in these studies is available to water managers, policymakers, and the public to improve the effectiveness of water-quality management and to aid in the assessment of proposed changes in land- and water-management practices.

\section{Purpose and Scope}

The purpose of this report is to present results of the Kentucky River Basin pilot NAWQA project by (1) briefly summarizing data previously published in NAWQA reports for the Kentucky River Basin that describe (a) the effects of oil production on water quality and (b) the distribution of metals and other trace elements, nutrients, sediment, and pesticides in surface waters in the basin; (2) presenting analyses of additional data collected to describe the distribution and trends in concentrations of major ions, radionuclides, synthetic organic compounds other than pesticides, fecal-indicator bacteria, and dissolved oxygen; and (3) summarizing all the data collected in the pilot project to describe comprehensively the quality of water in streams of the Kentucky River Basin during 1987-90.

\section{Surface-Water-Quality Issues in the Kentucky River Basin}

National target variables in the NAWQA pilot program consist of a set of measurements of physical conditions and concentrations of organic and inorganic compounds for all study units. Additional target variables were selected for each study unit by the project team to supplement the national list, and their inclusion reflects regional concerns as well as issues unique to the specific study unit. Because waterquality conditions can be assessed by measuring an almost limitless number of constituents, the challenge to water-resource managers is to determine which constituents are the most relevant, diagnostic, and costetfectıve to measure.

In the Kentucky River Basin, several constituents have been identified as relevant to important surface-water-quality issues. These include major cations and anions, nutrients, dissolved oxygen, fecalindicator bacteria, and various synthetic organic compounds. In addition, the issues related to sediment, metals, and trace elements have important implications for water quality in the Kentucky River Basin.

The general quality of water within the Kentucky River Basin depends, in large part, on the geology of the basin. The headwaters areas of the basin in the Eastern Coal Field are underlain by sandstone, siltstone, and shale; the Knobs is underlain bv sandv limestones and sandstone caprock: and the karstic Bluegrass Region is underlain by phosphatic limestone. Atmospheric deposition can affect the mobilization of constituents in geologic formations and soils and can alter $\mathrm{pH}$ in surface water throughout the basin.

The development of natural resources, including coal and oil in the Knobs and Eastern Coal Field Regions, has adversely affected the quality of some surface waters in the basin. Acidic runoff from coal mines, brines pumped from oil wells, and erosion of overburden induced by land development are some of the human activities that have degraded surface-water qualitv. Water use in general is increasing in intensity as urban areas expand. Water-use categories of growing importance include residential use. industrial use, and broad-scale recreational use. Stormwater discharges from urbanized areas. particularlv 
in and around Lexington and Frankfort, are of concern as nonpoint sources of potentially hazardous contaminants. Land disturbance associated with building and road construction, deforestation, and agriculture have increased erosion and sediment loads in streams. Eutrophication, or the enrichment of receiving streams with anthropogenic nutrients, is occurring in some agricultural areas within the basin because of the wide use of fertilizers. Improperly or incompletely treated municipal-wastewater discharges continue to be point sources of stream contaminants, particularly fecal-indicator bacteria.

Altered concentrations of the various surface-water constituents described above are of concern from the standpoint of their effects on aquatic life. Direct effects are significant and, perhaps, best understood. Synergistic effects are less well studied and often unappreciated; these include interactions between low concentrations of dissolved oxygen, elevated concentrations of pesticides, sediment deposition, and other factors. Many stream reaches in the basin continue to support a large and diverse aquatic faunal community. Among these are parts of Buckhorn Creek, Eagle Creek, and Elkhom Creek, Jessamine Creek, the Dix River system, Red River, and reaches of the Middle and South Forks of the Kentucky River (Bradfield and Porter, 1990). Surface-water quality generally meets Federal and State water-quality criteria and is suitable to support designated uses (Kentucky Natural Resources and Environmental Protection Cabinet, 1992a). The 1986 report to Congress for Kentucky assessed water-quality conditions for approximately 900 of the 3,450 stream miles in the Kentucky River Basin and stated that only 6 percent of the stream miles assessed were significantly affected by water contamination (White and others, 1987). However, expected increases in population and industrial growth will increase water use, and several municipal dischargers will require additional treatment facilities to prevent exceedence of water-quality standards. Moreover, continued agricultural development has the potential for increasing inputs of nutrients, sediments, and pesticides. Accelerated eutrophication may result from nutrient inputs from municipal, agricultural, and urban nonpoint sources. The effects of these changing conditions on aquatic life is not well understood.

\section{Acknowledgments}

The NAWQA project liaison committee for the Kentucky River Basin provided continued guidance and input to this project. Members of the committee included representatives from the U.S. Fish and Wildlife Service; Kentucky Department of Agriculture; Kentucky Natural Resources and Environmental Protection Cabinet; Kentucky Department of Fish and Wildlife Resources; Kentucky Geological Survey; and Kentucky Water Resources Research Institute.

Many people and organizations assisted in the preparation of this report. The authors are especially grateful to Emest Collins of the Kentucky Division of Pesticides, Vicki Ray of the Kentucky Natural Resources and Environmental Protection Cabinet, and Corine Wells of the Kentucky Division of Water. Ronald D. Evaldi, U.S. Geological Survey, provided guidance to the authors, and this summary report benefited significantly from his perspective on the Kentucky River Basin NAWQA project from its inception.

\section{DESCRIPTION OF THE KENTUCKY RIVER BASIN}

The Kentucky River Basin, located in east-central Kentucky, has a drainage area of about 7,000 $\mathrm{mi}^{2}$ and includes about 3,500 mi of streams (Smoot and others, 1991). The main stem of the Kentucky River originates in southeastem Kentucky and flows northwestward approximately $405 \mathrm{mi}$ to its confluence with the Ohio River at Carrollton (fig. 1). Major tributaries include the North, Middle, and South Forks Kentucky River; Red River; Dix River; Elkhom Creek; and Eagle Creek (fig. 2). The Kentucky River 


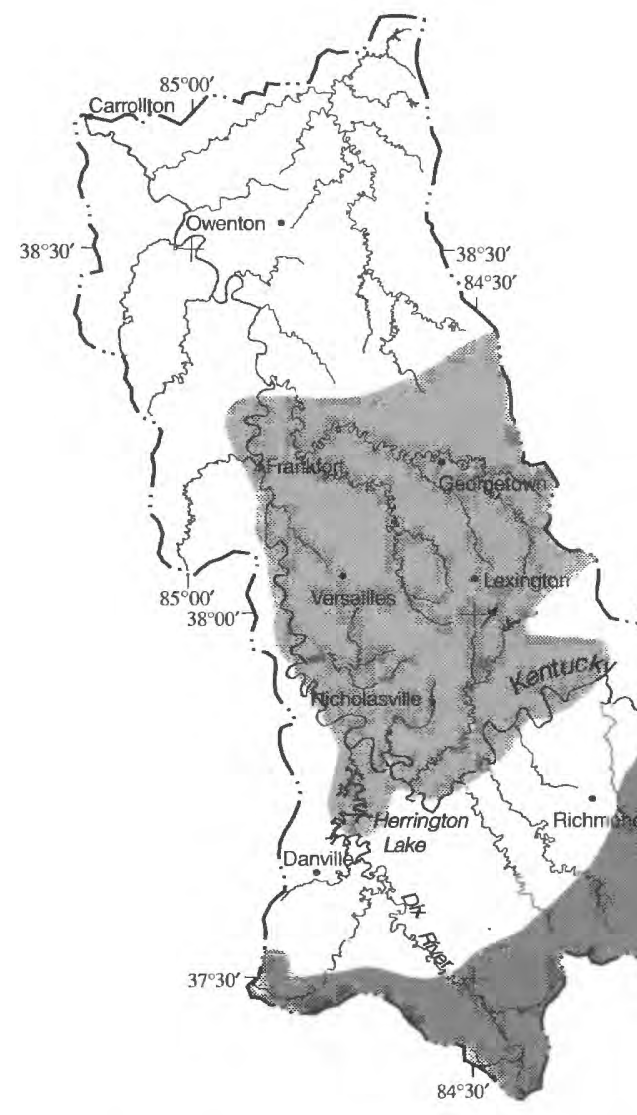

Base from U.S. Geological Survey digital data, 1:100,000, 1983 Universal Transverse Mercator projection, Zone 16
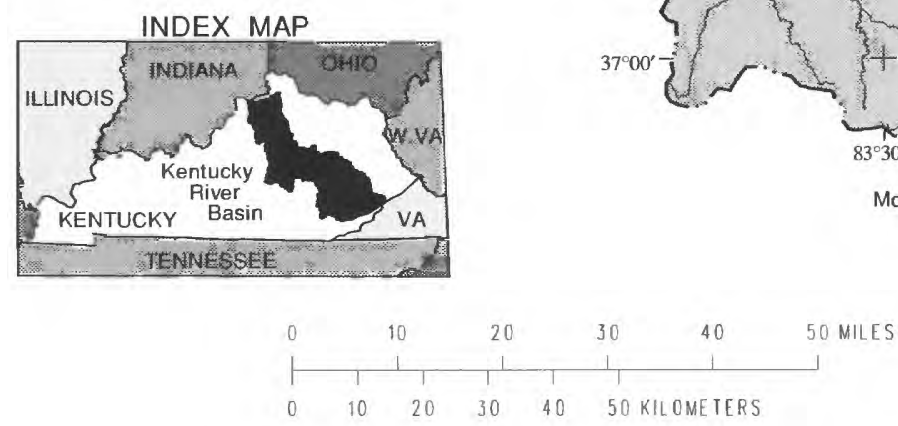

Figure 1. Kentucky River and physiographic regions of the Kentucky River Basin. 


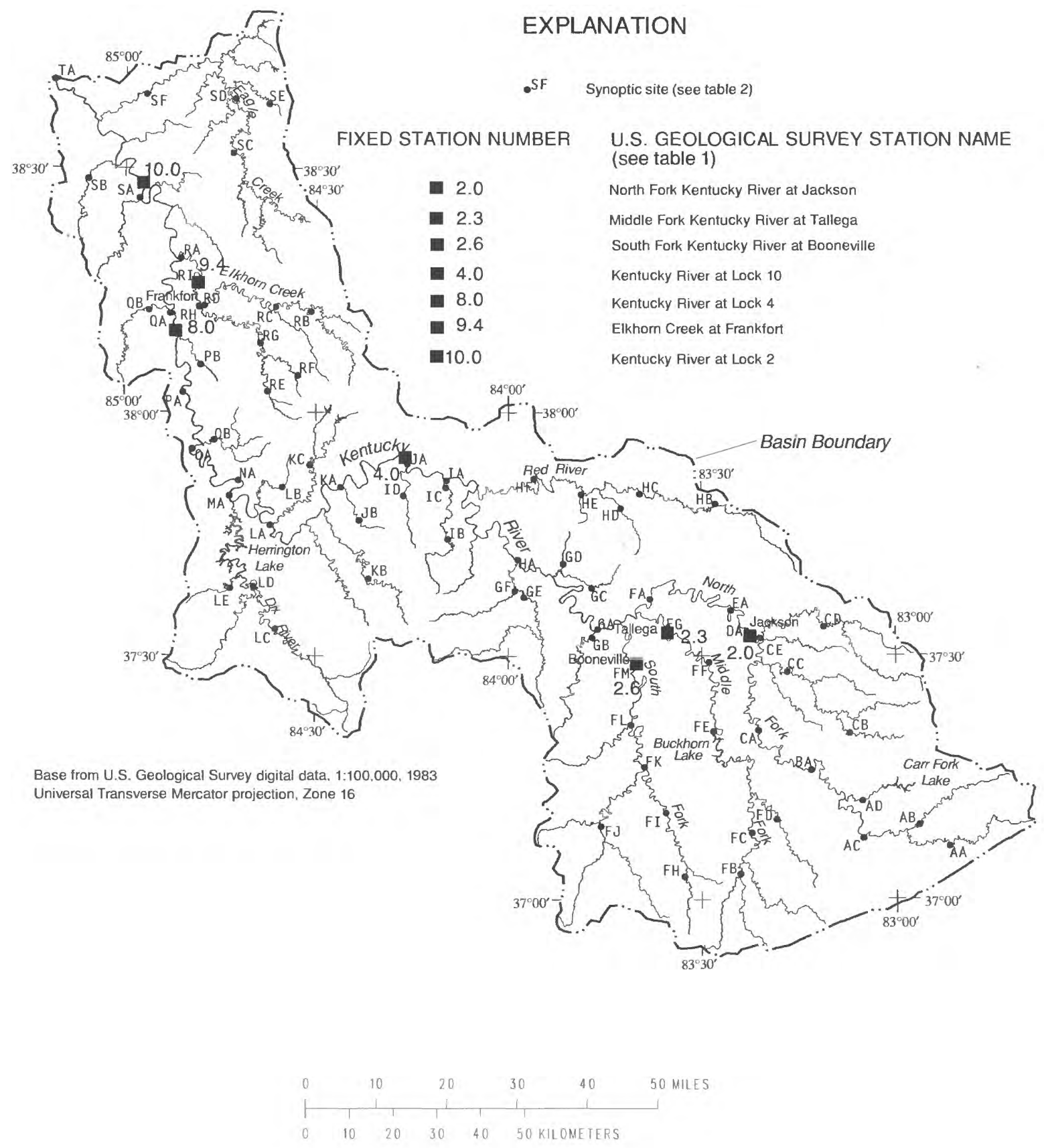

Figure 2. Location of fixed stations sampled during April 1987-March 1990 and synoptic sites sampled during August 24-28, 1987, and August 8-12, 1988, in the Kentucky River Basin. 
drains all or parts of 39 counties in the State and serves as a source of drinking water for 95 percent of the basin population. The population, which numbered about 649,000 in 1990 , is concentrated in a few counties.

\section{Physiography and Topography}

Detailed descriptions of the physiography, geology, and land-use patterns in the Kentucky River Basin have been published in Smoot and others (1991) and Porter and others (1995). The basin consists of four physiographic regions: the Eastem Coal Field, the Knobs, the Inner Bluegrass, and the Outer Bluegrass (fig. 1). Surface-water characteristics, land-use patterns, and population distribution differ among the regions. These variations are discussed with respect to their effects on water quality.

The southem part of the basin lies within the Eastern Coal Field Region. Elevation ranges from 1,000 to 3,200 ft above sea level, and terrain consists of narrow valleys and narrow, steep-sided ridges. Soils, which are moderately deep and generally well drained, are formed from siltstones, sandstones, and shales. About 98,000 acres of land have been directly affected by coal-mining activities. Kentucky is a leading producer of bituminous coal, and about 25 percent of the State's coal is mined in the Kentucky River Basin. Much of the Eastem Coal Field Region is forested; 90 percent of the harvested timber is hardwood.

The Knobs Region, characterized by its distinctive conical and flat-topped hills, separates the Eastem Coal Field Region from the Bluegrass Region in Kentucky. Broad valleys underlain by shale separate the sandy limestone and sandstone caprock of the hills. Elevation ranges from 600 to more than 1,600 $\mathrm{ft}$ above sea level. Soils are shallow and clayey and consequently poorly drained because of a dense subsurface layer of compacted silt overlaying shale (U.S. Department of Agriculture, 1981). Much of the region is forested, and production of oil and gas is a major activity.

The Inner Bluegrass Region is in the north-central part of the basin and is characterized by gently rolling upland underlain by thick-bedded phosphatic limestone. Elevation ranges from 800 to $1,000 \mathrm{ft}$ above sea level. Considerable surface and subsurface solution of bedrock has resulted in extensive karst topography in this region. Soils developed from the phosphatic limestone are moderately deep and generally well drained; they consist of silty loam over a clayey subsoil.

The remaining, northern part of the basin lies within the Outer Bluegrass Region. Elevation ranges from 800 to $1,000 \mathrm{ft}$ above sea level, and areas near streams are dissected and rugged. The Outer Bluegrass Region is underlain by thin-bedded limestone interbedded with considerable shale. Some surface and subsurface solution has resulted in small sinkholes and subdued karst topography. Soils are moderately deep, fairly well drained, and generally suitable for farming.

\section{Climate and Hydrology}

The climate and hydrology of the Kentucky River Basin are described in Smoot and others (1991). In brief, the climate is temperate and humid. Mean annual temperature is $56^{\circ} \mathrm{F}\left(13^{\circ} \mathrm{C}\right)$; daily mean temperatures range from $25^{\circ} \mathrm{F}\left(-4^{\circ} \mathrm{C}\right)$ in January and February to $87^{\circ} \mathrm{F}\left(31^{\circ} \mathrm{C}\right)$ in July and August (U.S. Department of Agriculture, 1981). Annual precipitation averages $46 \mathrm{in}$., ranging from $40 \mathrm{in}$. in the northern part of the basin to $48 \mathrm{in}$. in the southem part (Elam and others, 1972). March is typically the wettest month. and October is the driest. 
Runoff and ground-water recharge in the basin vary temporally and spatially (Smoot and others, 1991). Basinwide, 28 percent of the annual precipitation results in surface runoff, and 9 percent recharges the ground-water reservoir. Runoff is greater in the mountains of the Eastern Coal Field Region than it is in the Inner and Outer Bluegrass Regions. Within the Bluegrass Region, considerable rainfall recharges the ground-water reservoir directly through sinkholes.

Streamflow is variable throughout the basin because of differences in geology, topography, and land use. Streams flowing across the highly permeable karst terrain of the Bluegrass regions commonly consist of dry and flowing reaches, depending on the extent of karst development. The average annual unit flow of streams in the study area is $1.4\left(\mathrm{ft}^{3} / \mathrm{s}\right) / \mathrm{mi}^{2}$. During hydrologic extremes, however, unit flows differ substantially. Unit peak flow in the basin ranged from $344\left(\mathrm{ft}^{3} / \mathrm{s}\right) / \mathrm{mi}^{2}$ at Cutshin Creek at Wooton to $18.3\left(\mathrm{ft}^{3} / \mathrm{s}\right) / \mathrm{mi}^{2}$ in the Kentucky River at Lock 2 . Hydrographs of daily mean streamflow and instantaneous streamflow at the time of water-quality sampling, as well as the flow-duration curve during April 1987March 1990 at Lock 2 on the Kentucky River, were published in Haag and Porter (1995). With the exception of extremely low flows, sampling at the fixed sampling sites during this study covered the entire range of the flow duration.

The flow of the Kentucky River main stem is regulated by 14 lock and dam structures that maintain at least $6 \mathrm{ft}$ of water for navigation from a point just downstream from the confluence of the North, Middle, and South Forks to the mouth. The Kentucky River Basin has no natural lakes. A total of 15 reservoirs in the basin have a combined volume of 286,000 acre- $\mathrm{ft}$ and a combined surface area of 6,530 acres. Three major reservoirs-Herrington, Buckhom, and Carr Fork-comprise 75 percent of total reservoir surface area and 90 percent of total reservoir volume. The operation of reservoirs for flood control and low-flow augmentation has resulted in moderation of postimpoundment flow extremes.

\section{Population and Land Use}

Population in the Kentucky River Basin, estimated to be 649,260 in 1990 (Decker, 1991), is concentrated in a few counties. Population in the basin increased slightly (2.7 percent) from 1980 to 1990. Fourteen counties gained population, whereas at least 10 counties lost population during that interval. The largest increases were in counties surrounding the Lexington metropolitan area, and the greatest losses were in counties of the Eastem Coal Field Region.

Major land uses include forestry, agriculture, coal mining, and oil and gas production; the amount of urban land is also substantial (Smoot and others, 1991). Forests make up more than 50 percent of the basin land area, although they are concentrated principally in the Eastern Coal Field Region. More than 90 percent of the timber volume is hardwood species, principally hickory and poplar; the remainder consists of pines and eastern redcedar. Approximately 40 percent of the basin is devoted to agriculture, primarily in the Inner and Outer Bluegrass Regions. Com, soybeans, wheat, and tobacco are the dominant crops, and livestock includes horses, dairy and beef cattle, poultry, sheep, and goats. Bituminous coal is mined in the Eastern Coal Field Region, and oil and gas production are confined to the Knobs Region. Principal municipalities include Carrollton, Frankfort, Georgetown, Lexington, Danville, Richmond, and Hazard.

\section{Water Use}

In the Kentucky River Basin, water withdrawal differs considerably among subbasins, ranging from $1.66 \mathrm{Mgal} / \mathrm{d}$ in the Middle Fork Kentucky River to $70.0 \mathrm{Mgal} / \mathrm{d}$ in the lower Kentucky River. In all subbasins, the principal use of water withdrawn from surface supplies is for potable water supply. Surface 
water provides 95 percent of the public water supply basinwide. The largest municipalities supplying potable water are Lexington, Frankfort, and Richmond. Other water uses include industrial supply, recreation, commercial navigation, and propagation of fish and wildlife. The demand for water in the Bluegrass Region increased almost 20 percent between 1982 (64 Mgal/d) and 1987 (76 Mgal/d) (Don Hassall, Bluegrass Area Development District, written commun., 1992).

A total of 11 municipal WWTP's each discharge more than $1 \mathrm{Mgal} / \mathrm{d}$ of effluent into the Kentucky River Basin. In addition, 30 small municipal WWTP's each discharge wastewater quantities of less than $1 \mathrm{Mgal} / \mathrm{d}$. Approximately 250 small nonmunicipal WWTP's are permitted to operate within the Kentucky River Basin. At least 29 industrial facilities discharge more than $1 \mathrm{Mgal} / \mathrm{d}$ of wastewater to surface waters in the Kentucky River Basin.

\section{ASSESSMENT APPROACH}

Water-quality data for the Kentucky River Basin NAWQA pilot study were collected and analyzed to determine (1) the spatial, temporal, and streamflow-related variability of constituents throughout the basin, (2) the effects of point-source discharges - such as municipal and industrial effluents—on water quality, and (3) the effects of runoff from nonpoint sources - such as agricultural operations - on water quality. The target variables selected were constituents that are relevant to local, regional, or national water-quality issues, including nutrient enrichment, sedimentation, chemical contamination, and overall acceptability of water for use (Hirsch and others, 1988).

\section{Design of Field Investigations and Methods of Data Collection}

Seven fixed stations were located within the basin (fig. 2; table 1). These stations were selected after consideration of variations in geographic and hydrographic resolution, major tributaries, land use, water use, and the availability of historical water-quality or streamflow data. Fixed stations were located on each of the major upstream tributaries; namely, the North Fork, the Middle Fork, and the South Fork of the

Kentucky River. Three additional stations were located on the main stem of the river at river miles 176, 65, and 31. A seventh station was located on Elkhorn Creek near Frankfort; this creek drains the largest population center in the Kentucky River Basin. Fixed stations were sampled monthly for specific target constituents over the 3-year period from April 1987 through March 1990. A detailed description of station locations, sampling frequencies, WATSTORE codes, and detection levels for constituents at the fixedstation network in the Kentucky River Basin was compiled by Griffin and others (1994).

Synoptic studies (studies that involve nearly simultaneous measurements at multiple sites) were done to evaluate water quality for a brief period of time over a broad geographical area. Single samples were collected at many sites to provide information on the occurrence and distribution of selected constituents during stable low-flow conditions, when the effects of point-source discharges predominate. Synoptic study sites were selected on the basis of physiography, land use, point-source discharges, and other factors. Synoptic sites used in the assessment of nutrients, sediments, pesticides, fecal-indicator bacteria, and dissolved oxygen (fig. 2) are listed in table 2. 
Table 1. Characterization of the seven fixed stations in the Kentucky River Basin

$\left[\mathrm{mi}^{2}\right.$, square miles; $\mathrm{ft}^{3} / \mathrm{s}$, cubic feet per second; data from Melcher and Ruhl, 1984]

\begin{tabular}{|c|c|c|c|c|}
\hline $\begin{array}{l}\text { Station name } \\
\text { (Station number) }\end{array}$ & $\begin{array}{c}\text { Drainage } \\
\text { area } \\
\left(\mathbf{m}^{2}\right)\end{array}$ & $\begin{array}{c}\text { Average } \\
\text { dlscharge } \\
\left(\mathrm{ft}^{3} / 8\right)\end{array}$ & $\begin{array}{c}\text { 7-day } \\
\text { 10-year } \\
\text { low-flow } \\
\left(\mathrm{ft}^{3} / 8\right)\end{array}$ & $\begin{array}{l}\text { Average } \\
\text { specific } \\
\text { dlscharge } \\
{\left[\left(\mathrm{ft}^{3} / \mathbf{s}\right) / \mathrm{ml}^{2}\right]}\end{array}$ \\
\hline $\begin{array}{l}\text { North Fork Kentucky River at Jackson } \\
(2.0)\end{array}$ & 1,100 & 1,360 & 3.1 & 1.24 \\
\hline $\begin{array}{l}\text { Middle Fork Kentucky River at Tallega } \\
\text { (2.3) }\end{array}$ & 537 & 730 & .6 & 1.36 \\
\hline $\begin{array}{l}\text { South Fork Kentucky River at Booneville } \\
\text { (2.6) }\end{array}$ & 722 & 1,060 & 1.1 & 1.47 \\
\hline $\begin{array}{l}\text { Kentucky River at Lock } 10 \text {, near Winchester } \\
(4.0)\end{array}$ & 3,950 & 5,270 & 42.0 & 1.33 \\
\hline $\begin{array}{l}\text { Kentucky River at Lock 4, near Frankfort } \\
\text { (8.0) }\end{array}$ & 5,410 & 7,110 & 175 & 1.31 \\
\hline $\begin{array}{l}\text { Elkhorn Creek at Frankfort } \\
(9.4)\end{array}$ & 473 & 609 & 6.5 & 1.29 \\
\hline $\begin{array}{l}\text { Kentucky River at Lock 2, near Lockport } \\
(10.0)\end{array}$ & 6,180 & 8,320 & 206 & 1.35 \\
\hline
\end{tabular}

\section{Effects of Oil Production}

Streams in three subbasins in the Kentucky River Basin were studied to assess the effects of oil production (Evaldi and Kipp, 1991). The Cat Creek (see fig. 8) subbasin was chosen as the study control because no oil production was known to have occurred in the subbasin prior to or during the study. The Furnace Fork (see fig. 8) subbasin was chosen because of its long history of oil production and because reconnaissance sampling during 1985-87 indicated that it might not be as greatly affected by present-day oil-production activities as many other creeks in the Kentucky River Basin. The Big Sinking Creek Subbasin (see fig. 8) was selected for study because of extensive production activities in the watershed and because large concentrations of chloride were detected during reconnaissance sampling during 1985-87. Surface-water characteristics of the three subbasins were determined by monthly and storm-event sampling, and by continuous monitoring of streamflow and specific conductance during April 1987March 1989. Loads of selected constituents in the streams draining the three subbasins were estimated from the continuous-streamflow and constituent-concentration records. Monthly streamflow measurements and samples for chloride and bromide were collected for 2 years from six tributary streams upstream from the continuous monitoring site on Fumace Fork to further define constituent sources and transport mechanisms. Two low-flow synoptic surveys were conducted at 75 sites to determine the concentration and distribution of major ions throughout the Kentucky River Basin. The overall effect of oil-well-brine discharges on the Kentucky River was assessed using water-quality and streamflow records collected by the USGS at Lock 10 . Complete details of data collection, data analyses, and data storage were published in Evaldi and Kipp (1991). 
Table 2. Location of the synoptic sites in the Kentucky River Basin

[N, North; Ky, Kentucky; R, River, nr, near, Ck, Creek; M, Middle; S, South]

\begin{tabular}{|c|c|c|c|c|c|}
\hline Slte number & Site name & $\begin{array}{l}\text { Synoptic } \\
\text { site } \\
\text { code }\end{array}$ & $\begin{array}{c}\text { Drainage } \\
\text { area, In } \\
\text { square } \\
\text { miles }\end{array}$ & Lattidude' & Longitude $^{1}$ \\
\hline 03277305 & N Fork Ky R at Ice & AA & 85 & 370632 & 825149 \\
\hline 03277360 & Rockhouse Ck nr Letcher & $\mathrm{AB}$ & 51.5 & 370910 & 825628 \\
\hline 03277410 & Leatherwood $\mathrm{Ck}$ at Cornettsville & $\mathrm{AC}$ & 49.7 & 370735 & 830505 \\
\hline 03277470 & Carr Fork at Scuddy & $\mathrm{AD}$ & 79.7 & 371209 & 830513 \\
\hline 03277550 & N Fork Ky R at Combs & BA & 480 & 371558 & 831303 \\
\hline 03277690 & N Fork Ky R at Chavies & $\mathrm{CA}$ & 575 & 372052 & 832112 \\
\hline 03277835 & Troublesome Ck at Dwarf & $\mathrm{CB}$ & 59.9 & 372030 & 830707 \\
\hline 03279005 & Troublesome Ck nr Clayhole & $\mathrm{CC}$ & 195 & 372802 & 831647 \\
\hline 03279400 & Quicksand Ck at Lunah & $\mathrm{CD}$ & 101 & 373331 & 831104 \\
\hline 03279700 & Quicksand Ck at Quicksand & $\mathrm{CE}$ & 203 & 373211 & 832055 \\
\hline 03280000 & N Fork Ky R at Jackson & DA & 1,101 & 373246 & 832221 \\
\hline 03280120 & $\mathrm{~N}$ Fork Ky $\mathrm{R}$ at Frozen $\mathrm{Ck}$ & EA & 1,134 & 373534 & 832523 \\
\hline 03280500 & N Fork Ky R nr Airdale & FA & 1,294 & 373700 & 833800 \\
\hline 03280551 & M Fork Ky R at Asher & FB & 70.6 & 370310 & 832400 \\
\hline 03280600 & M Fork Ky R nr Hyden & FC & 202 & 370813 & 832217 \\
\hline 03280700 & Cutshin $\mathrm{Ck}$ at Wooton & FD & 61.3 & 370954 & 831829 \\
\hline 03280900 & M Fork Ky R at Buckhorn & FE & 420 & 372045 & 832807 \\
\hline 03280940 & M Fork Ky R nr Shoulderblade & $\mathrm{FF}$ & 475 & 372914 & 832850 \\
\hline 03281000 & M Fork Ky $\mathrm{R}$ at Tallega & FG & 537 & 373318 & 833538 \\
\hline 03281017 & Red Bird R nr Spring Ck & FH & 53 & 370253 & 833239 \\
\hline 03281040 & Red Bird R nr Big Ck & FI & 155 & 371043 & 833535 \\
\hline 03281100 & Goose Ck at Manchester & FJ & 163 & 370907 & 834537 \\
\hline 03281200 & S Fork Ky R at Oneida & FK & 486 & 371623 & 833850 \\
\hline 03281351 & Sexton Ck nr Taft & FL & 71.6 & 372133 & 834059 \\
\hline 03281500 & S Fork Ky R at Booneville & FM & 722 & 372845 & 834038 \\
\hline 03282000 & Ky $\mathrm{R}$ at Lock 14 , Heidelberg & GA & 2,657 & 373319 & 834606 \\
\hline 03282048 & Sturgeon Ck nr Ida May & GB & 110 & 373215 & 834658 \\
\hline 03282075 & Big Sinking Ck nr Crystal & GC & 23.4 & 373822 & 834705 \\
\hline 03282100 & Furnace Fork nr Crystal & GD & 9.94 & 374121 & 835127 \\
\hline 03282170 & Station Camp Ck at Wagersville & GE & 116 & 373715 & 835734 \\
\hline 03282190 & Redlick Ck nr Station Camp & GF & 69.5 & 373801 & 835901 \\
\hline
\end{tabular}


Table 2. Location of the synoptic sites in the Kentucky River Basin-Continued

[N, North; Ky, Kentucky; R, River, nr, near; Ck, Creek; M, Middle; S, South]

\begin{tabular}{|c|c|c|c|c|c|}
\hline slte number & Slte name & $\begin{array}{c}\text { Synoptlc } \\
\text { site } \\
\text { code }\end{array}$ & $\begin{array}{c}\text { Dralnage } \\
\text { area, In } \\
\text { square } \\
\text { mlles }\end{array}$ & Latitude' & Longltude $^{1}$ \\
\hline 03282250 & Ky $R$ at Irvine & HA & 3,138 & 374155 & 835832 \\
\hline 03282500 & Red R nr Hazel Green & $\mathrm{HB}$ & 65.8 & 374844 & 832750 \\
\hline 03283200 & Red R at Highway 77 & $\mathrm{HC}$ & 184 & 375000 & 833936 \\
\hline 03283320 & M Fork Red R nr Slade & HD & 25.4 & 374814 & 834233 \\
\hline 03283370 & Cat Ck nr Stanton & $\mathrm{HE}$ & 8.30 & 374955 & 834841 \\
\hline 03283500 & Red R at Clay City & $\mathrm{HF}$ & 362 & 375153 & 835601 \\
\hline 03283815 & Ky R nr Doylesville & IA & 3,771 & 375140 & 840940 \\
\hline 03283820 & Muddy Ck at Elliston & IB & 37.0 & 374427 & 840922 \\
\hline 03283830 & Muddy Ck at Doylesville & IC & 63.8 & 375048 & 840945 \\
\hline 03283990 & Otter Ck at Redhouse & ID & 22.7 & 374947 & 841622 \\
\hline 03284000 & Ky $R$ at Lock 10, Winchester & JA & 3,955 & 375341 & 841544 \\
\hline 03284210 & Tate Ck at Million & JB & 14.4 & 374646 & 842312 \\
\hline 03284225 & Ky R nr Valley View & KA & 4,100 & 375049 & 842608 \\
\hline 03284315 & Silver Ck at Silver Ck & $\mathrm{KB}$ & 68.2 & 373933 & 842146 \\
\hline 03284560 & Hickman Ck nr Mills & $\mathrm{KC}$ & 64.2 & 375332 & 843053 \\
\hline 03284600 & Ky $R$ at Camp Nelson & LA & 4,528 & 374610 & 843703 \\
\hline 03284630 & Town Fork nr Nicholasville & LB & 6.7 & 375049 & 843512 \\
\hline 03284800 & Dix R nr Stanford & LC & 160 & 373318 & 843610 \\
\hline 03285000 & Dix R nr Danville & LD & 318 & 373831 & 844444 \\
\hline 03285200 & Clarks Run nr Danville & LE & 14.9 & 373820 & 844316 \\
\hline 03286500 & Ky R at Lock 7, Highbridge & MA & 5,031 & 374945 & 844326 \\
\hline 03286510 & Ky R nr Highbrigde & NA & 5,036 & 375138 & 844207 \\
\hline 03287000 & Ky R at Lock 6, Salvisa & $\mathrm{OA}$ & 5,102 & 375532 & 844917 \\
\hline 03287130 & Clear Ck nr Mortonsville & OB & 61.6 & 375637 & 844553 \\
\hline 03287248 & Ky R nr Tyrone & PA & 5,222 & 380227 & 845047 \\
\hline 03287300 & Glenns Ck nr Versailles & PB & 19.5 & 380548 & 844802 \\
\hline 03287500 & Ky R at Lock 4, Frankfort & QA & 5,304 & 381206 & 845254 \\
\hline 03287545 & Benson Ck nr Frankfort & QB & 101 & 381229 & 845614 \\
\hline 03287575 & Ky R nr Elkhorn Ck & RA & 5,441 & 381857 & 845113 \\
\hline 03288000 & N Elkhorn Ck nr Georgetown & RB & 119 & 381220 & 843049 \\
\hline 03288150 & N Elkhorn Ck at Great Crossing & $\mathrm{RC}$ & 155 & 381256 & 843621 \\
\hline 03288460 & N Elkhorn Ck nr Frankfort & RD & 276 & 381259 & 844751 \\
\hline
\end{tabular}


Table 2. Location of the synoptic sites in the Kentucky River Basin-Continued

[N, North; Ky, Kentucky; R, River, nr, near, Ck, Creek; M, Middle; S, South]

\begin{tabular}{clcccc}
\hline Site number & \multicolumn{1}{c}{ Slte name } & $\begin{array}{c}\text { Synoptlc } \\
\text { site } \\
\text { code }\end{array}$ & $\begin{array}{c}\text { Drainage } \\
\text { area, in } \\
\text { square } \\
\text { mlles }\end{array}$ & Latitude' & Longitude $^{1}$ \\
\hline 03289000 & S Elkhorn Ck at Fort Spring & RE & 24 & 380235 & 843735 \\
03289195 & Town Branch nr Lexington & RF & 30 & 380429 & 843253 \\
03289300 & S Elkhorn Ck nr Midway & RG & 105 & 380827 & 843843 \\
03289470 & S Elkhorn Ck nr Frankfort & RH & 187 & 381254 & 844756 \\
03289500 & Elkhorn Ck nr Frankfort & RI & 473 & 381607 & 844853 \\
03290500 & Ky R at Lock 2, Lockport & SA & 6,180 & 382620 & 845748 \\
03290600 & Drennon Ck at Delville & SB & 62 & 382839 & 850550 \\
03291130 & Eagle Ck at Lusbys Mill & SC & 174 & 383153 & 844309 \\
03291300 & Eagle Ck at Donningsville & SD & 293 & 383831 & 844246 \\
03291310 & Clarks Ck nr Stewartsville & SE & 9.2 & 383754 & 843730 \\
03291510 & Eagle Ck nr Sanders & SF & 468 & 383900 & 845648 \\
03291600 & Ky R at Carrollton & TA & 6,956 & 384048 & 851117 \\
\hline
\end{tabular}

${ }^{1}$ Degree, minute, and second symbols omitted.

\section{Metals and Other Trace Elements}

The selection of sites for evaluating the spatial distribution of metals and other trace elements in streambed sediments was based on two approaches: (1) random selection of small streams that drain catchments of $6 \mathrm{mi}^{2}$ or less (a total of 372 sites) and (2) systematic selection of sites on the Kentucky River main stem, major tributaries, and other sites representative of specific land and water uses in the basin (a total of 105 sites). Several subdesigns were included in the streambed-sediment study approach to evaluate sources of variance relative to analytical variability, intersite and intrasite variability, differences between sediment-sieving methods, and site-specific relations with streambed sediment data reported by the Kentucky Division of Water. Complete details of sampling-site location, data collection, data analyses, and data storage were published in Porter and others (1995).

\section{Nutrients, Suspended Sediments, and Pesticides}

The seven fixed stations were sampled monthly during the study period (fig. 2), and samples were analyzed to determine concentrations of nutrients and sediment. Mean annual loads and yields of waterquality constituents were estimated at sites where at least 2 years of data had been collected. A total of 75 synoptic sampling sites (fig. 2) were sampled during low-flow conditions in August 1987 and August 1988, when the effects of point-source discharges predominated. Sampling sites for the nutrient and sediment synoptic studies were selected to (1) include sites affected by point-source discharges, (2) include areas where data were largely unavailable, and (3) ensure that the entire reach of the Kentucky River main stem would be assessed at intervals of no more than $50 \mathrm{mi}$. A total of 146 samples were collected during August 24-28, 1987, and August 8-12, 1988. Chlorophyll $a$ concentrations and algal cell densities were also measured at several synoptic sites. The pesticide assessment included multiple 
components. Water and (or) streambed-sediment samples were collected at several sites and analyzed to determine concentrations of hydrophilic pesticides, triazine herbicides, organophosphorus insecticides, and organochlorine compounds. Complete details of data collection, data analyses, and data storage were published in Haag and Porter (1995).

\section{Major lons and Radionuclides}

The seven fixed stations were sampled monthly during April 1987-March 1990 to determine the distribution of major ions and radionuclides (fig. 2). Mean annual loads and yields of major ions and radionuclides were estimated for sites where at least 2 years of data had been collected.

\section{Synthetic Organic Compounds Other Than Pesticides}

The assessment of nonpesticide organic compounds included several components. streambedsediment samples were collected at 13 sites in October 1987 and at 26 sites in November 1988 (fig. 3). Streambed-sediment samples were analyzed by the Tennessee Valley Authority, Laboratory Branch, in Chattanooga, Tenn. Water samples were collected at 10 sites in 1988 and 1989 and analyzed to determine concentrations of nonpesticide organic compounds. Analyses of water samples were done in the USGS National Water Quality Laboratory in Arvada, Colo.

\section{Fecal-Indicator Bacteria}

At three fixed stations in the Kentucky River Basin (Kentucky River at Lock 10, Elkhom Creek near Frankfort, Kentucky River at Lock 2; fig. 2), a surface-water sample was collected monthly for the analysis of fecal-indicator bacteria during April 1987-March 1990. In addition, a sample was collected during the low-flow synoptic investigation of August 8-12, 1988, at each synoptic site (fig. 2; table 2) with the exception of Drennon Creek at Delville (SB) and Eagle Creek at Donningsville (SD). Where possible, depth-integrated samples were collected in sterile 1-liter polyethylene bottles (Ward and Harr, 1990). If the stream was too shallow to depth integrate, a midstream grab sample was collected with a sterile bottle. The sample was transferred to a cooler, maintained in ice at $4^{\circ} \mathrm{C}$ or less, and analyzed within 6 hours. Samples from fixed sites and nearly half the samples collected at synoptic sites were tested for fecal-coliform and fecal-streptococcus bacteria according to standard membrane-filtration techniques described by Britton and Greeson (1987). All synoptic investigation samples were tested for Escherichia coli $(E$. coli) by use of the species-specific m-tec procedure (Dufour and others, 1981; U.S. Environmental Protection Agency, 1985a).

Water samples were collected by the Kentucky Natural Resources and Environmental Protection Cabinet (KNREPC), Division of Water (KDOW), at 11 sites during 1980-90 and were analyzed to determine counts of fecal-indicator bacteria. These data are included for purposes of comparison and to provide a longer period of record from which temporal trends can be determined.

\section{Dissolved Oxygen}

Two sampling programs were used to assess dissolved-oxygen (DO) concentrations in the Kentucky River Basin. Water samples were collected monthly at the seven fixed stations during April 1987March 1990. The fixed station sampling program was designed to assess average DO concentrations and variability during the 3-year period. A total of 333 samples were collected at approximately monthly intervals. Water samples were also collected once per year for 2 consecutive years at 75 synoptic sites. Sampling sites for the DO synoptic studies were selected to (1) evaluate locations were significant DO depletion was likely, during low flow (and high temperature) periods, (2) include areas where data were 


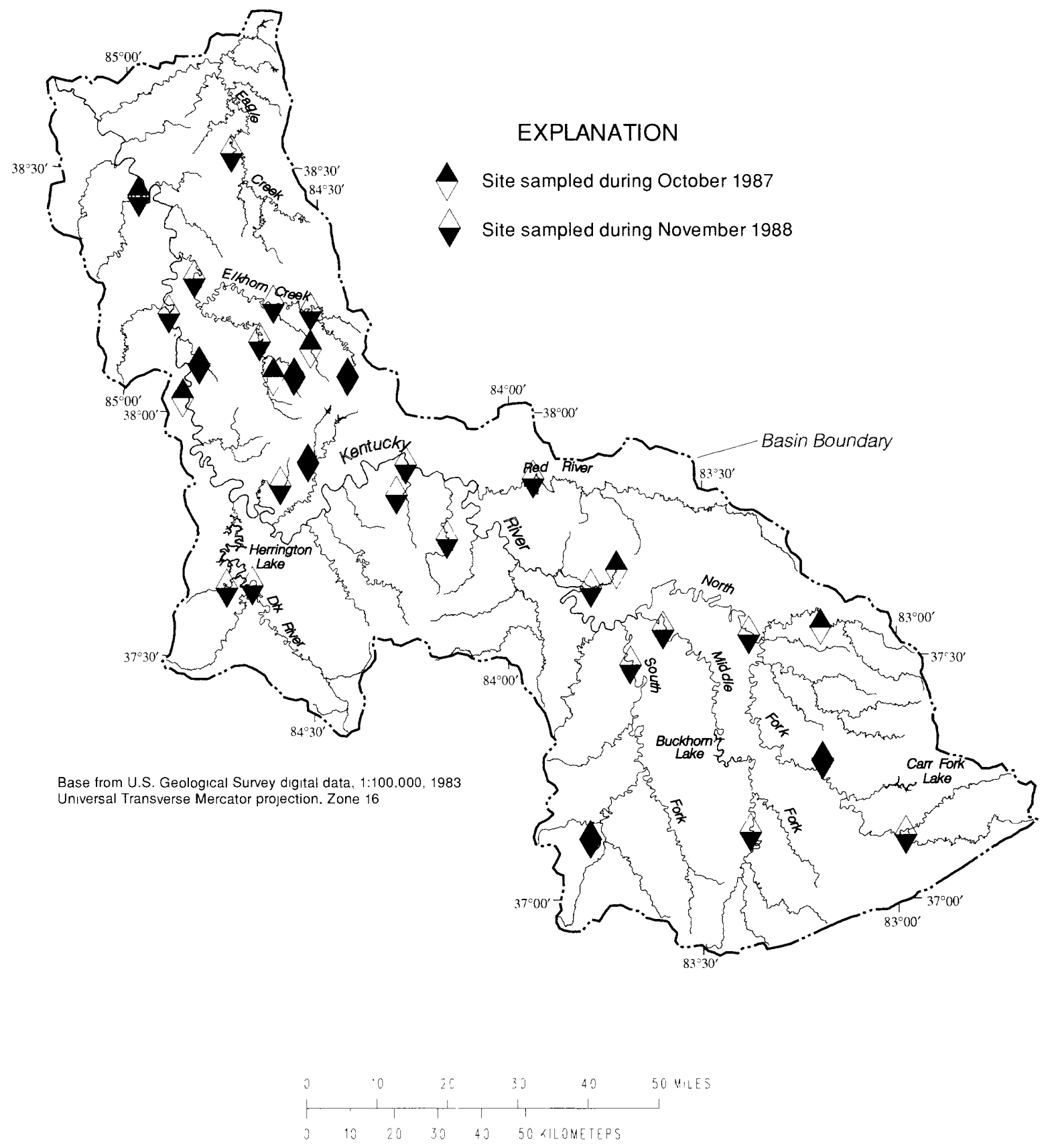

Figure 3. Location of streambed-sediment sites sampled for nonpesticide organic compounds in October 1987 and November 1988 in the Kentucky River Basin. 
largely unavailable, and (3) ensure that the entire reach of the Kentucky River main stem would be assessed at intervals of no more than $50 \mathrm{mi}$. An analysis of the fixed-station and synoptic data provides a comprehensive view of DO conditions in the Kentucky River Basin during 1987-90.

Water samples for DO analysis were collected with a sewage sampler in a low-velocity section of the channel. A peristaltic pump was used to collect the sample where stream depth was less than $2 \mathrm{ft}$ (Griffin and others, 1994). Samples were depth-integrated at a single point. Analyses were performed using the Winkler method (American Public Health Association, 1987).

Exploratory data-analysis techniques (EDA) (Tukey 1977; Chambers and others, 1983) were used to assess the DO data. These techniques are useful for developing hypotheses and for explaining patterns, trends, and relations in the data. However, EDA techniques are not confirmatory techniques and do not allow for valid testing of the hypotheses. Many graphical methods were used to explore the data, including boxplots, histograms, and smoothed scatterplots. The data were subsetted to reduce variability and to ascertain the principal factors influencing changes in DO concentrations. Multiple-regression models used in combination with $\mathrm{K}$-means cluster analysis, distance-weighted least-squares regression, and casement plots (Chambers and others, 1983) proved to be the most useful techniques.

Water samples for DO analysis were collected with a sewage sampler in a low-velocity section of the channel. A peristaltic pump was used to collect the sample where stream depth was less than $2 \mathrm{ft}$ (Griffin and others, 1994). Samples were depth-integrated at a single point. Analyses were done using the Winkler method (American Public Health Association, 1987).

\section{Quality Assurance and Quality Control}

The guidelines for quality assurance and quality control (QA/QC) in the NAWQA program are outlined in Mattraw and others (1989). Specific QA/QC procedures in practice during the Kentucky River Basin pilot study are described by Griffin and others (1994). Analytical laboratory QA/QC practices that were used are detailed by Friedman and Erdmann (1983) and Fishman and Friedman (1989). The USGS National Water Quality Laboratory quality-assurance practices are described by Jones (1987).

\section{RESULTS OF INVESTIGATIONS OF SURFACE-WATER QUALITY}

\section{Effects of Oil Production}

Production of oil is an important activity in parts of the Kentucky River Basin lying within the Knobs Region, averaging 1.6 million bbl $^{1}$ per year from 1982 through 1987 (Evaldi and Kipp, 1991). Oil is produced mainly from stripper wells, which are defined as those that produce less than $10 \mathrm{bbl}$ of oil per day. About $10 \mathrm{bbl}$ of brine are produced along with each barrel of oil produced. Discharge of this brine to streams and injection of freshwater or a mixture of freshwater and brine into the oil-production units for enhanced oil recovery are common practices. Discharge of brine from oil separators is suspected as a major source of dissolved constituents to streams draining oil-production areas (Evaldi and Kipp, 1991). Complete details of the study of the effects of oil production on the water resources in the Kentucky River Basin were published by Evaldi and Kipp (1991). A brief summary of the major findings is presented in this report.

\footnotetext{
${ }^{1} \mathrm{~A}$ barrel (bbl) is defined as 42 standard U.S. gallons.
} 
Surface water from Cat Creek Subbasin, a non-oil-producing subbasin, was a calcium bicarbonate type except about 10 percent of the time when chloride became the dominant anion and specific conductance increased. Calcium and carbonates (carbonate plus bicarbonate) were the predominant dissolved constituents transported from the non-oil-producing subbasin; chloride comprised less than 5 percent and bromide less than 0.01 percent of the annual dissolved-constituent transport. Annual yields of bromide and chloride from the non-oil-producing subbasin during April 1987-March 1989 were 0.08 and 19 ton/mi ${ }^{2}$, respectively.

Oil-production activities were the source of barium, boron, bromide, chloride, magnesium, sodium, and strontium in the Big Sinking Creek and Furnace Fork Subbasins. Chloride concentrations in Fumace Fork exceeded the Kentucky criterion of $600 \mathrm{mg} / \mathrm{L}$ for protection of aquatic habitats about 3 percent of the time. Chloride concentrations in Big Sinking Creek exceeded the $600-\mathrm{mg} / \mathrm{L}$ criterion more than 40 percent of the time. Concentrations of organic compounds in water of all three subbasins were similar to one another during the study period.

Dissolved-constituent loads in runoff from the oil-producing subbasins and the non-oil-producing subbasin had a similar non-uniform loading pattern, an indication of intermittent release. Assuming that oil production is relatively constant, constituent-transport pulses are a function of both streamflow and time since the system was last flushed. Comparatively little constituent transport occurs during low flows in summer and fall even though constituent concentrations are greatest at that time. During high flows, the concentrations are low, but the loads are high. The greatest transport usually occurs during initial highflow storms following the low-flow season.

The average annual yields of bromide, chloride, sodium, and strontium in the Big Sinking Creek Subbasin were at least 10 times greater than from the non-oil-producing Cat Creek Subbasin. The average daily chloride loads of Fumace Fork and Big Sinking Creek were much higher than that allowed by State permits for discharge of oil-production brines to streams. The average brine-related chloride load of Big Sinking Creek was approximately $34,000 \mathrm{lb} / \mathrm{d}$, but a total chloride load of only slightly more than $2,000 \mathrm{lb} / \mathrm{d}$ is permitted.

Overall, oil-producing subbasins in the Kentucky River Basin contribute a high percentage of the dissolved-constituent loads of the Kentucky River. During April 1987 to March 1989, the average annual bromide and chloride loads in the Kentucky River at Lock 10 were approximately 265 tons and 72,600 tons, respectively. The two oil-producing subbasins studied, which drain only 0.84 percent of the area upstream from Lock 10, contributed 10.3 percent of the chloride load and 22.5 percent of the bromide load at Lock 10.

There appears to be a positive correlation between oil production in the Kentucky River Basin and bromide load in the Kentucky River downstream from the oil producing areas of the basin. However, additional information is needed on oil-production activities to further refine and quantify this relation.

\section{Metals and Other Trace Elements}

A complete discussion of the character and distribution of metals and trace elements in the Kentucky River Basin was published in Porter and others (1995). A brief summary of the major findings of their study is presented in this report.

The spatial distribution of metals and other trace elements in streambed sediments in the Kentucky River Basin is the result of regional differences in geology, land use and cover, and human activities. Soils and streambed sediments derived from geologic materials in the Eastem Coal Field contain high 
concentrations of aluminium, iron, and titanium, whereas soils and streambed sediments in the Knobs Region contain high concentrations of chromium, copper, lead, nickel, and vanadium. In the Bluegrass Region, soils and streambed sediments contain high concentrations of calcium, phosphorus, strontium, and yttrium. Land disturbance, such as coal mining and agricultural activities, exposes geologic materials to weathering; the result is accelerated transport of sediment by streams in the region and increases in trace elements similar to those indicated for the bedrock types within a physiographic region.

Streambed-sediment concentrations of potentially toxic metals are large in urban and industrial areas of the basin. Concentrations of arsenic, barium, chromium, iron, lead, manganese, nickel, and zinc in streambed sediments in the Kentucky River Basin equaled or exceeded the USEPA's "heavily polluted" classification. Concentrations of lead and zinc were high in streambed sediments of the urbanized Inner Bluegrass Region and likely were derived from urban stormwater runoff, point-source discharges, and waste-management practices. Concentrations of cadmium, chromium, copper, mercury, and silver were high in streambed sediments of streams that received WWTP discharges. Concentrations of barium, chromium, and lithium in streambed sediment were elevated in streams that received brine discharges from oil production. High concentrations of antimony, arsenic, molybdenum, selenium, strontium, uranium, and vanadium in streambed sediments were generally associated with geologic sources rather than human activities.

Concentrations of dissolved metals and other trace elements at fixed stations in the Kentucky River Basin are a function of discharge and site-specific physicochemical conditions. Although total concentrations (total recoverable and dissolved) of some metals and other trace elements are high in streams affected by land disturbance, concentrations of constituents in suspended sediment are higher in streams that receive drainage from the Knobs Region or in streams that receive wastewater or oil-wellbrine discharges. Total-recoverable and suspended-sediment-fraction concentrations of many metals and trace elements were lower during low-flow conditions, such as the extended drought of 1987-88, than during medium or high flows.

Total-recoverable concentrations of aluminium, beryllium, cadmium, chromium, copper, iron, manganese, nickel, silver, and zinc exceeded water-quality criteria established by the USEPA or the KDOW at one or more fixed sites in the Kentucky River Basin during 1987-90. Concentrations of aluminium, iron, and manganese frequently exceeded established criteria during periods of high flow at most fixed sites. Concentrations of copper, lead, and silver occasionally exceeded acute or chronic aquaticlife criteria at many fixed sites. Concentrations of nickel exceeded the Kentucky domestic water-supply source criterion in 25 percent of samples from the Kentucky River. Acute or chronic aquatic-life criteria for total-recoverable concentrations of beryllium, cadmium, chromium, and zinc were exceeded by 2 to 15 percent of water-quality samples from the North Fork Kentucky River at Jackson and the Kentucky River at Lock 10. Kentucky water-quality criteria for antimony, arsenic, barium, boron, cobalt, lithium, mercury, selenium, or thallium were not exceeded in water samples collected from the fixed sites during 1987-90.

Significant upward trends in the total-recoverable concentrations of aluminium, iron, magnesium, manganese, and zinc were indicated at one or more fixed stations in the Kentucky River Basin since the mid-1970's or early 1980's. Upward trends for concentrations of aluminum, iron and manganese were significant at sites that receive drainage from coal mines in the upper Kentucky River Basin. Downward trends in the concentration of barium and boron are possibly related to similar trends for stream discharge at the fixed stations in the Kentucky River Basin. 


\section{Nutrients, Sediments, and Pesticides}

Haag and Porter (1995) published a detailed discussion of the spatial distribution of nutrients, sediments, and pesticides in the Kentucky River Basin. A brief summary of historical data and the major findings of the NAQWA project are presented below.

The enrichment of streams with nutrients, specifically phosphorus and nitrogen, is a priority waterquality issue in the Kentucky River Basin. Concentrations of total phosphorus ranged from 10 to $3,700 \mu \mathrm{g} / \mathrm{L}$ in 251 water samples collected in the basin during 1971-86 (Smoot and others, 1991). Highest total phosphorus concentrations were found in streams receiving sewage effluent. High total phosphorus concentrations were also found throughout the Bluegrass Region, which is underlain by phosphatic limestone (Smoot and others, 1991). Spatially, total phosphorus concentrations increase steadily from the headwater reaches to the river mouth, but no temporal trends were evident from the available data. The phosphorus content of soils in the Inner Bluegrass Region (>150 mg/kg) promotes growth of nitrogen-fixing plants, which are responsible in part for relatively high ambient nitrogen concentrations. Available data for 1979-86 indicate a slightly increasing trend in total nitrogen concentrations from the headwaters to the mouth of the river. Generally, nutrient concentrations at the fixed stations did not differ significantly among years. Concentrations of total ammonia plus organic nitrogen ranged from less than 0.2 to $3.4 \mathrm{mg} / \mathrm{L}$ at these stations, whereas concentrations of dissolved nitrite plus nitrate nitrogen ranged from less than 0.01 to $8.5 \mathrm{mg} / \mathrm{L}$. Total phosphorus concentrations ranged from less than 0.01 to $5.7 \mathrm{mg} / \mathrm{L}$. At the Elkhorn Creek station, however, concentrations of total phosphorus and total nitrogen appeared to be higher in 1987 than in the other years.

Estimated loads of total phosphorus at the fixed stations were relatively low in the upper end of the basin, ranging from $32.6 \mathrm{ton} / \mathrm{yr}$ in the Middle Fork of the Kentucky River at Tallega to 94.2 ton/yr in the North Fork of the Kentucky River at Jackson. Total phosphorus loads were an order of magnitude higher (1,920 ton/yr) at the most downstream site (Kentucky River at Lock 2). Estimated loads of dissolved nitrite plus nitrate nitrogen ranged from 192 ton/yr in the Middle Fork of the Kentucky River at Tallega to 9,170 ton/yr in the Kentucky River at Lock 2. Estimated yields of total phosphorus and dissolved nitrite plus nitrate nitrogen were highest for Elkhom Creek at Frankfort (0.95 and 5.32 (ton/ $\left./ \mathrm{mi}^{2}\right) / \mathrm{yr}$, respectively) because of the effect of WWTP effluents.

Although there were no statistically significant correlations between nutrient concentrations and streamflow, high total phosphorus concentrations were generally found at high streamflow in rural (nonurban) areas where nonpoint-source runoff occurred. High total nitrogen concentrations were found at the upper and the lower extremes of streamflow in the lower part of the basin near the mouth of the Kentucky River, reflecting the effect of point sources and nonpoint sources of constituents. Significant correlations were found between concentrations of total phosphorus and suspended sediment. At many sampling sites in urban areas, most of the stream nitrogen load was attributable to WWTP effluent, even when only a small proportion of the total streamflow consisted of WWTP effluent. In stream nitrogen concentrations at synoptic sites downstream from WWTP's were among the highest measured in the Kentucky River Basin. For example, concentrations of dissolved nitrite plus nitrate nitrogen exceeded $10.0 \mathrm{mg} / \mathrm{L}$ in Hickman Creek near Mills and in Clark's Creek near Stewartsville in August 1987 and in Town Branch near Lexington in August 1988.

Significant correlations between land-use type and concentrations of nitrogen forms were not found at the fixed stations. Concentrations of phosphorus, however, were positively correlated with urban and agricultural land use, and negatively correlated with forest and mining land use. The high phosphorus content of soils in the Inner and Outer Bluegrass Regions presumably contributes to concentrations of 
phosphorus in streams of these physiographic regions. No correlations between nutrients and land-use type were indicated at the synoptic sites, although high concentrations of phosphorus were also found in areas where urban or agricultural land use predominated.

Phytoplankton chlorophyll $a$ concentrations in the Kentucky River main stem during low-flow conditions correlated positively with concentrations of total phosphorus and total ammonia plus organic nitrogen. The positive correlation of chlorophyll $a$ with total ammonia plus organic nitrogen indicates that a considerable proportion of total nitrogen was transported as algal biomass during periods of low discharge. The highest algal cell densities and the highest concentrations of chlorophyll $a$ were found in the lower Kentucky River, downstream from river mile 180. In tributary streams, phytoplankton chlorophyll $a$ concentrations also correlated positively with concentrations of total phosphorus and total ammonia plus organic nitrogen. In August 1987 and 1988, several streams affected by urban sources of nutrient enrichment contained relatively low concentrations of phytoplankton chlorophyll $a$, an indication that periphyton probably dominated the algal community in those streams. Streams affected by agricultural sources of nutrients contained relatively higher densities of phytoplankton than did streams that drained forested subbasins. Median concentrations of chlorophyll $a$ and algal cell density were significantly lower in streams that drained surface-mined areas than in streams that drained agricultural and urban lands.

In the Kentucky River Basin, suspended-sediment concentrations ranged from less than 1.0 to $18,000 \mathrm{mg} / \mathrm{L}$ in surface-water samples collected during 1979-86 (Smoot and others, 1991). More than 90 percent of the suspended sediment in the basin is silt and clay (Flint, 1983). There are about 1,070 $\mathrm{mi}^{2}$ of disturbed land in the basin and $1,700 \mathrm{mi}$ of excessively eroding streambanks and roadbanks contributing to stream sediment loads. Such sources have noticeably degraded ahout 30 percent of the streams capable of supporting a sport fishery in the basin. Decreases in suspended-sediment concentrations were noted at 7 of 11 sites during 1976-86 (Smoot and others, 1991). This decrease may reflect the recent adoption of no-tillage practices for tobacco, com, and soybeans, which are the major crops in the basin. Stream reaches draining areas disturbed by mining and the associated deforestation contained higher suspended-sediment concentrations than streams in areas devoted to pasture and rowcrop agriculture.

Median suspended-sediment concentrations during April 1987-March 1990 ranged from 18 to $31 \mathrm{mg} / \mathrm{L}$ at the main-stem sites. The maximum suspended-sediment concentration in the study area was found in the Kentucky River at Jackson $(1,780 \mathrm{mg} / \mathrm{L})$ - an area where mining activities are a predominant land use. The minimum median concentration of suspended sediment at a fixed station was found in Elkhorn Creek at Frankfort $(10 \mathrm{mg} / \mathrm{L})$. The trend in suspended-sediment concentrations decreased downstream in the Kentucky River main stem from the headwaters to the mouth during the study. Suspended-sediment concentrations correlated with discharge at the fixed sites; concentrations were always lower in summer, which is typically a low-flow period, than in any other season of the year. No significant correlations were found between suspended-sediment concentrations and any nutrient forms in the Kentucky River Basin, with the exception of phosphorus. No correlations were found between land use and total suspended-sediment concentrations, although the level of resolution of land-use data may not have been adequate to reflect differences at the subbasin scale. A significant 15-year downward flowadjusted trend for suspended-sediment concentrations was indicated for the Kentucky River at Lock 2 . The downward trend may have resulted from the implementation of best-management practices to reduce soil erosion from surface-mining and agricultural activities in the Kentucky River Basin.

Herbicide and insecticide use has increased in recent years in the Kentucky River Basin (Gianessi, 1986). In the compiled data base for 1976-86, only one analysis of a water sample for herbicides was found. Of the three target analytes in that sample, 2,4,5-T and 2,4-D were detected, but silvex was not. In the Kentucky River Basin, atrazine and butylate together account for more than half of all herbicide used (Smoot and others, 1991); however, analyses for these and other common herbicides in water samples 
collected prior to 1986 are not available. Organochlorine insecticides, including benzene hexachloride, chlordane, lindane, dieldrin, $\mathrm{P}, \mathrm{P}^{\prime}$-DDD, and $\mathrm{P}, \mathrm{P}^{\prime}$-DDE, were detected in numerous samples of stream sediment and fish tissue collected during 1976-86 (Smoot and others, 1991). Analyses for organophosphorus insecticides were limited to two samples in which no detectable concentrations were found.

Atrazine was found in water samples at sites throughout the Kentucky River Basin. Concentrations of triazine herbicides rarely exceeded $0.5 \mu \mathrm{g} / \mathrm{L}$, but water samples collected in June 1989 from North Elkhorn Creek at Georgetown contained unusually high concentrations of atrazine $(16.0 \mu \mathrm{g} / \mathrm{L})$ and simazine $(4.5 \mu \mathrm{g} / \mathrm{L})$. Other herbicides frequently found were 2,4-D, alachlor, metolachlor, and dicamba. Diazinon, malathion, and parathion were the most frequently detected organophosphate insecticides in water samples, particularly in the Elkhorn Creek Basin. At two sites, concentrations of pesticides in water samples exceeded the Maximum Contaminant Levels (MCL's) of USEPA Drinking Water Regulations (atrazine in North Elkhom Creek at Georgetown) and acute and chronic aquatic life criteria (malathion and parathion in South Elkhom Creek at Midway).

Analyses of streambed-sediment samples collected during April 1987-March 1990 resulted in frequent detections of several organochlorine insecticides, including aldrin, chlordane, DDT, DDE, dieldrin, endrin, endosulfan, heptachlor, heptachlor epoxide, and lindane. Chlordane was found at concentrations ranging from 59.4 to $269 \mu \mathrm{g} / \mathrm{kg}$ in Hickman Creek, Town Fork, Town Branch, Glenns Creek, and North Elkhom Creek. Many of the detections of pesticides in the Kentucky River Basin were in counties of the Bluegrass Region, where agricultural land use is dominant. Data indicated that residential pesticide application in urban areas in the Bluegrass Region might also affect the distribution of pesticides such as 2,4-D and diazinon in streams.

\section{Major lons and Radionuclides}

Median concentrations of dissolved calcium were highest in Elkhom Creek at Frankfort and lowest in the Middle and South Forks of the Kentucky River, compared to the other fixed stations (table 3).

Maximum calcium concentrations were found in Elkhom Creek at Frankfort. Calcium loads were high in the North Fork Kentucky River at Jackson (table 4), possibly as a result of disturbances of calcium-bearing overburden during surface mining. Dissolved-calcium loads increased downstream to a maximum in the Kentucky River at Lock 2. Compared to the other fixed stations, dissolved-calcium yields were highest in Elkhorn Creek at Frankfort; agriculture and urban development in this subbasin result in disturbance of

calcium-rich limestone deposits, which then contribute annual yields of dissolved calcium $\left(96.8 \mathrm{ton} / \mathrm{mi}^{2}\right)$ that are more than twice that of the Kentucky River at Lock 2. Dissolved-sodium concentrations ranged from 1.7 to $93 \mathrm{mg} / \mathrm{L}$ at the fixed stations. Median concentrations were high in the North Fork Kentucky River at Jackson (13 mg/L) and in Elkhorn Creek at Frankfort $(17 \mathrm{mg} / \mathrm{L})$. Dissolved-potassium concentrations ranged from 1.2 to $10 \mathrm{mg} / \mathrm{L}$, and median concentrations were highest in the North Fork Kentucky River at Jackson (3.1 mg/L) and in Elkhom Creek at Frankfort (3.3 mg/L), compared to the other fixed stations. At the fixed stations, mean annual loads of dissolved sodium and potassium were highest in the Kentucky River at Lock 2, whereas mean annual yields were highest in Elkhorn Creek at Frankfort. 


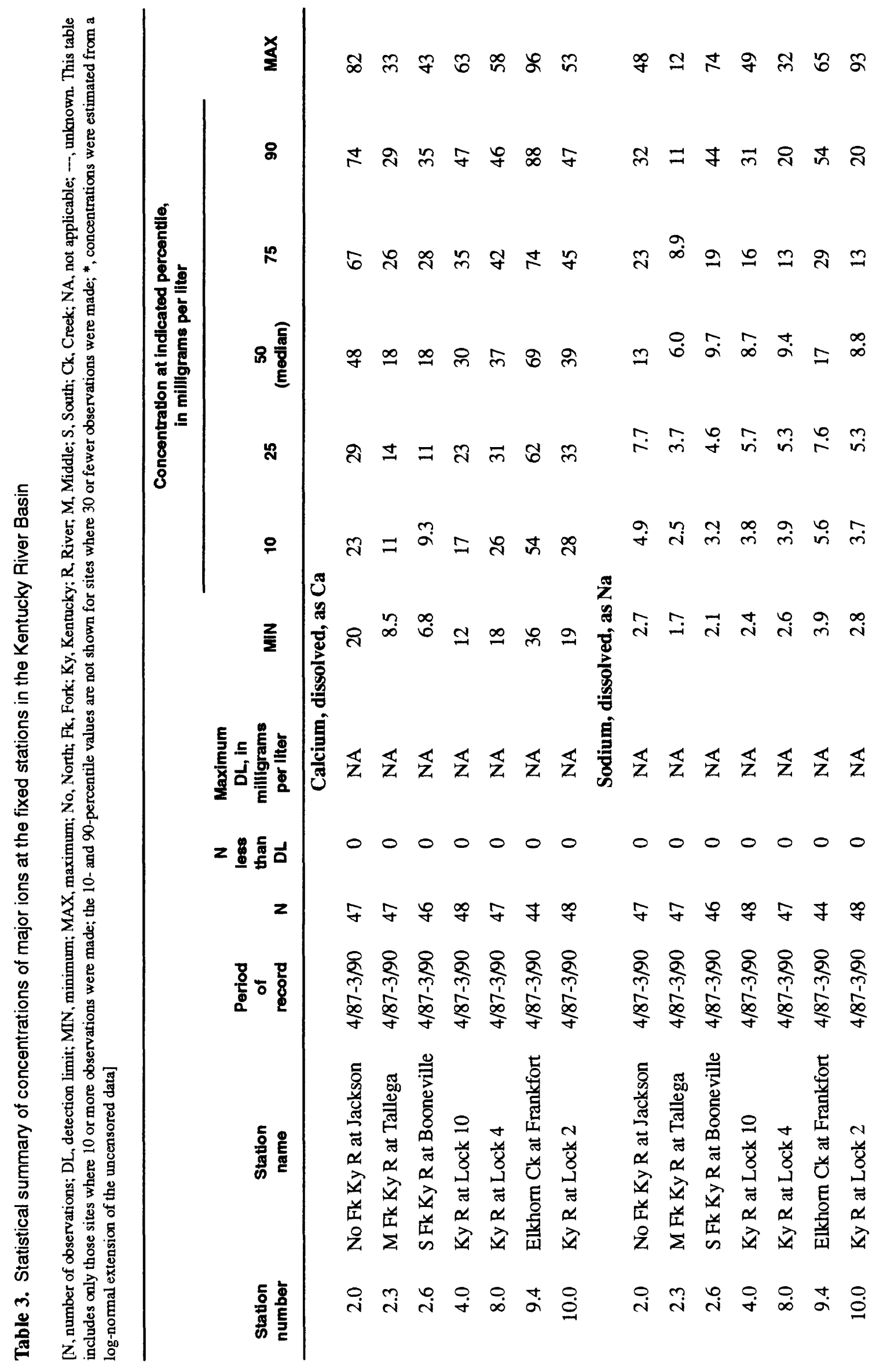




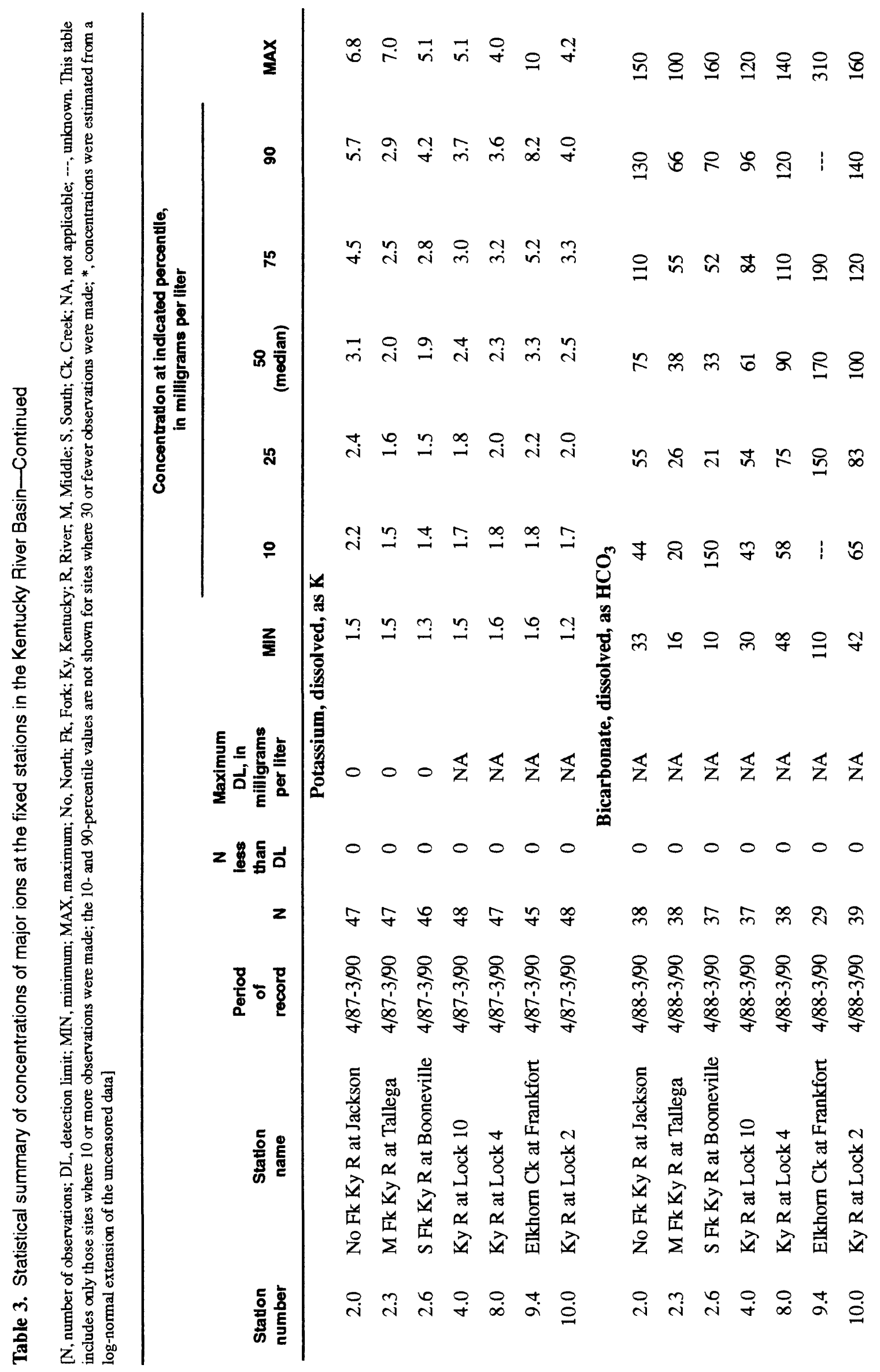

22 Water-Quality Assessment of the Kentucky Rlver Basin, Kentucky:

Results of Investlgations of Surface-Water Quallty, 1987-90 


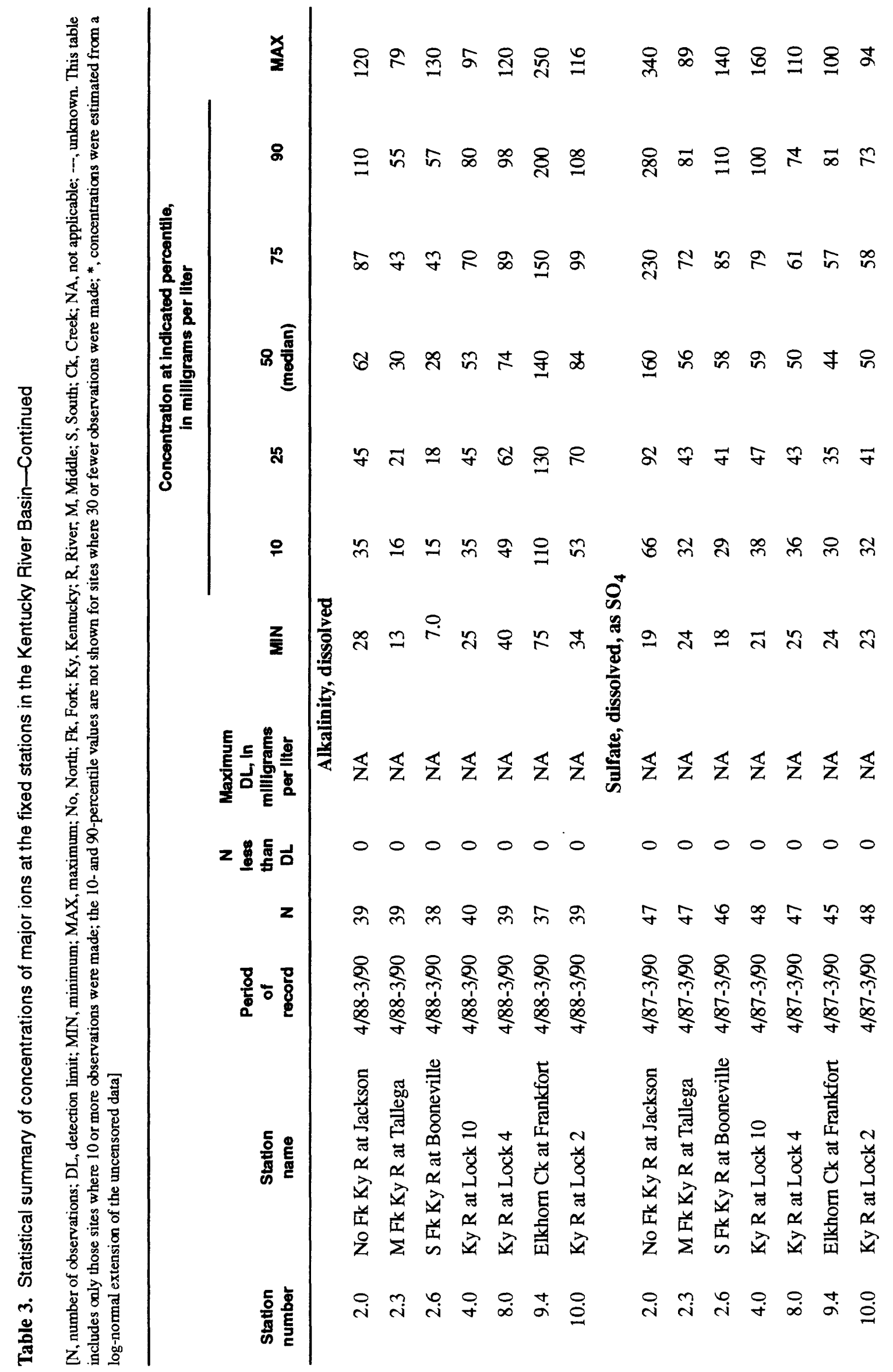




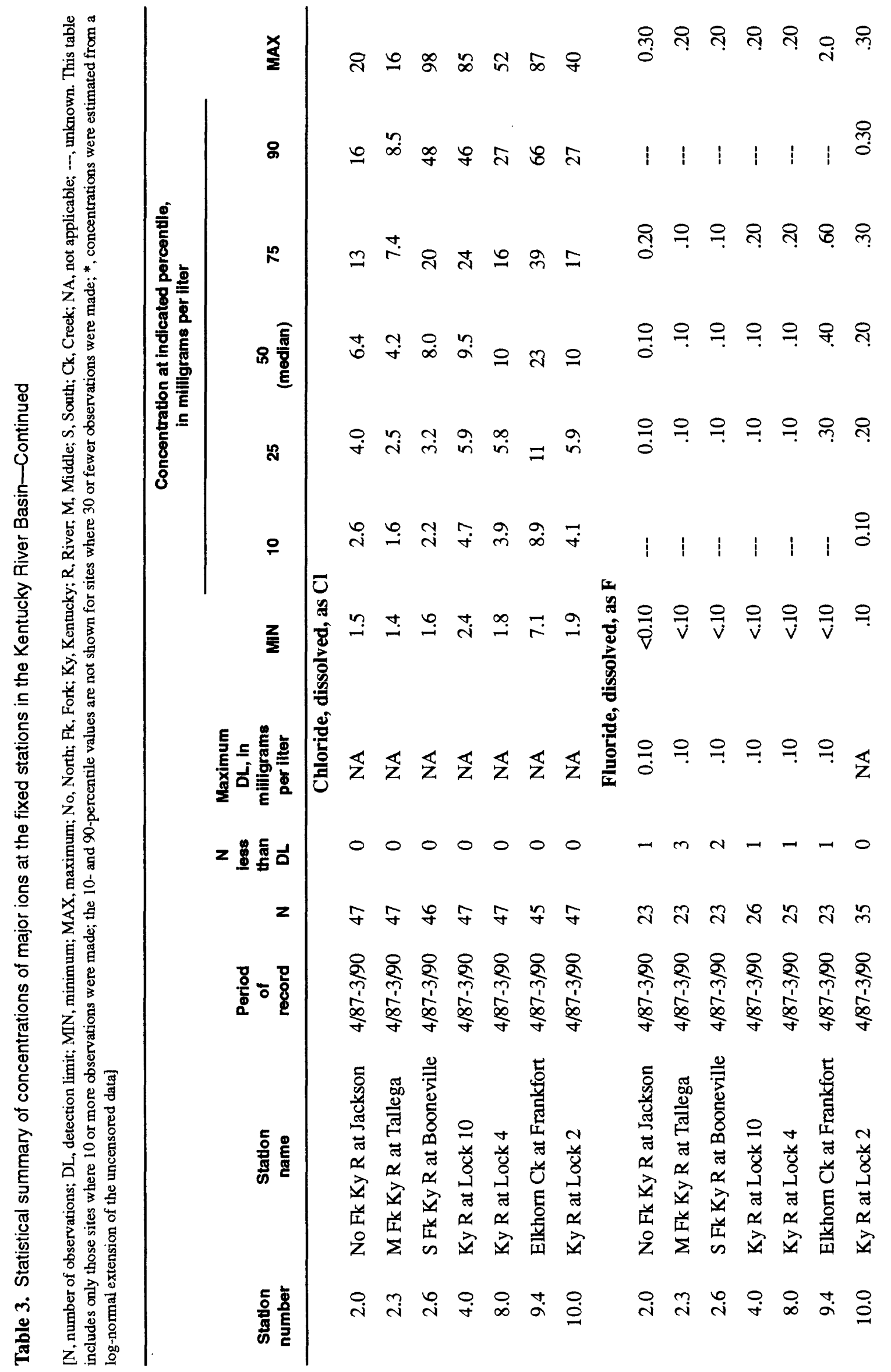




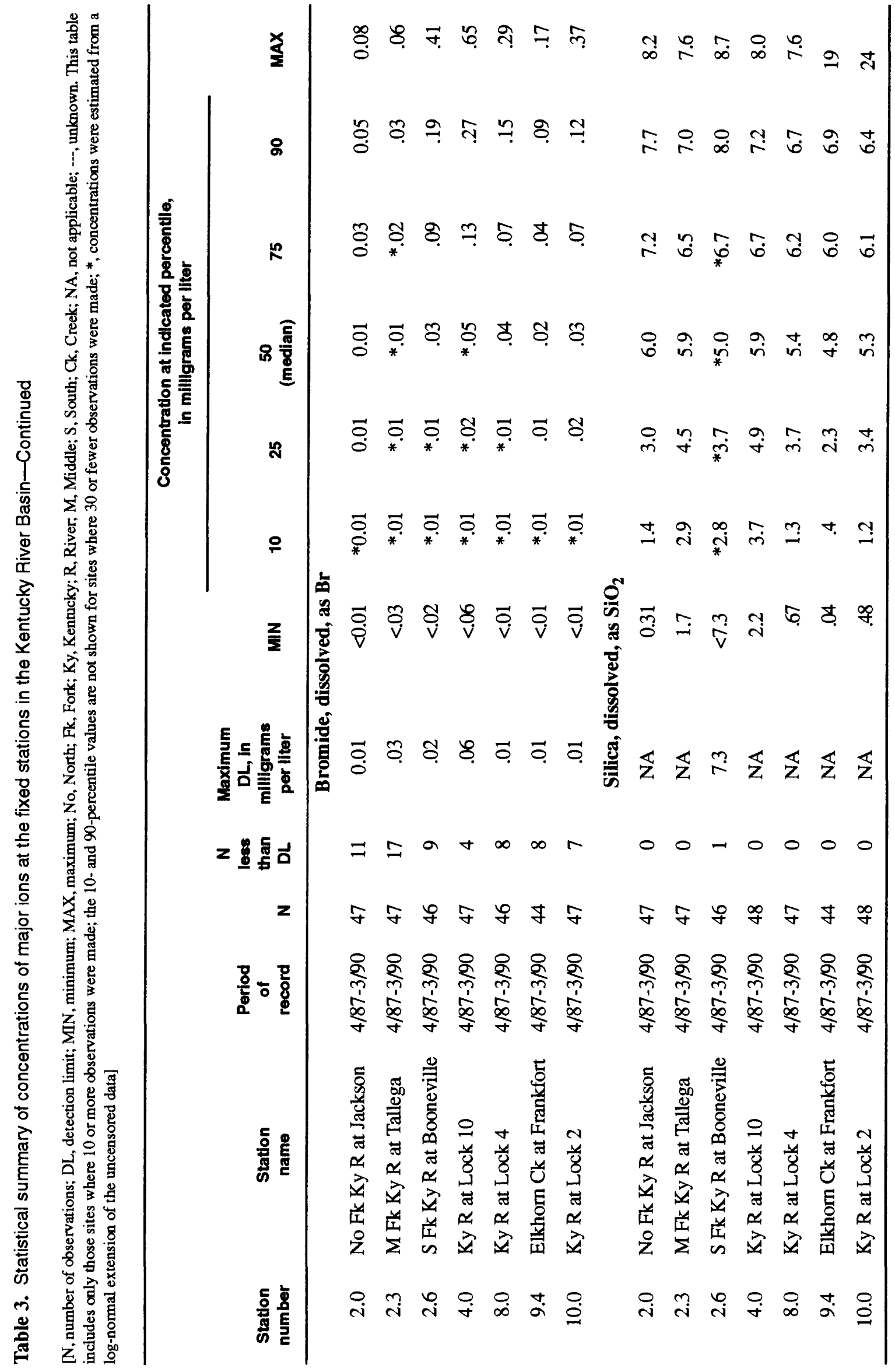


Table 4. Estimated loads and yields of major ions at the fixed stations in the Kentucky River Basin, April 1987-March 1990

[N, number of observations; DL, detection limit; <, less than; No, North; Fk, Fork; Ky, Kentucky; R, River, nr, near; M, Middle; S, South; Ck, Creek]

\begin{tabular}{|c|c|c|c|c|c|c|c|c|}
\hline \multirow[b]{2}{*}{$\begin{array}{l}\text { Station } \\
\text { number }\end{array}$} & \multirow[b]{2}{*}{$\begin{array}{c}\text { Station } \\
\text { name }\end{array}$} & \multirow{2}{*}{\multicolumn{2}{|c|}{$\begin{array}{c}N \\
\text { less } \\
\text { than } \\
D L\end{array}$}} & \multicolumn{2}{|c|}{$\begin{array}{l}\text { Estimated loads } \\
\text { and yields }\end{array}$} & \multicolumn{3}{|c|}{ Uncertainty factors, In percent } \\
\hline & & & & $\begin{array}{l}\text { Mean } \\
\text { annual } \\
\text { load, } \\
\text { in tons }\end{array}$ & $\begin{array}{l}\text { Mean } \\
\text { annual } \\
\text { yleld, } \\
\text { In tons } \\
\text { per } \\
\text { square } \\
\text { mlle }\end{array}$ & $\begin{array}{l}\text { Standard } \\
\text { error of } \\
\text { regression }\end{array}$ & $\begin{array}{c}\text { Flow } \\
\text { duration } \\
\text { of } \\
\text { greatest } \\
\text { sampled } \\
\text { discharge }\end{array}$ & $\begin{array}{l}\text { Proportion } \\
\text { of load } \\
\text { estimate } \\
\text { beyond } \\
\text { range of } \\
\text { sampled } \\
\text { dlscharge }\end{array}$ \\
\hline
\end{tabular}

Calcium, dissolved, as $\mathrm{Ca}$

$\begin{array}{rlrlccccl}2.0 & \text { No Fk Ky R nr Jackson } & 47 & 0 & 47,800 & 43.4 & 13.1 & <0.05 & 0 \\ 2.3 & \text { M Fk Ky R at Tallega } & 47 & 0 & 11,200 & 20.9 & 19.7 & .2 & 1.05 \\ 2.6 & \text { S Fk Ky R at Booneville } & 46 & 0 & 12,700 & 17.6 & 15.2 & .3 & 3.66 \\ 4.0 & \text { Ky R at Lock 10 } & 48 & 0 & 142,000 & 35.8 & 24.1 & <.05 & 0 \\ 8.0 & \text { Ky R at Lock 4 } & 47 & 0 & 241,000 & 44.5 & 19.9 & <.05 & 0 \\ 9.4 & \text { Elkhorn Ck at Frankfort } & 44 & 0 & 45,800 & 96.8 & 15.2 & .3 & 6.59 \\ 10.0 & \text { Ky R at Lock 2 } & 49 & 0 & 290,000 & 46.9 & 19.3 & <.05 & 0 \\ & & & \text { Sodium, dissolved, as Na } & & & \\ 2.0 & \text { No Fk Ky R nr Jackson } & 47 & 0 & 12,400 & 11.3 & 17.2 & <0.05 & 0 \\ 2.3 & \text { M Fk Ky R at Tallega } & 47 & 0 & 3,140 & 5.85 & 28.5 & .2 & .947 \\ 2.6 & \text { S Fk Ky R at Booneville } & 46 & 0 & 6,040 & 8.36 & 35.6 & .3 & 2.15 \\ 4.0 & \text { Ky R at Lock 10 } & 48 & 0 & 42,700 & 10.8 & 41.1 & <.05 & 0 \\ 8.0 & \text { Ky R at Lock 4 } & 47 & 0 & 51,000 & 9.4 & 38.4 & <.05 & 0 \\ 9.4 & \text { Elkhorn Ck at Frankfort } & 44 & 0 & 6,420 & 13.6 & 29.9 & .3 & 2.38 \\ 10.0 & \text { Ky R at Lock 2 } & 49 & 0 & 54,800 & 8.86 & 38.7 & <.05 & 0 \\ & & & \text { Potassium, dissoived, as K } & & & \\ 2.0 & \text { No Fk Ky R nr Jackson } & 47 & 0 & 3,750 & 3.40 & 18.9 & <0.05 & 0 \\ 2.3 & \text { M Fk Ky R at Tallega } & 47 & 0 & 1,490 & 2.78 & 23.7 & .2 & 1.27 \\ 2.6 & \text { S Fk Ky R at Booneville } & 46 & 0 & 1,820 & 2.52 & 17.5 & .3 & 5.84 \\ 4.0 & \text { Ky R at Lock 10 } & 48 & 0 & 12,300 & 3.10 & 14.6 & <.05 & 0 \\ 8.0 & \text { Ky R at Lock 4 } & 47 & 0 & 16,300 & 3.01 & 12.2 & <.05 & 0 \\ 9.4 & \text { Elkhorn Ck at Frankfort } & 45 & 0 & 1,730 & 3.66 & 26.4 & .3 & 5.19 \\ 10.0 & \text { Ky R at Lock 2 } & 49 & 0 & 18,800 & 3.05 & 16.2 & <.05 & 0\end{array}$


Table 4. Estimated loads and yields of major ions at the fixed stations in the Kentucky River Basin, April 1987-March 1990-Continued

IN, number of observations; DL, detection limit; <, less than; No, North; Fk, Fork; Ky, Kentucky; R, River, nr, near; M, Middle; S, South; Ck, Creek]

\begin{tabular}{|c|c|c|c|c|c|c|c|c|}
\hline \multirow[b]{2}{*}{$\begin{array}{l}\text { Station } \\
\text { number }\end{array}$} & \multirow[b]{2}{*}{$\begin{array}{c}\text { Station } \\
\text { name }\end{array}$} & & \multirow[b]{2}{*}{$\begin{array}{l}\text { N } \\
\text { less } \\
\text { than } \\
\text { DL }\end{array}$} & \multicolumn{2}{|c|}{$\begin{array}{l}\text { Estlmated loads } \\
\text { and yields }\end{array}$} & \multicolumn{3}{|c|}{ Uncertalnty factors, In percent } \\
\hline & & $\mathbf{N}$ & & $\begin{array}{c}\text { Mean } \\
\text { annual } \\
\text { load, } \\
\text { in tons }\end{array}$ & $\begin{array}{c}\text { Mean } \\
\text { annual } \\
\text { yleid, } \\
\text { in tons } \\
\text { per } \\
\text { square } \\
\text { mlle }\end{array}$ & $\begin{array}{l}\text { Standard } \\
\text { error of } \\
\text { regression }\end{array}$ & $\begin{array}{c}\text { Flow } \\
\text { duration } \\
\text { of } \\
\text { greatest } \\
\text { sampled } \\
\text { dlscharge }\end{array}$ & $\begin{array}{l}\text { Proportion } \\
\text { of load } \\
\text { estimate } \\
\text { beyond } \\
\text { range of } \\
\text { sampled } \\
\text { discharge }\end{array}$ \\
\hline
\end{tabular}

$\begin{array}{rlrlrcccc}2.0 & \text { No Fk Ky R nr Jackson } & 38 & 0 & 86,200 & 78.3 & 11.6 & <0.05 & 0 \\ 2.3 & \text { M Fk Ky R at Tallega } & 38 & 0 & 23,200 & 43.2 & 20.9 & .2 & .918 \\ 2.6 & \text { S Fk Ky R at Booneville } & 37 & 0 & 25,600 & 35.5 & 21.2 & .3 & 3.78 \\ 4.0 & \text { Ky R at Lock 10 } & 37 & 0 & 347,000 & 87.7 & 21.9 & <.05 & 0 \\ 8.0 & \text { Ky R at Lock 4 } & 38 & 0 & 601,000 & 111 & 21.5 & <.05 & 0 \\ 9.4 & \text { Elkhorn Ck at Frankfort } & 29 & 0 & 117,000 & 247 & 17.6 & .3 & 6.76 \\ 10.0 & \text { Ky R at Lock 2 } & 39 & 0 & 794,000 & 128 & 23.5 & <.05 & 0 \\ & & & & \text { Alkalinity, dissolved } & & & \\ 2.0 & \text { No Fk Ky R nr Jackson } & 39 & 0 & 70,800 & 64.3 & 11.3 & <0.05 & 0 \\ 2.3 & \text { M Fk Ky R at Tallega } & 39 & 0 & 19,100 & 35.5 & 20.6 & .2 & .920 \\ 2.6 & \text { S Fk Ky R at Booneville } & 38 & 0 & 22,100 & 30.6 & 22.5 & .3 & 4.00 \\ 4.0 & \text { Ky R at Lock 10 } & 40 & 0 & 292,000 & 73.8 & 22.4 & <.05 & 0 \\ 8.0 & \text { Ky R at Lock 4 } & 39 & 0 & 503,000 & 92.9 & 21.5 & <.05 & 0 \\ 9.4 & \text { Elkhorn Ck at Frankfort } & 37 & 0 & 96,800 & 205 & 18.1 & .3 & 0 \\ 10.0 & \text { Ky R at Lock 2 } & 39 & 0 & 646,000 & 105 & 22.7 & <.05 & 0 \\ & & & \text { Sulfate, dissolved, as SO } & & & \\ 2.0 & \text { No Fk Ky R nr Jackson } & 47 & 0 & 161,000 & 145 & 38.8 & <0.05 & 0 \\ 2.3 & \text { M Fk Ky R at Tallega } & 47 & 0 & 34,400 & 64.0 & 21.6 & .2 & 1.17 \\ 2.6 & \text { S Fk Ky R at Booneville } & 46 & 0 & 42,100 & 58.3 & 19.0 & .3 & 3.63 \\ 4.0 & \text { Ky R at Lock 10 } & 48 & 0 & 296,000 & 74.9 & 29.1 & <.05 & 0 \\ 8.0 & \text { Ky R at Lock 4 } & 47 & 0 & 346,000 & 64.0 & 25.1 & <.05 & 0 \\ 9.4 & \text { Elkhorn Ck at Frankfort } & 45 & 0 & 24,800 & 52.4 & 16.1 & .3 & 5.16 \\ 10.0 & \text { Ky R at Lock 2 } & 49 & 0 & 354,000 & 57.3 & 21.7 & <.05 & 0\end{array}$


Table 4. Estimated loads and yields of major ions at the fixed stations in the Kentucky River Basin, April 1987-March 1990-Continued

[N, number of observations; DL, detection limit; <, less than; No, North; Fk, Fork; Ky, Kentucky; R, River, nr, near, M, Middle; S, South; Ck, Creek]

\begin{tabular}{|c|c|c|c|c|c|c|c|c|}
\hline \multirow[b]{2}{*}{$\begin{array}{l}\text { Station } \\
\text { number }\end{array}$} & \multirow[b]{2}{*}{$\begin{array}{c}\text { Station } \\
\text { name }\end{array}$} & & \multirow[b]{2}{*}{$\begin{array}{l}N \\
\text { less } \\
\text { than } \\
D L\end{array}$} & \multicolumn{2}{|c|}{$\begin{array}{l}\text { Estimated loads } \\
\text { and yleids }\end{array}$} & \multicolumn{3}{|c|}{ Uncertainty factors, in percent } \\
\hline & & $\mathbf{N}$ & & $\begin{array}{l}\text { Mean } \\
\text { annual } \\
\text { load, } \\
\text { In tons }\end{array}$ & $\begin{array}{c}\text { Mean } \\
\text { annual } \\
\text { yleld, } \\
\text { in tons } \\
\text { per } \\
\text { square } \\
\text { mlle }\end{array}$ & $\begin{array}{l}\text { Standard } \\
\text { error of } \\
\text { regresslon }\end{array}$ & $\begin{array}{c}\text { Flow } \\
\text { duration } \\
\text { of } \\
\text { greatest } \\
\text { sampled } \\
\text { dlscharge }\end{array}$ & $\begin{array}{l}\text { Proportion } \\
\text { of load } \\
\text { estimate } \\
\text { beyond } \\
\text { range of } \\
\text { sampled } \\
\text { discharge }\end{array}$ \\
\hline
\end{tabular}

\begin{tabular}{|c|c|c|c|c|c|c|c|c|}
\hline 2.0 & No Fk Ky R nr Jackson & 47 & 0 & 6,860 & 6.23 & 24.9 & $<0.05$ & 0 \\
\hline 2.3 & M Fk Ky R at Tallega & 47 & 0 & 2,270 & 4.23 & 26.1 & .2 & .956 \\
\hline 2.6 & S Fk Ky R at Booneville & 46 & 0 & 5,270 & 7.30 & 48.4 & .3 & 1.83 \\
\hline 4.0 & Ky R at Lock 10 & 47 & 0 & 53,800 & 13.6 & 51.7 & $<.05$ & 0 \\
\hline 8.0 & Ky $R$ at Lock 4 & 47 & 0 & 64,300 & 11.9 & 47.0 & $<.05$ & 0 \\
\hline 9.4 & Elkhorn Ck at Frankfort & 45 & 0 & 9,040 & 19.1 & 28.5 & .3 & 3.24 \\
\hline 10.0 & Ky R at Lock 2 & 48 & 0 & 69,300 & 11.2 & 37.8 & $<.05$ & 0 \\
\hline \multicolumn{9}{|c|}{ Fluoride, dissolved, as F1 } \\
\hline 2.0 & No Fk Ky R nr Jackson & 23 & 1 & 167 & 0.152 & 33.9 & $<0.05$ & 0 \\
\hline 2.3 & M Fk Ky R at Tallega & 23 & 3 & 73.5 & .137 & 33.0 & .2 & 1.32 \\
\hline 2.6 & S Fk Ky R at Booneville & 23 & 2 & 103 & .143 & 33.5 & .3 & 4.94 \\
\hline 4.0 & Ky $R$ at Lock 10 & 26 & 1 & 670 & .170 & 33.6 & $<.05$ & 0 \\
\hline 8.0 & Ky $\mathrm{R}$ at Lock 4 & 25 & 1 & 866 & .160 & 30.8 & $<.05$ & 0 \\
\hline 9.4 & Elkhorn Ck at Frankfort & 23 & 1 & 215 & .456 & 47.6 & .3 & 3.33 \\
\hline 10.0 & Ky $\mathrm{R}$ at Lock 2 & 36 & 0 & 1,100 & .179 & 27.2 & $<.05$ & 0 \\
\hline \multicolumn{9}{|c|}{ Bromide, dissolved, as $\mathrm{Br}$} \\
\hline 2.0 & No Fk Ky R nr Jackson & 47 & 11 & 22.0 & 0.020 & 89.4 & $<0.05$ & 0 \\
\hline 2.3 & M Fk Ky R at Tallega & 47 & 17 & 11.0 & .021 & 87.4 & .2 & 1.24 \\
\hline 2.6 & S Fk Ky R at Booneville & 46 & 9 & 21.4 & .030 & 72.3 & .3 & 2.19 \\
\hline 4.0 & Ky $R$ at Lock 10 & 47 & 4 & 241 & .061 & 78.6 & $<.05$ & 0 \\
\hline 8.0 & Ky $\mathrm{R}$ at Lock 4 & 46 & 8 & 257 & .047 & 109 & $<.05$ & 0 \\
\hline 9.4 & Elkhorn Ck at Frankfort & 44 & 8 & 15.2 & .032 & 93.3 & .3 & 4.80 \\
\hline 10.0 & Ky $R$ at Lock 2 & 47 & 7 & 262 & .042 & 96.7 & $<.05$ & 0 \\
\hline
\end{tabular}


Table 4. Estimated loads and yields of major ions at the fixed stations in the Kentucky River Basin, April 1987-March 1990-Continued

[N, number of observations; DL, detection limit; <, less than; No, North; Fk, Fork; Ky, Kentucky; R, River, nr, near, M, Middle; S, South; Ck, Creek]

\begin{tabular}{|c|c|c|c|c|c|c|c|c|}
\hline \multirow[b]{2}{*}{$\begin{array}{l}\text { Statlon } \\
\text { number }\end{array}$} & \multirow[b]{2}{*}{$\begin{array}{l}\text { Station } \\
\text { name }\end{array}$} & \multirow[b]{2}{*}{$\mathbf{N}$} & \multirow[b]{2}{*}{$\begin{array}{c}N \\
\text { less } \\
\text { than } \\
\text { DL }\end{array}$} & \multicolumn{2}{|c|}{$\begin{array}{l}\text { Estlmated loads } \\
\text { and yields }\end{array}$} & \multicolumn{3}{|c|}{ Uncertainty factors, In percent } \\
\hline & & & & $\begin{array}{l}\text { Mean } \\
\text { annual } \\
\text { load, } \\
\text { In tons }\end{array}$ & $\begin{array}{c}\text { Mean } \\
\text { annual } \\
\text { yleld, } \\
\text { In tons } \\
\text { per } \\
\text { square } \\
\text { mile }\end{array}$ & $\begin{array}{l}\text { Standard } \\
\text { orror of } \\
\text { regresslon }\end{array}$ & $\begin{array}{c}\text { Flow } \\
\text { duration } \\
\text { of } \\
\text { greatest } \\
\text { sampled } \\
\text { discharge }\end{array}$ & $\begin{array}{l}\text { Proportion } \\
\text { of load } \\
\text { estimate } \\
\text { beyond } \\
\text { range of } \\
\text { sampled } \\
\text { discharge }\end{array}$ \\
\hline \multicolumn{9}{|c|}{ Silica, dissolved, as $\mathrm{SiO}_{2}$} \\
\hline 2.0 & No Fk Ky R nr Jackson & 47 & 0 & 10,300 & 9.35 & 65.5 & $<0.05$ & 0 \\
\hline 2.3 & M Fk Ky R at Tallega & 47 & 0 & 4,860 & 9.05 & 24.0 & .2 & 1.59 \\
\hline 2.6 & S. Fk Ky R at Booneville & 46 & 1 & 6,900 & 9.55 & 33.7 & .3 & 8.06 \\
\hline 4.0 & Ky R at Lock 10 & 48 & 0 & 37,200 & 9.42 & 22.5 & $<.05$ & 0 \\
\hline 8.0 & Ky $\mathrm{R}$ at Lock 4 & 47 & 0 & 44,300 & 8.18 & 45.2 & $<.05$ & 0 \\
\hline 9.4 & Elkhorn Ck at Frankfort & 44 & 0 & 5,890 & 12.4 & 194 & .3 & 11.5 \\
\hline 10.0 & Ky $R$ at Lock 2 & 49 & 0 & 53,700 & 8.69 & 58.7 & $<.05$ & 0 \\
\hline
\end{tabular}

Dissolved-sulfate concentrations ranged from 18 to $340 \mathrm{mg} / \mathrm{L}$ in the Kentucky River Basin (table 3). The median dissolved-sulfate concentration was $160 \mathrm{mg} / \mathrm{L}$ in the North Fork Kentucky River at Jackson, and the range was from 44 to $59 \mathrm{mg} / \mathrm{L}$ at the other six fixed stations. The high concentrations of sulfate in the North Fork Kentucky River result from coal mining, which exposes sulfides to accelerated weathering and oxidation (Smoot and others, 1991). Mean annual loads of dissolved sulfate (table 4) were highest in the Kentucky River at Lock 2 but mean annual yields were highest in the North Fork Kentucky River (145 ton/ $\mathrm{mi}^{2}$ ), compared to the other fixed stations.

Dissolved-chloride concentrations ranged from 1.4 to $98 \mathrm{mg} / \mathrm{L}$ at the fixed stations in the Kentucky River Basin (table 3). Median concentrations ranged from $4.2 \mathrm{mg} / \mathrm{L}$ in the Middle Fork Kentucky River at Tallega to $23 \mathrm{mg} / \mathrm{L}$ in Elkhorn Creek at Frankfort. Mean annual loads of dissolved chloride (table 4) were lowest in the Middle Fork Kentucky River at Tallega and highest in the Kentucky River at Lock 2, whereas mean annual yields were highest in Elkhorn Creek at Frankfort, compared to the other fixed stations. High dissolved-chloride concentrations are associated with the wastewater discharges from urban areas prevalent in the Elkhom Creek Subbasin (Smoot and others, 1991).

Fluoride and bromide were found at low concentrations in the Kentucky River Basin during 1987-90. Median concentrations of fluoride ranged from 0.10 to $0.40 \mathrm{mg} / \mathrm{L}$, and median concentrations of bromide ranged from 0.01 to $0.05 \mathrm{mg} / \mathrm{L}$ (table 3 ). Mean annual loads of both constituents were highest in the Kentucky River at Lock 2, compared to the other fixed stations (table 4). The high mean annual yield of fluoride in Elkhorn Creek at Frankfort may be attributable to the discharge of fluoridated drinking water and various industrial sources from the urban Lexington area (Smoot and others, 1991). Concentrations of dissolved silica ranged from 0.04 to $24 \mathrm{mg} / \mathrm{L}$ in the Kentucky River Basin. Median concentrations of dissolved silica ranged from 4.8 to $6.0 \mathrm{mg} / \mathrm{L}$ at the fixed stations. Mean annual loads of dissolved silica 
were highest in the Kentucky River at Lock 2, but mean annual yields were highest in Elkhorn Creek at Frankfort, compared to the other fixed stations. There were no statistically significant temporal trends in concentrations of major ions in the Kentucky River Basin for the period of study.

Dissolved-gross-alpha radioactivity ranged from less than 0.04 to $2.4 \mu \mathrm{g} / \mathrm{L}$ at the fixed stations (table 5). Suspended-gross-alpha radioactivity ranged from less than 0.40 to $97 \mu \mathrm{g} / \mathrm{L}$. Median concentrations of both forms were highest in the North Fork Kentucky River at Jackson during 1987--90. Dissolved-gross-beta radioactivity ranged from 1.0 to $13 \mathrm{pCi} / \mathrm{L}$ and suspended-gross-beta radioactivity ranged from less than 0.40 to $63 \mathrm{pCi} / \mathrm{L}$.

\section{Synthetic Organic Compounds Other Than Pesticides}

The production and use of synthetic organic compounds have increased dramatically over the last 50 years and have been accompanied by an increasing incidence of organic contaminants in the Nation's surface water (Smith and others, 1987). Suspended sediment and streambed sediment interact with organic contaminants through various natural processes. Sediment particles commonly transport contaminants and may function as a reservoir for organic compounds in aquatic systems (Witkowski and others, 1987). Although USEPA regulations typically address concentrations of contaminants in water, many studies of contaminants in aquatic systems measure contaminant concentrations in sediment because many persistent organic compounds have low solubility in water but a high affinity for sediment particles.

Detectable concentrations of 19 nonpesticide organic compounds were found in samples of streambed sediment from 13 sites in the Kentucky River Basin in October 1987 (table 6). Polynuclear aromatic hydrocarbons (PAH's) were found in streambed sediment at every site. It is not possible to compare the incidence of PAH's in 1987 to the historical record because only one PAH determination was found in the 1976-86 data base for the Kentucky River Basin (Smoot and others, 1991). Phenol was found in streambed sediment at only one site in 1987 (Town Branch at Viley Road), at a relatively high concentration $(1,297 \mu \mathrm{g} / \mathrm{kg})($ Smith and others, 1987). Phenol was detected in two streambed-sediment samples during 1976-86 in the Kentucky River Basin, at a maximum concentration of $180 \mu \mathrm{g} / \mathrm{kg}$ (Smoot and others, 1991). Phthalates were found in streambed sediment of Town Branch $(9,076 \mu \mathrm{g} / \mathrm{kg})$, Hickman Creek $(340 \mu \mathrm{g} / \mathrm{kg})$, and Quicksand Creek $(259 \mu \mathrm{g} / \mathrm{kg})$ in 1987. Concentrations of these compounds fall within the range of sediment concentrations reported in streambed sediments of other streams ( 5.5 to $56,000 \mu \mathrm{g} / \mathrm{kg}$ ), although reported environmental levels of phthalate esters may be inaccurate because of possible natural origins of these compounds and contamination of samples from the plastic of sample containers (Smith and others, 1987).

Detectable concentrations of 19 nonpesticide organic compounds were found in sediment samples collected at 26 sites in the Kentucky River Basin in November 1988 (table 7). PAH's were widespread in streambed-sediment samples. Phenol was detected in streambed sediment at only one site, the Kentucky River at Lock 10 , and was present at a very high concentration $(8,800 \mu \mathrm{g} / \mathrm{kg})$. Phenols are fairly soluble in water but, with the exception of highly chlorinated phenols, little sorption of phenols to natural sediments occurs (Smith and others, 1987). Because this study did not include parallel analyses of water samples, the understanding of the distribution of phenols in the Kentucky River Basin is incomplete. Phthalate esters were found in streambed sediment at most sites sampled in the Kentucky River Basin in November 1988. Bis(2-ethlyhexyl)phthalate was found at almost every site; concentrations ranged from 380 to $79,000 \mu \mathrm{g} / \mathrm{kg}$. 


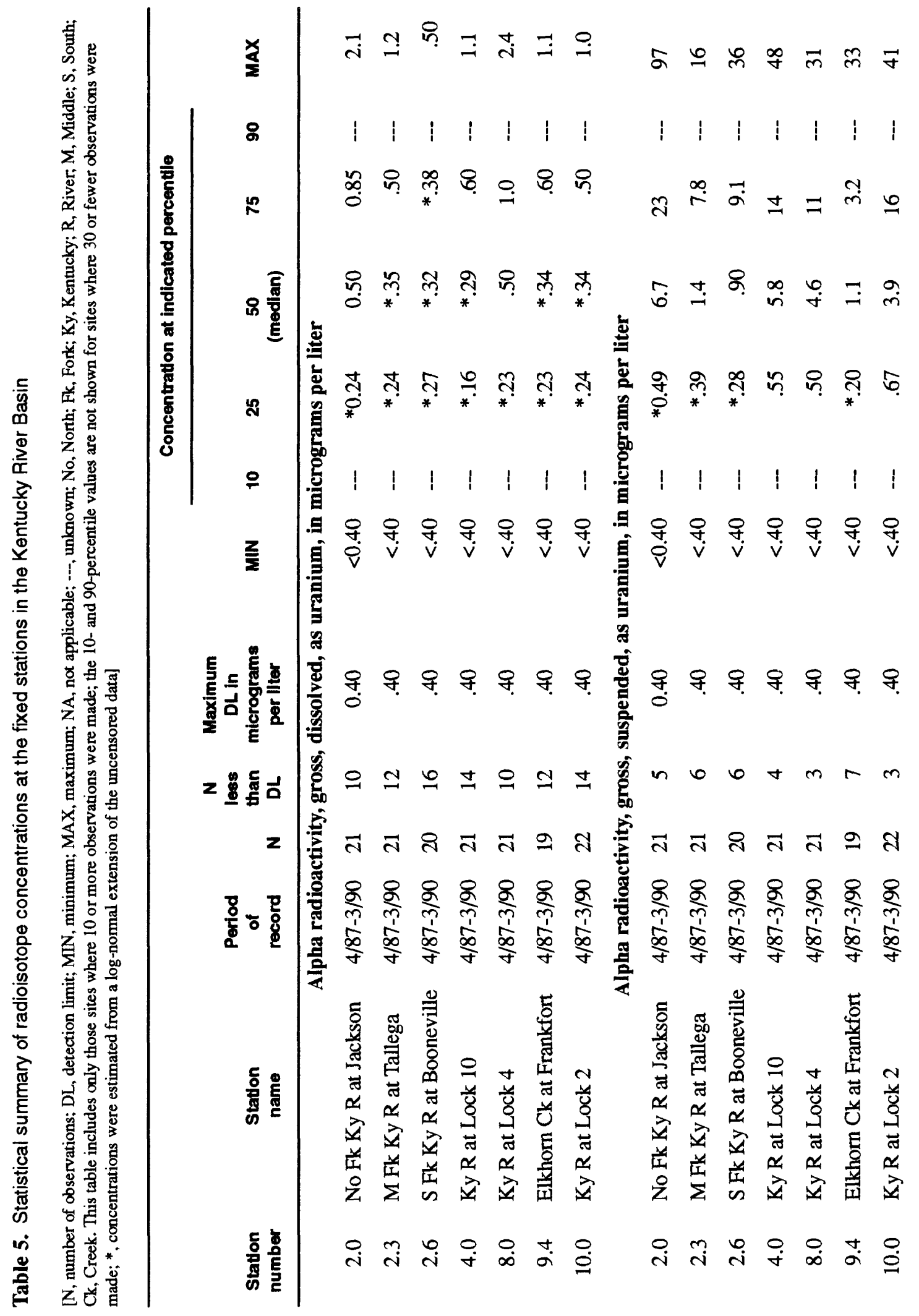




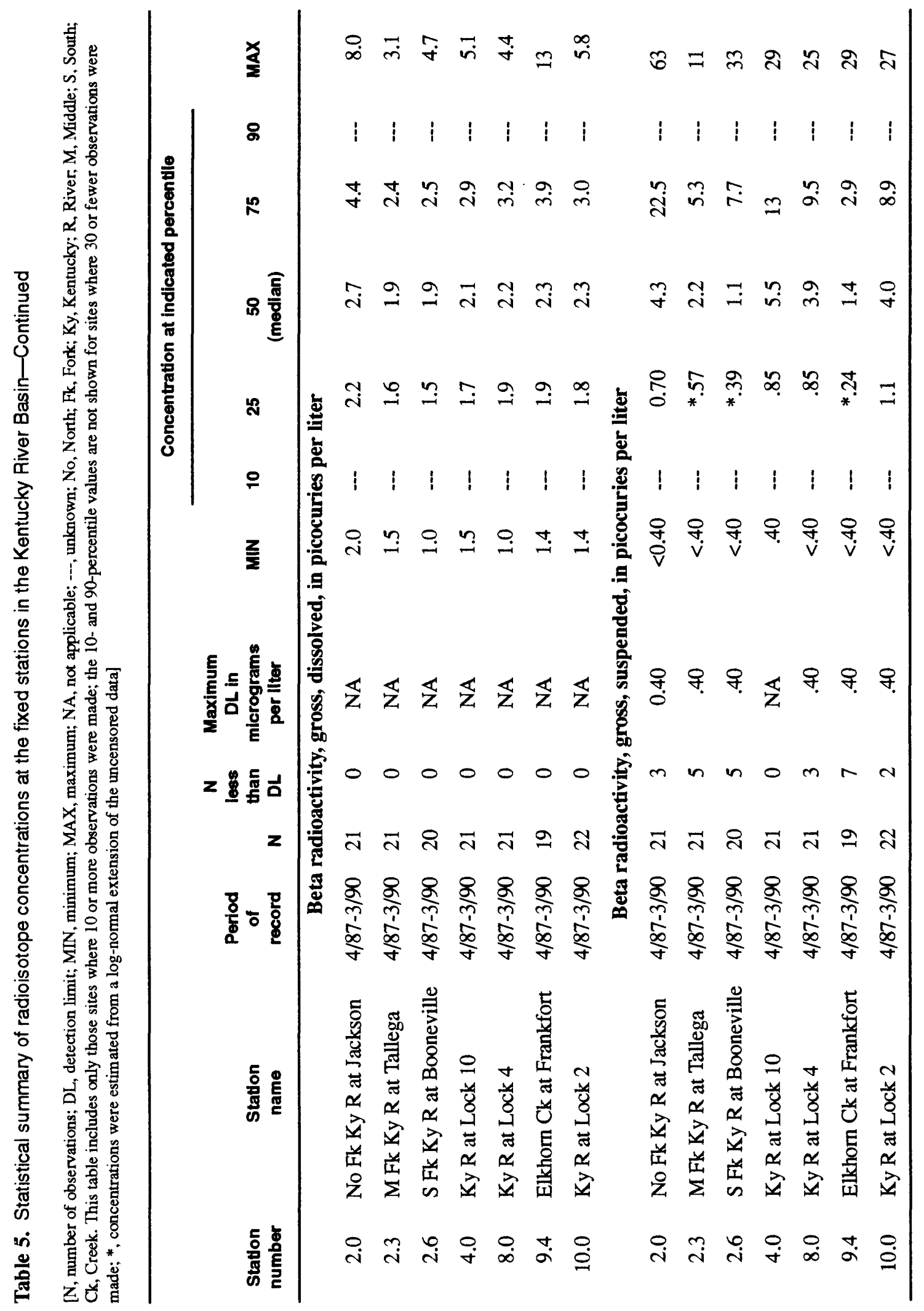

32 Water-Quality Assessment of the Kentucky Rlver Basin, Kentucky:

Results of Investigations of Surface-Water Quality, 1987-90 


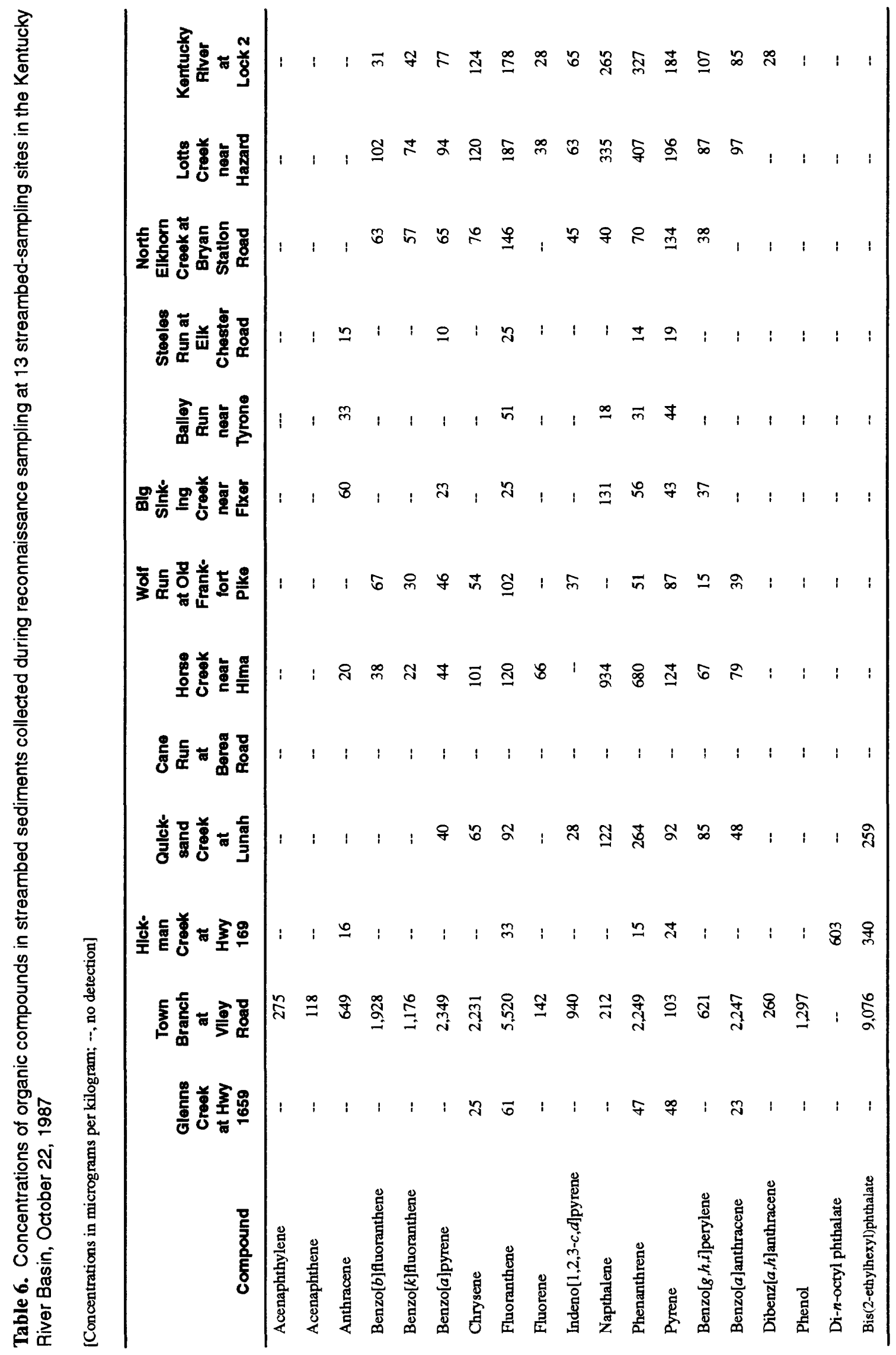




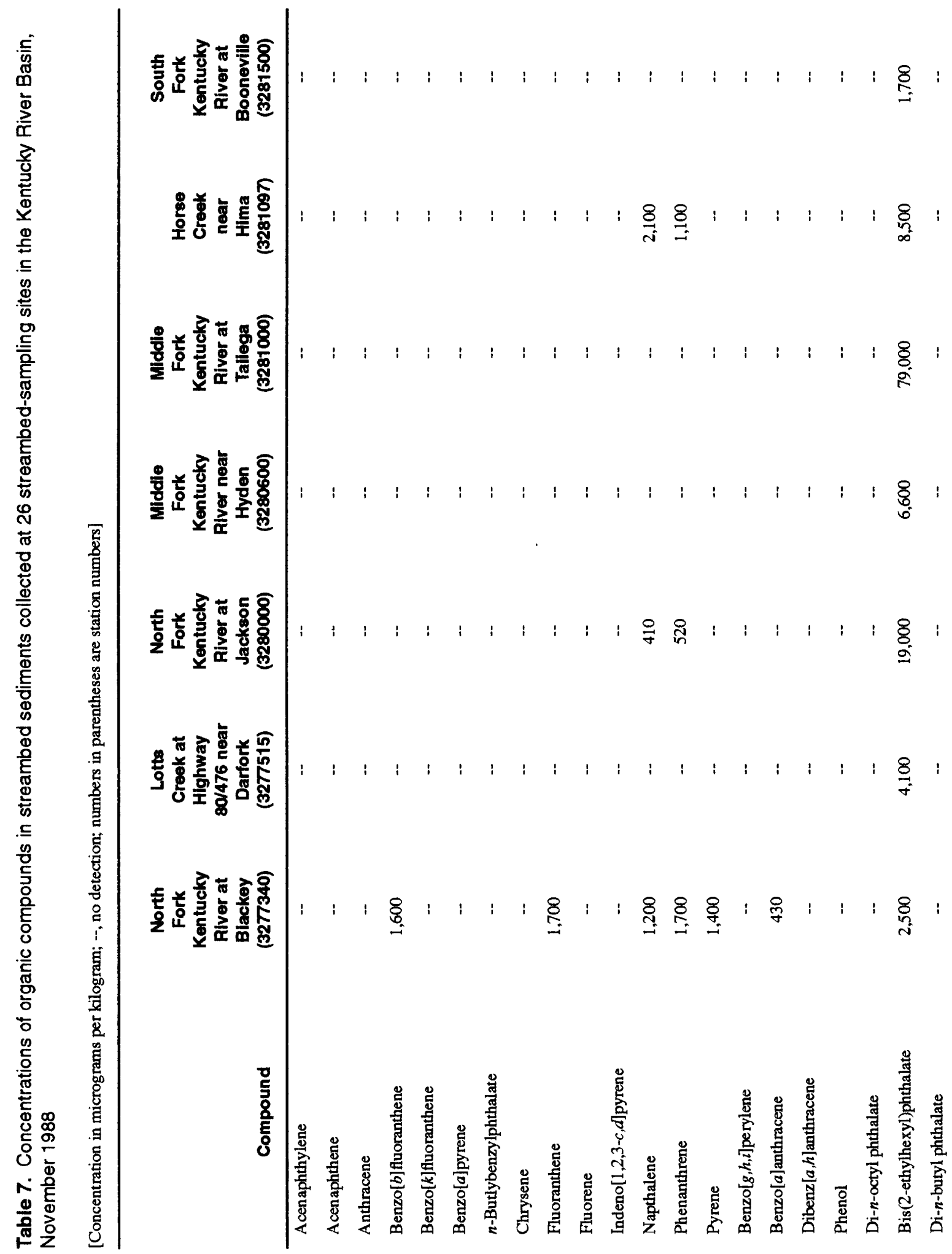




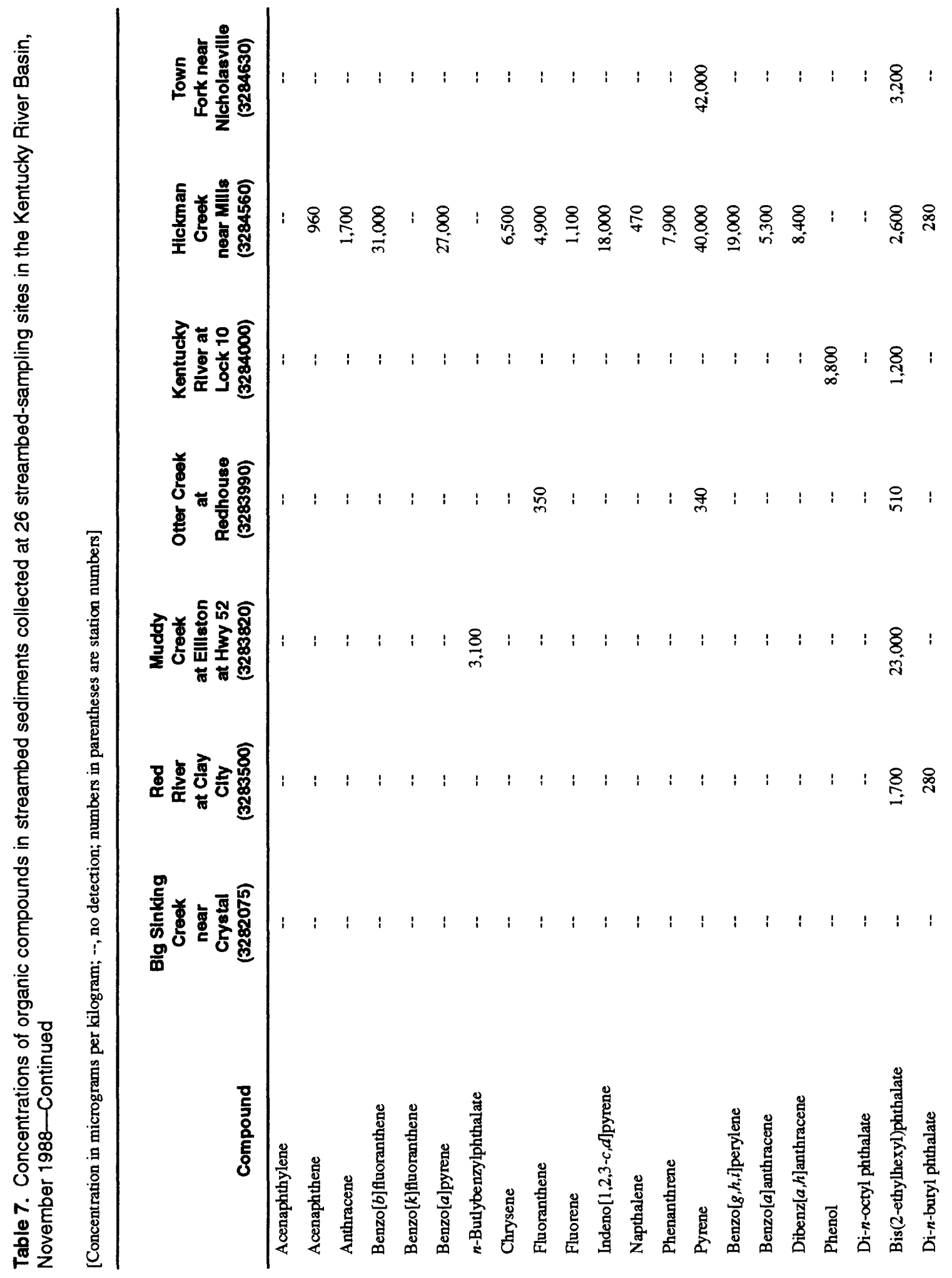




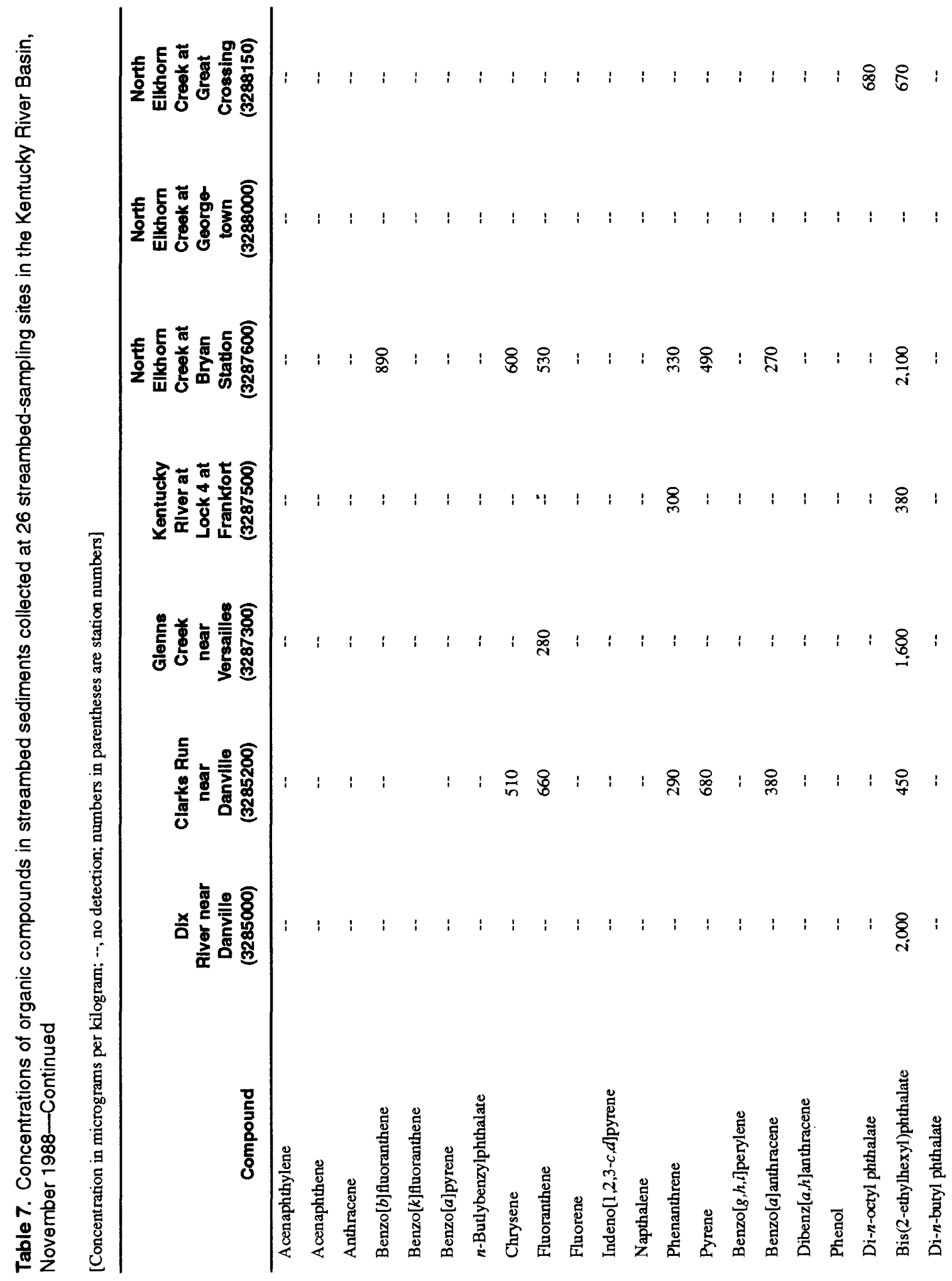




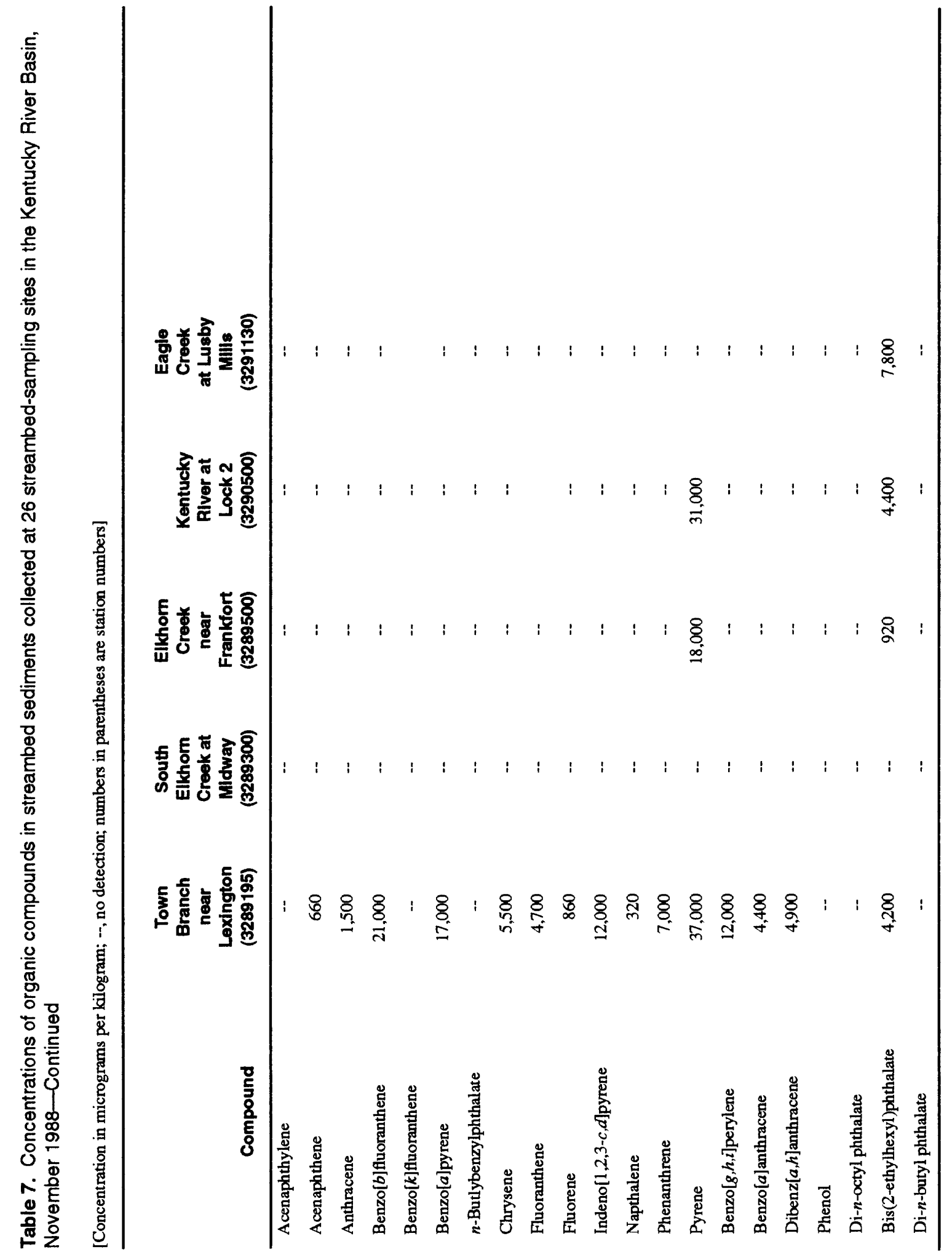




\section{Fecal-Indicator Bacteria}

The sanitary quality of surface waters is an important water-quality issue in many river basins. An assessment of the sanitary quality of surface waters is vital to reducing the risk of waterborne disease and permitting the continued safe use of rivers for domestic, recreational, and aquacultural purposes. The threat of diseases such as typhoid, cholera, and bacillary and amebic dysentery, attributed to infectious organisms transported in waters contaminated by fecal bacteria, has been largely reduced by modern water-treatment practices. However, public health in many areas of the country continues to be at risk from fecal contamination. Of particular concern is the incidence of gastroenteritis (Parmelee, 1990; Craun, 1991), the susceptibility to infection of individuals receiving immunosuppressant therapy (Edberg, 1992), and the proliferation of bacterial strains resistant to antibiotics (Kaspar and others, 1990). The ability to quickly and accurately identify waterbome infectious organisms and the sources of contamination is central to resolving these concerns.

The NAWQA program, along with many other local, regional, and national programs designed to assess the sanitary quality of water, relies on the identification of fecal-indicator bacteria. Although waterhome infectious organisms can be isolated and identified in any well-equipped and staffed lahoratory, isolation of infectious organisms is generally time consuming, complicated, and costly when compared to identification of fecal-indicator bacteria. Fecal-indicator bacteria occur naturally in the intestines of humans and other warm-blooded animals. They are referred to as "indicator organisms" because their presence in water samples indicates that fecal contamination has occurred and that other, more pathogenic infectious organisms are likely to be present. The most widely used tests for fecal contamination in surface waters used for domestic and recreational purposes throughout the United States are designed to identify three major groups of enteric bacteria: total coliform; fecal coliform; and fecal streptococcus. However, these fecal-indicator-bacteria tests are not as specific as they were once believed to he because non-fecal-coliform bacteria identified in these tests can result in false indications of fecal contamination. An alternative test for the presence of fecal contamination has been developed to identify $E$. coli, a member of the fecal-coliform group, which is considered a more specific indicator of fecal contamination that other enteric bacteria (Dufour, 1977). Therefore, $E$. coli was selected by the NAWQA program to assess the sanitary quality of surface water in the Kentucky River Basin. Surface-water samples were also analyzed for fecal coliform and fecal streptococcus to maintain comparability with historical records.

\section{Basin-Scale Distribution of Fecal-Indicator Bacteria}

Water samples were collected by the USGS at three fixed stations $(4.0,9.4,10.0)$ during April 1987March 1990 and counts of fecal-indicator hacteria were determined (table 8). Median counts of fecalcoliform bacteria were similar in the Kentucky River at Lock $10(145 \mathrm{col} / 100 \mathrm{~mL})$ and in the Kentucky River at Lock $2(173 \mathrm{col} / 100 \mathrm{~mL})$. Counts were lower in Elkhorn Creek near Frankfort $(83 \mathrm{col} / 100 \mathrm{~mL})$ than at the main-stem fixed stations.

Data that summarize counts of fecal-coliform hacteria from samples collected at $11 \mathrm{KDOW}$ sites during 1980-90 are included in table 8. The period of record for counts of fecal-coliform bacteria was less than 5 years at two of the KDOW stations (Kentucky River below Frankfort, station 9.0; Kentucky River at Lock 2, station 10.0). KDOW data indicate that median counts of fecal-coliform hacteria in the North Fork of the Kentucky River at Jackson were the highest in the basin $(775 \mathrm{col} / 100 \mathrm{~mL})$. Median counts were much lower in the Middle Fork Kentucky River at Tallega $(86 \mathrm{col} / 100 \mathrm{~mL})$ and South Fork Kentucky River at Booneville $(76 \mathrm{col} / 100 \mathrm{~mL})$. Moderately high median counts of fecal-coliform bacteria $(320 \mathrm{col} / 100 \mathrm{~mL}$ ) were found in the Red River near Hazel Green (site 3.1). Median counts of fecal- 


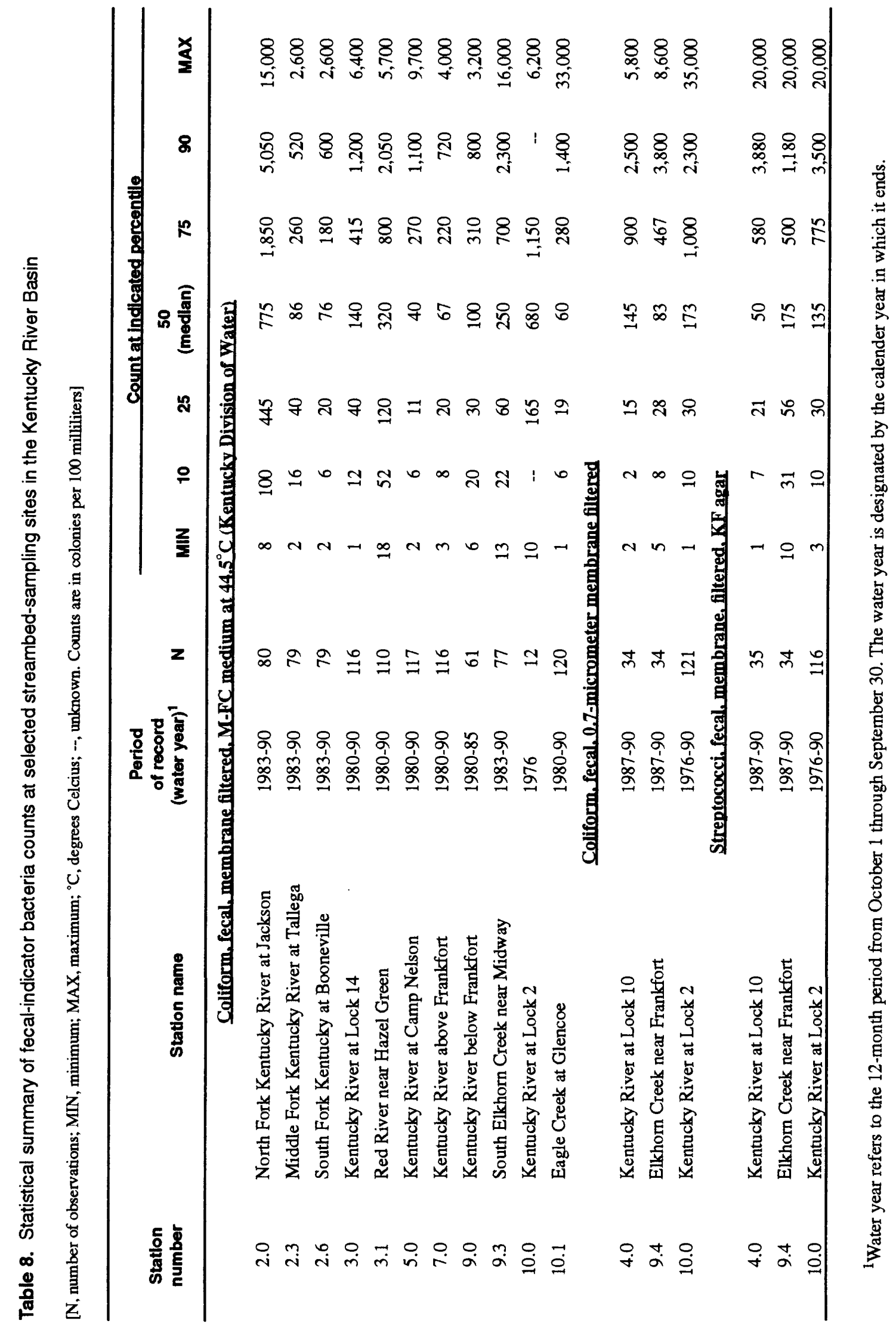


coliform bacteria were moderate in the Kentucky River main stem downstream from the confluence with the Red River. Counts of fecal-indicator bacteria increased in the lower part of the Kentucky River Basin, where the population density is comparatively higher.

The highest counts of fecal-coliform bacteria were recorded in the North Fork Kentucky River at Jackson (station 2.0). The North Fork Kentucky River (fig. 2; table 1) and its tributaries were intensively sampled by the KNREPC during the recreational season of 1992 (May through October) in an effort to resolve swimming advisories that had been issued within the area for the three consecutive years prior to 1992 (Maleva Chamberlain, Kentucky Natural Resources and Environmental Protection Cabinet, written commun., 1994). On the basis of samples collected in May 1992, 22 of 51 small WWTP's (commonly referred to as package plants) and 1 municipal WWTP did not meet discharge-permit requirements for fecal-coliform bacteria. Lower counts of fecal-coliform bacteria were found in samples collected in midSeptember 1992. The KNREPC determined from the results that the high counts of fecal-coliform bacteria in May 1992 originated from sources other than those with discharge permits. Sanitary conditions in the North Fork Kentucky River Subbasin continued to improve, and samples collected during May-June 1993 indicated that major WWTP's in the cities of Fleming-Neon, Whitesburg, Hazard, and Jackson had met their discharge permit requirements for fecal-coliform bacteria (Gary Beck, Kentucky Natural Resources and Environmental Protection Cabinet, written commun., 1994).

\section{Seasonal Distribution of Fecal-Indicator Bacteria}

Counts of fecal-indicator bacteria in the Kentucky River Basin vary with season, and they are influenced by differences in land use and by variations in streamflow. At some sites in the basin, the principal source of contamination is effluent from municipal WWTP's. At these sites (North Fork Kentucky River at Jackson and South Elkhorn Creek near Midway), high counts of fecal-indicator bacteria were found in summer during low flow (fig. 4), when WWTP discharges constitute a large part of total stream discharge. At other sites in the basin, including the Kentucky River above Frankfort and the Kentucky River at Lock 2, the principal sources of fecal contamination are agricultural and urban runoff. At these sites, high counts of fecal-indicator bacteria were found during the winter (January through March), when moderate to high streamflows typically occur. Low counts were observed during the late summer and autumn, when streamflow is also low. Seasonal differences in median fecal-indicator bacteria counts of 1 to 2 orders of magnitude were observed in the Kentucky River at Lock 2. A scatterplot showing fecal-coliform counts as a function of percent flow duration (fig. 5) indicates that fecal-coliform counts in the North Fork Kentucky River at Jackson tended to be high at low flows, whereas high counts of fecalcoliform bacteria in the Kentucky River above Frankfort occurred at high flows.

\section{Exceedences of State Water-Quality Criteria for Fecal-Indicator Bacteria}

The KNREPC has established water-quality criteria for three categories of water use based on the geometric mean of fecal-coliform-bacteria counts. The categories are primary contact in recreational waters, secondary contact in recreational waters, and domestic water use. The criterion for primary contact in recreational waters $(200 \mathrm{col} / 100 \mathrm{~mL})$ is applicable in Kentucky during May 1-October 31 (Kentucky Natural Resources and Environmental Protection Cabinet, 1990b). This criterion was not met in more than 20 percent of the water samples collected during water years 1976-90 (table 9). Swimming advisories were posted during the late 1980's in areas of South Elkhorn Creek and the North Fork Kentucky River Subbasin. Health concerns prompted the closing of the beach on the Kentucky River at Fort Boonesborough State Park in 1990 when fecal-coliform counts exceeded the Kentucky primary contact recreation criterion for the third consecutive year. In 7 to 13 percent of water samples, counts of fecalindicator bacteria exceeded the Kentucky domestic water-supply criterion of 2,000 col/100 mL. In 14 to 15 percent of samples collected at sites throughout the Kentucky River Basin, bacteria counts did not meet 

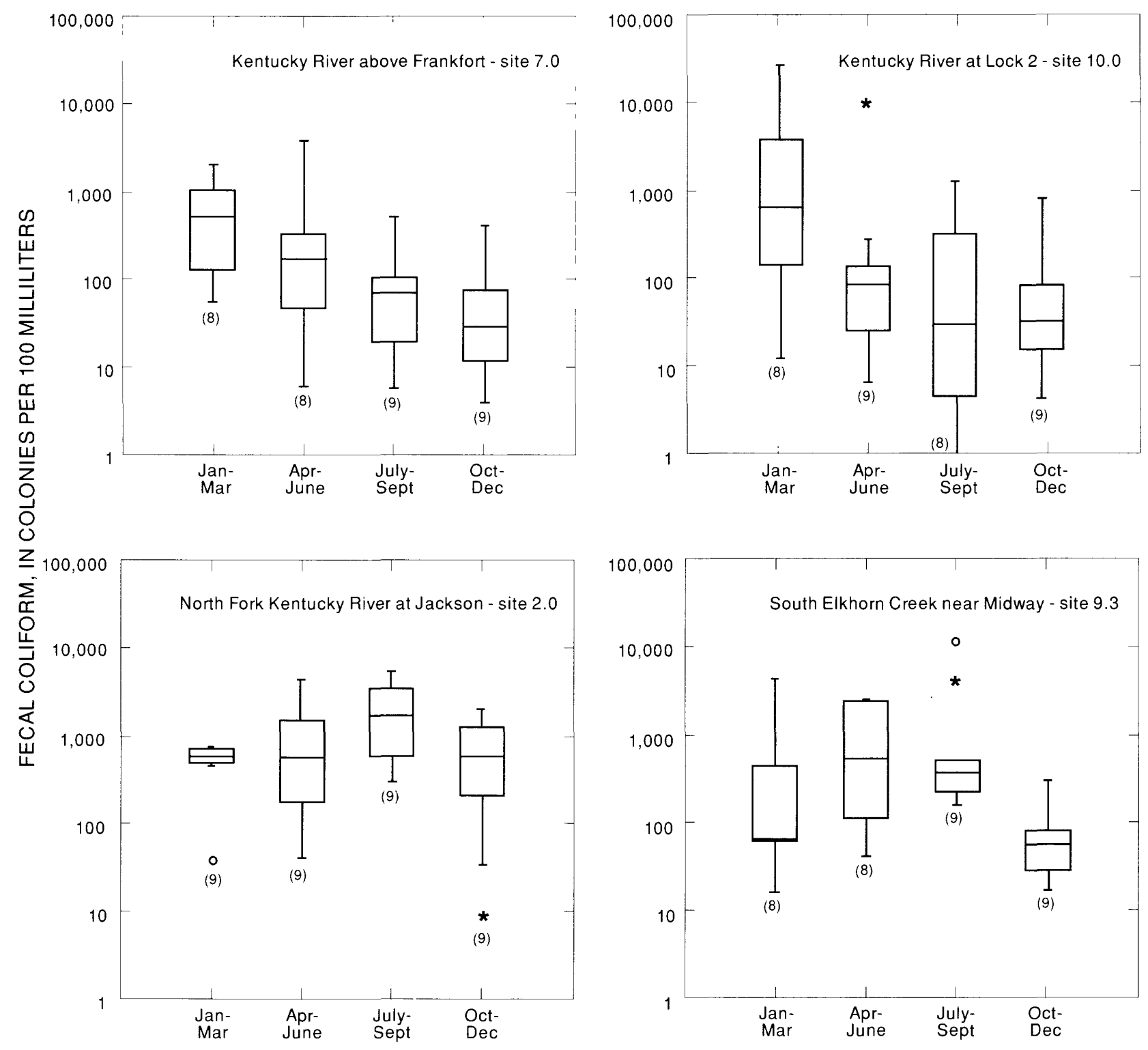

EXPLANATION

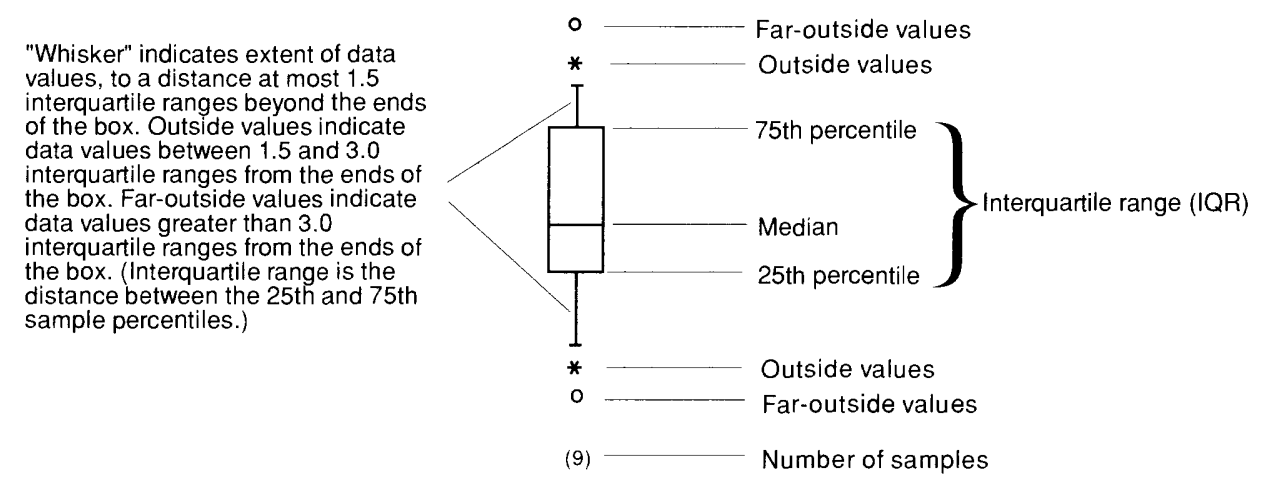

Figure 4. Fecal-coliform counts at selected sites in the Kentucky River Basin, April 1987 - March 1990. 


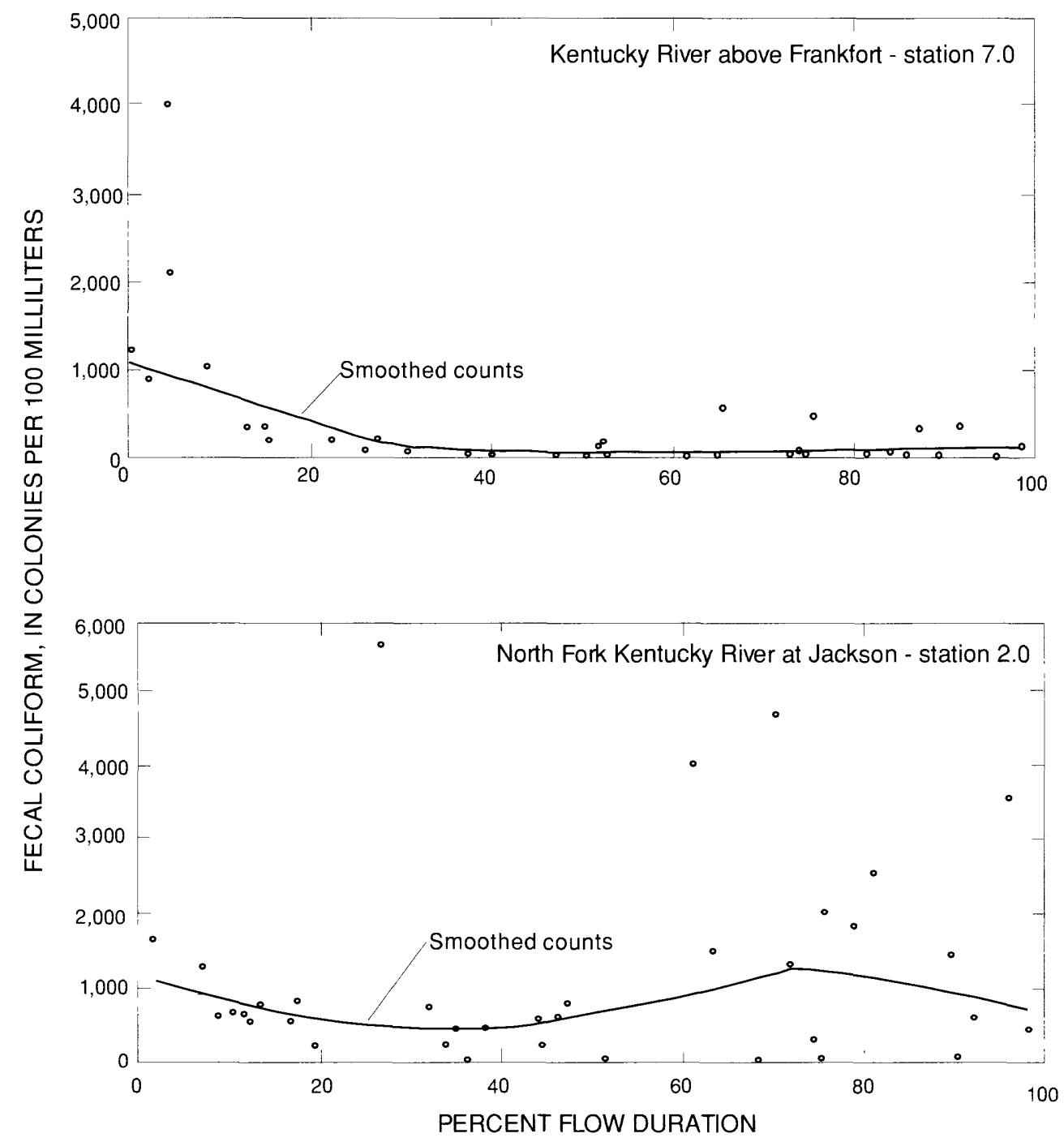

Figure 5. Smoothed fecal-coliform counts and percent flow duration in the North Fork Kentucky River at Jackson and in the Kentucky River above Frankfort, April 1987-

March 1990. (Counts smoothed by use of the Locally Weighted Scatterplot Smoothing technique; Cleveland, 1981.) 
Table 9. Number of fecal-indicator bacteria measurements in the Kentucky River Basin and percentage not meeting indicated water-quality criteria during October 1976-September 1990

[Kentucky criteria ${ }^{1}$ : KYDWS, domestic water supply; KYRP, recreational water-primary contact; KYRS, recreational water-secondary contact. Primary contact period is May 1 through October 31]

\begin{tabular}{|c|c|c|c|c|}
\hline \multirow[b]{2}{*}{$\begin{array}{l}\text { Fecal-Indicator bacterla } \\
\text { measurement }\end{array}$} & \multirow[b]{2}{*}{$\begin{array}{l}\text { Number of } \\
\text { measurements }\end{array}$} & \multicolumn{3}{|c|}{$\begin{array}{l}\text { Percentage of measurements not } \\
\text { meeting Indicated criterla }\end{array}$} \\
\hline & & KYDWS $^{2}$ & KYRP $^{3}$ & KYRS $^{4}$ \\
\hline $\begin{array}{l}\text { Coliform, fecal, membrane } \\
\text { filtered, M-FC medium at } \\
44.5 \text { degrees Celcius }\end{array}$ & 967 & 7 & 20 & 14 \\
\hline $\begin{array}{l}\text { Coliform, fecal, 0.7-micrometer } \\
\text { membrane filtered }\end{array}$ & 189 & 11 & 17 & 15 \\
\hline
\end{tabular}

${ }^{1}$ Kentucky Natural Resources and Environmental Protection Cabinet, $1990 \mathrm{~b}$.

2,000 colonies per 100 milliliters.

${ }^{3} 200$ colonies per 100 milliliters.

${ }^{4} 1,000$ colonies per 100 milliliters.

the recreational water secondary contact criterion of $1,000 \mathrm{col} / 100 \mathrm{~mL}$. A $10-\mathrm{mi}$ reach of the Red River did not meet the full swimming support use category established by the KDOW in 1990 and 1992 (Kentucky Natural Resources and Environmental Protection Cabinet, 1990a, 1992b), despite the fact that most of the Red River Subbasin has been recommended as an Outstanding Resource Water and parts have been given a Kentucky Wild River status (Kentucky Natural Resources and Environmental Protection Cabinet, 1986).

\section{Subbasin-Scale Distribution of Fecal-Indicator Bacteria During Low Flow}

A synoptic survey was done in 1988 to improve the understanding of occurrence and spatial distribution of fecal-indicator bacteria within the Kentucky River Basin. The survey was done in August, during low flow, when point-source contributions predominate and hydrologic conditions tend to be uniform throughout the basin. At 73 stations, including 11 KDOW sites and 3 NAWQA fixed stations, water samples were collected and tested to determine $E$. coli counts. Nearly one-half of these samples were also tested to determine counts of fecal-coliform and fecal-streptococcus bacteria.

E. coli counts ranged from less than 1 to $26,429 \mathrm{col} / 100 \mathrm{~mL}$; the median was $80 \mathrm{col} / 100 \mathrm{~mL}$ (table 10 ). Fecal-coliform counts ranged from less than 1 to $7,300 \mathrm{col} / 100 \mathrm{~mL}$. Almost 16 percent of the 32 samples tested for fecal coliform did not meet the Kentucky criterion of $200 \mathrm{col} / 100 \mathrm{~mL}$ for primary contact in recreational water. Counts of fecal streptococcus ranged from 15 to $2,100 \mathrm{col} / 100 \mathrm{~mL}$.

The full-body-contact bathing criterion for $E$. coli in recreational waters (calculated as the geometric mean of no less than five samples over a 30-day period) is $126 \mathrm{col} / \mathrm{per} 100 \mathrm{~mL}$ (U.S. Environmental Protection Agency, 1986). Although $E$. coli counts in water samples collected in this synoptic survey represent only 1 day and not a 30 -day period, results indicate that $E$. coli contamination may be occurring in some areas. Counts of $E$. coli in samples from nine synoptic survey sites in the Inner Bluegrass Region did not meet the USEPA bathing criteria. The Inner Bluegrass Region is the most densely populated region in the Kentucky River Basin; nearly half the total population of the basin resides within this region in the urban centers of Lexington, Frankfort, Georgetown, Nicholasville, and Versailles. Of the 28 stations where 
Table 10. Statistical summary of fecal-indicator bacteria counts in the Kentucky River Basin collected during the synoptic survey in August 1988

[N, number of observations; MIN, minimum; MAX, maximum; <, less than

Count at Indlcated percentle

\begin{tabular}{|c|c|c|c|c|c|c|c|c|}
\hline $\begin{array}{l}\text { Fecai-Indlcator } \\
\text { bacteria counts }\end{array}$ & $\mathbf{N}$ & MIN & 10 & 25 & $\begin{array}{c}50 \\
\text { (medlan) }\end{array}$ & 75 & 90 & $\operatorname{MAX}$ \\
\hline $\begin{array}{l}\text { Escherichia coli, membrane } \\
\text { filtered, M-TEC medium, } \\
\text { in colonies per } \\
100 \text { milliliters }\end{array}$ & 73 & $<1$ & 3 & 29 & 80 & 420 & 2,100 & 26,429 \\
\hline $\begin{array}{l}\text { Coliform, fecal, } \\
0.7 \text {-micrometer membrane } \\
\text { filtered, in colonies per } \\
100 \text { milliliters }\end{array}$ & 32 & $<1$ & 7 & 14 & 41 & 96 & 410 & 7,300 \\
\hline $\begin{array}{l}\text { Streptococci, fecal, } \\
\text { membrane filtered, } \\
\text { KF agar, in colonies per } \\
100 \text { milliliters }\end{array}$ & 29 & 15 & 21 & 74 & 260 & 760 & 1,400 & 2,100 \\
\hline
\end{tabular}

E. coli counts from single samples not meeting the full-body-contact bathing criterion for recreational waters, nearly one-third were from the North Fork Kentucky River Subbasin (fig. 6). By 1992, several swimming advisories had been posted within this subbasin; and, after intensive sampling efforts by the KDOW, fines were assessed on WWTP's and package plants. Although the situation has improved in the North Fork Kentucky River Basin, high counts of fecal coliform or $E$. coli were reported as a result of the last 1992 survey by KNREPC. It was determined from these results that sources other than those with permits to discharge are the cause of fecal contamination within the basin.

Additional criteria were developed for single samples (U.S. Environmental Protection Agency, 1986) to avoid erroneous closing of any swimming area when "high" $E$. coli counts were recorded in one or only a few of the samples collected for calculating the geometric mean (table 11). One or more of the single samples did not met the indicated criterion in 20 to 32 percent of the samples collected in August 1988. The assumption was that a sample collected during the synoptic survey was representative of sanitary water-quality conditions in the stream reach at least $25 \mathrm{mi}$ upstream of the sampling location. Therefore, results of the synoptic survey in August 1988 indicate that the sanitary quality of approximately 375 to 575 river miles in the Kentucky River Basin was affected by $E$. coli contamination.

\section{Temporal Trends in Concentrations of Fecal-Indicator Bacteria}

Opportunities to discem temporal trends in counts of fecal-indicator bacteria in the Kentucky River Basin were limited by data requirements of Seasonal-Kendall trend tests. The period of record is not sufficient at some sites for such analyses. Results are available, however, for 11 sites where 5 or more years of data were collected. The results of flow-adjusted- and unadjusted-trend analyses for fecalindicator bacteria counts at selected sites in the Kentucky River Basin are given in table 12. Trends with a probability level of less than 0.2 were considered significant. Significant downward trends (flow-adjusted trends or trends unadjusted for flow) indicate a probable reduction in median counts of fecal-indicator bacteria. Downward trends at four stations $(2.0,3.0,9.0,10.0)$ were considered to have greater statistical 


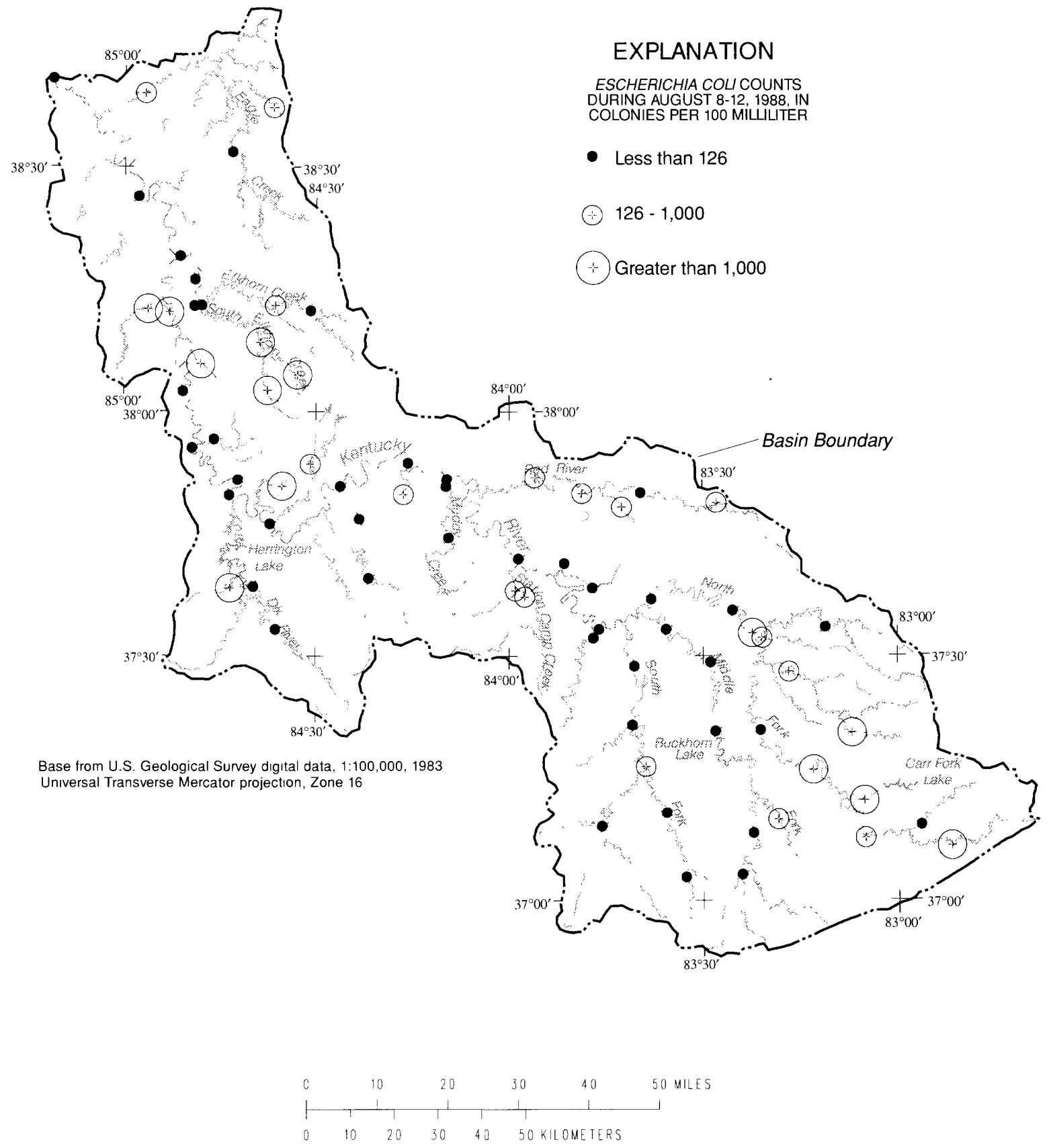

Figure 6. Counts of Escherichia coli bacteria in the Kentucky River Basin during August 8-12, 1988. 
Table 11. Number of Escherichia coli measurements and percentage not meeting indicated water-quality criteria in the Kentucky River Basin during the synoptic survey in August 1988

\begin{tabular}{lccccc}
\hline & \multicolumn{3}{c}{ Percentage of measurements not meeting indicated crlterla' } \\
\cline { 3 - 5 } & $\begin{array}{c}\text { Number of } \\
\text { measurements }\end{array}$ & $\begin{array}{c}\text { Designated } \\
\text { beach area }^{2}\end{array}$ & $\begin{array}{c}\text { Moderate fuil- } \\
\text { contact } \\
\text { recreation }\end{array}$ & $\begin{array}{c}\text { Lightly used } \\
\text { contact } \\
\text { recreation }\end{array}$ & $\begin{array}{c}\text { Infrequent } \\
\text { fuli-body- } \\
\text { contact } \\
\text { recreation }\end{array}$ \\
\hline $\begin{array}{c}\text { Escherichia coli, } \\
\text { membrane filtered, } \\
\begin{array}{l}\text { M-TEC, in colonies per } \\
\text { 100 milliliters }\end{array}\end{array}$ & 73 & 32 & 29 & 27 & 20 \\
\hline
\end{tabular}

${ }^{1}$ Based on single-sample results with one-sided confidence limits (U.S. Environmental Protection Agency, 1986).

2235 colonies per 100 milliliters.

${ }^{3} 298$ colonies per 100 milliliters.

${ }^{4} 406$ colonies per 100 milliliters.

5576 colonies per 100 milliliters.

significance (probability less than 0.05 ) than trends at sites meeting the 0.2 -probability test criterion. The trend slope for these sites represents a reduction in median coliform counts ranging from 14 to 38 percent per year. The upwards trends at two stations $(4.0,9.4)$ may be the result of insufficient seasonal comparisons inherent in the shorter period of record.

Downward trends in the counts of fecal-indicator bacteria in the Kentucky River Basin are likely the results of vigorous efforts to address the issue of bacterial contamination. These efforts include a continued program to educate the population, construct new WWTP's where needed, and maintain a monitoring network to detect changes in the sanitary quality of surface water. Partners in the effort are representatives of the KDOW, the Kentucky Department of Health, the Kentucky River Health Department, the Kentucky River Area Development District, and the Kentucky Division of Plumbing (Maleva Chamberlain, Kentucky Natural Resources and Environmental Protection Cabinet, written commun., 1993). The newly formed Kentucky River Authority also is expected to take part in efforts to improve and maintain the quality of water in the basin.

\section{Dissolved Oxygen}

DO conditions in the Kentucky River and its tributaries were studied during 1987-90 to assess spatial and temporal variability, discern patterns, and verify trends in DO concentrations. Efforts were made to relate DO conditions to land use, water use, and waste-management practices.

\section{Effects of Dissolved Oxygen on Water Quality}

DO is an important indicator of water quality in aquatic systems. Adequate concentrations of DO are vital for the survival of aquatic organisms, for the assimilation of organic and nitrogenous wastes, and for the protection of esthetic qualities of water. Extremely high concentrations of DO are often indicative of nutrient enrichment and excess photosynthetic activity. For the purposes of this study, critical conditions for DO are defined as concentrations less than $5.0 \mathrm{mg} / \mathrm{L}$ and in excess of 105 percent saturation. Potential DO saturation values, which are largely temperature dependent, ranged from $7.3 \mathrm{mg} / \mathrm{L}$ at $32^{\circ} \mathrm{C}$ to $14.6 \mathrm{mg} / \mathrm{L}$ at $0^{\circ} \mathrm{C}$ in the Kentucky River Basin. Species of game fish and forage fish require concentrations 


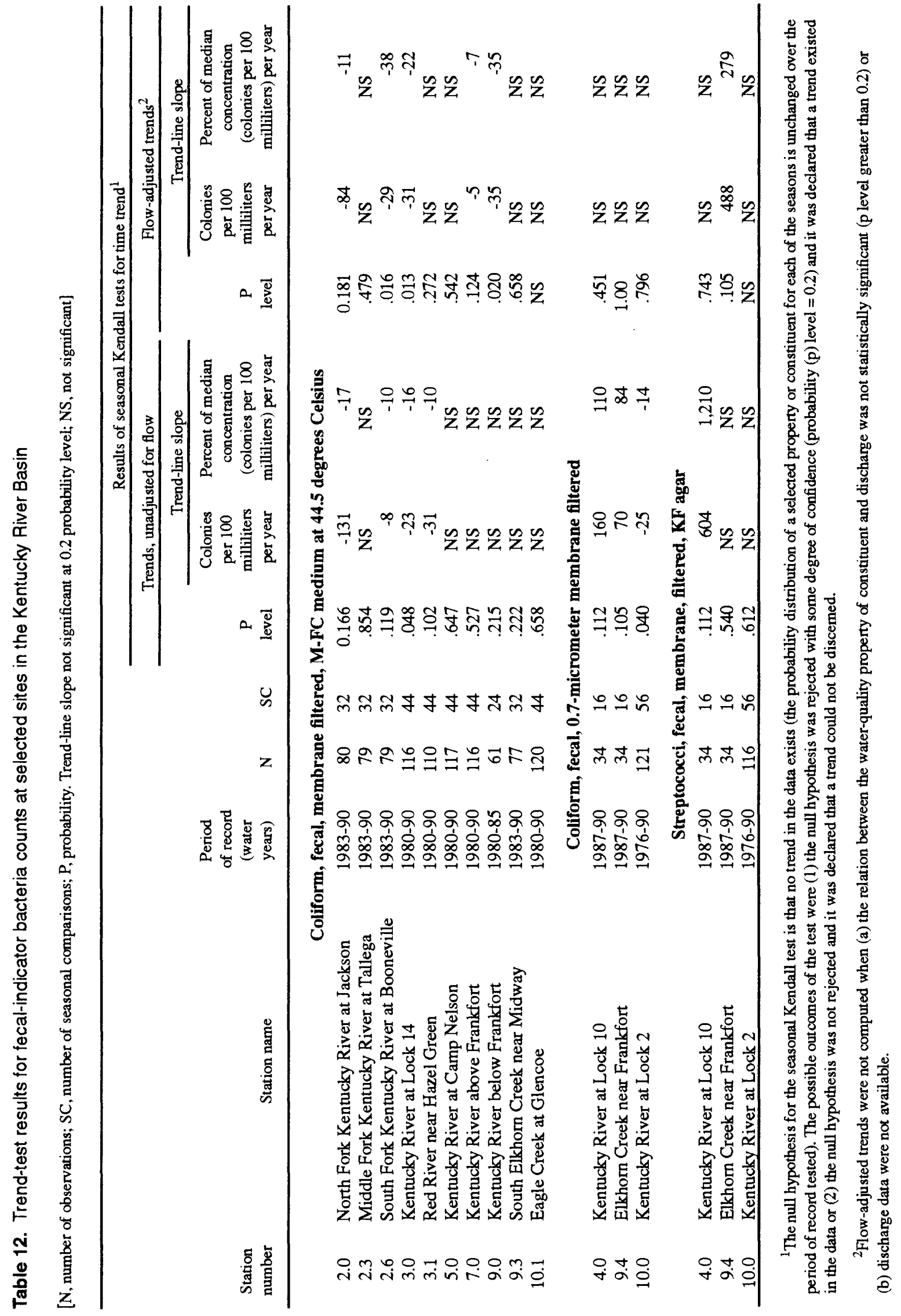


of DO in excess of $5.5 \mathrm{mg} / \mathrm{L}$ for healthy lives and reproductive success (U.S. Environmental Protection Agency, 1985b). Many other aquatic animals such as zooplankton and macroinvertebrates, which provide food for fish, require DO concentrations in excess of $4 \mathrm{mg} / \mathrm{L}$. If DO concentrations drop below $5 \mathrm{mg} / \mathrm{L}$ and remain there for several hours or days, communities of less tolerant organisms may be damaged or destroyed and more tolerant organisms may begin to proliferate. Under these conditions, the water may also lose its esthetic appeal. Esthetic degradation of a water body may be manifest as noxious odors, unsightly biological growths, production of mucilaginous films, and the accumulation of reduced organic compounds and other toxic substances. Metals that have been reduced can be mobilized as a result of increased solubility, resulting in toxicity and impairing the water for many human uses.

Oxygen has a low solubility in water; and because it does not react directly with water, its solubility is directly proportional to the partial pressure of atmospheric oxygen. Temperature affects DO concentrations not only through its effects on solubility, but also because biochemical reaction rates are temperature dependent. Biochemical reactions associated with photosynthesis will increase DO concentrations; reactions associated with the breakdown of organic compounds may reduce DO concentrations.

DO concentrations in streams are affected by the physical characteristics of the stream, water temperature, and biochemical processes. A general mass balance equation for DO that summarizes the potential sources and sinks of DO unique to a specific volume of water in an aquatic system is modified from Thomann and Mueller (1987, p. 266) and presented below:

$$
\begin{aligned}
\mathrm{Vdc} / \mathrm{dt}= & \text { reaeration }+(\text { photosynthesis }- \text { respiration }) \\
& \text { - oxidation of CBOD and NBOD } \\
& \text { - sediment oxygen demand } \\
& + \text { oxygen inputs } \\
& \pm \text { oxygen transport (into or out of volume), }
\end{aligned}
$$

where $\mathrm{V}$ is volume, $\mathrm{dc} / \mathrm{dt}$ is the concentration gradient, $\mathrm{CBOD}$ is carbonaceous biochemical oxygen demand, and NBOD is nitrogenous biochemical oxygen demand.

The equation summarizes the potential sources and sinks of DO unique to a specific volume of water in an aquatic system.

There are three major sources of DO in aquatic systems: hydromechanical reaeration, photosynthesis, and contributions from inflows. Nutrients are often introduced in waste discharges; they may stimulate photosynthetic rates below wastewater discharges so much that DO concentrations reach or exceed saturation. DO sinks may include sediment oxygen demand (SOD), carbonaceous biochemical oxygen demand (CBOD), nitrogenous biochemical oxygen demand (NBOD), and oxidation of reduced inorganic compounds (sulfites, sulfides, and so forth). Oxygen-demanding compounds are abundant in untreated or partially treated sewage and (or) livestock waste, detrital matter from the watershed, and oxidizable minerals and metals.

In addition to seasonal variations, DO concentrations vary over a daily (24-hour) period. Diel or daily variations in DO concentration are controlled by temperature and biological activity. Temperature effects result in changes in DO solubility. As DO solubility increases (for example, in the cool evening hours), the transfer of oxygen from the atmosphere to the water may increase. As the water warms during the day, solubility decreases and the trend reverses. Thus, DO concentrations may increase slightly in the evenings and decrease slightly during the day as a direct result of changes in temperature. 
Variations in biological activity, particularly photosynthesis and cellular respiration, also contribute to diel changes in aquatic DO concentrations. Photosynthesis is a set of biochemical reactions in plant cells that convert light energy to chemical energy. During the light-dependent phase of photosynthesis, oxygen is produced. In the absence of light, photosynthesis does not occur. Cellular respiration takes place during daylight and darkness alike and results in the consumption of oxygen by plants in the water. Thus, it is the net production of oxygen (gross oxygen production minus gross oxygen consumption) that is important. When oxygen production exceeds consumption and diffusion to the atmosphere, DO concentrations may exceed saturation. At saturation, the net transfer of oxygen between the water surface and the atmosphere equals zero. In situations where oxygen is produced in the water faster than it can be transferred to the atmosphere, oxygen accumulates in the water at supersaturated concentrations. To summarize, net oxygen production during the day may result in waters supersaturated with DO. As light intensity decreases in the late aftemoon, so do photosynthetic rates and oxygen production. DO concentrations may then decrease as a function of diffusion to the atmosphere, cellular respiration, and any other oxygen-consuming process. As the evening progresses, oxygen-consuming processes may become predominant, reducing DO concentrations to a minimum in the early moming hours. This daily cycle, commonly referred to as the diel oxygen cycle, may result in subcritical and supercritical DO concentrations within a 24-hour period.

\section{Exceedences of State Water-Quality Standards for Dissolved Oxygen}

Federal and State legislatures have authorized the use of standards to regulate the concentration of DO in many freshwaters. Kentucky water-quality standards are contingent on the legally designated use of a water body. Most streams in the Kentucky River Basin are designated for use as Warmwater Aquatic Habitats (WAH), Primary Contact Recreation (PCR), Secondary Contact Recreation (SCR), and Domestic Water Supply (DWS). Part of the Red River drainage has been designated as an Outstanding Resource Water (ORW) and Coldwater Aquatic Habitat (CAH). Two DO standards apply to the maintenance of a WAH. The "chronic standard" requires that DO concentrations, averaged over a 24-hour period, not be less than $5.0 \mathrm{mg} / \mathrm{L}$. The "acute standard" requires that DO concentrations exceed $4.0 \mathrm{mg} / \mathrm{L}$ at all times (Kentucky Natural Resources and Environmental Protection Cabinet, 1992b).

Of the 479 water samples collected for DO analyses at the fixed stations and the synoptic sites, 11 percent (54) had DO concentrations of less than $5 \mathrm{mg} / \mathrm{L}$, and 5 percent (25) had DO concentrations of less than $4 \mathrm{mg} / \mathrm{L}$. All water samples with DO concentrations of less than $5 \mathrm{mg} / \mathrm{L}$ were collected between June 20 and August 29 in the years sampled. Seventy-eight percent of water samples with DO concentrations less than $5 \mathrm{mg} / \mathrm{L}$ were collected during 0400 to 1000 hours. (About 59 percent of all DO samples collected in the study were collected during this time period.) This time interval coincided with low flows, high temperatures, and the diel DO sag that usually occurs between late evening and early moming.

Smoot and others (1991) reviewed historical DO data collected during 1976-86 in the Kentucky River Basin. Of the $426 \mathrm{DO}$ concentrations measured during this period, approximately 12 percent were below $5.5 \mathrm{mg} / \mathrm{L}$, the Federal criterion for protection of a mature warmwater fishery (U.S. Environmental Protection Agency, 1985b) and 8 percent were less than $4.0 \mathrm{mg} / \mathrm{L}$. Although the time of day when these samples were collected cannot be determined, a comparison with data collected during 1987-90 indicates that DO conditions in the Kentucky River Basin may have improved.

\section{Dissolved-Oxygen Modeling in the Kentucky River Basin}

DO concentrations in the Kentucky River Basin varied spatially and temporally throughout the study. Efforts were made to increase the understanding of water quality in the Kentucky River Basin by modeling the interactions that affect DO in the river system. In order to reduce error in regression models, it is useful 
to group the data so that within-group variability is low and between-group variability is high. To model DO in the Kentucky River Basin, subsets of the DO data were created to reflect differences in the predominant land-use types in the basin. The subsets were then evaluated to generate hypotheses about spatial and temporal variability and the factors that contribute to that variability. Finally, regression models were fitted to subsets of the synoptic and fixed-station data and the concentrations of DO predicted by the models were compared to concentrations measured during the study.

\section{Spatial Variability of Dissolved-Oxygen Concentrations}

The spatial distribution of DO concentrations at synoptic sites during August 1987 and 1988 indicates that most of the critical values occurred in the middle and lower part of the Kentucky River Basin, principally in the Knobs and the Inner and Outer Bluegrass Regions (figs. 7-9). All samples with greater than 105 percent DO saturation were collected from main-stem stations downstream from the mouth of the Dix River at Lock and Dam 7 (Kentucky river mile [RM] 120) (fig. 10). Haag and Porter (1995) report that, for the same time period, highest chlorophyll $a$ concentrations were downstream from Lock and Dam 6 (RM 96). Primary production by phytoplankton/tychoplankton communities developed in the slower moving, nutrient-rich waters in the downstream part of the river may explain the high DO concentrations found in this part of the Kentucky River main stem (fig. 10).

Of the 54 water samples with a DO concentration of less than $5 \mathrm{mg} / \mathrm{L}, 33$ (61 percent) were collected from tributaries to the main stem of the Kentucky River downstream from Lock and Dam 14 (table 13).

Table 13. Dissolved-oxygen concentrations in streams tributary to the Kentucky River downstream from Lock 14, 1987-90

[N, number of samples; mg/L, milligrams per liter]

\begin{tabular}{|c|c|c|c|c|c|c|}
\hline $\begin{array}{c}\text { Dralnage } \\
\text { basin }\end{array}$ & $\mathbf{N}$ & $\begin{array}{l}\text { Minimum } \\
\text { dissolved- } \\
\text { oxygen } \\
\text { concentration } \\
\text { (mg/L) }\end{array}$ & $\begin{array}{l}\text { Maximum } \\
\text { dlssoived- } \\
\text { oxygen } \\
\text { concentration } \\
\text { (mg/L) }\end{array}$ & $\begin{array}{l}\text { Median } \\
\text { dissolved- } \\
\text { oxygen } \\
\text { concentration } \\
\text { (mg/L) }\end{array}$ & $\begin{array}{l}\text { Number } \\
\text { of samples } \\
\text { with } \\
\text { dissolved- } \\
\text { oxygen } \\
\text { concentration } \\
\text { less than } \\
5 \mathrm{mg} / \mathrm{L}\end{array}$ & $\begin{array}{l}\text { Number } \\
\text { of samples } \\
\text { with } \\
\text { dissolved- } \\
\text { oxygen } \\
\text { concentration } \\
\text { less than } \\
4 \mathrm{mg} / \mathrm{L}\end{array}$ \\
\hline Station Camp Creek & 4 & 1.1 & 5.8 & 3.1 & 3 & 2 \\
\hline Red River & 10 & 4.5 & 6.9 & 6.0 & 1 & 0 \\
\hline Muddy Creek & 4 & 3.4 & 6.8 & 4.0 & 3 & 2 \\
\hline Dix River & 6 & 2.9 & 9.6 & 5.5 & 3 & 2 \\
\hline North Elkhorn Creek & 8 & 3.4 & 6.6 & 5.3 & 2 & 1 \\
\hline South Elkhorn Creek & 8 & 1.6 & 7.2 & 4.7 & 6 & 2 \\
\hline Eagle Creek & 7 & 1.5 & 5.7 & 4.4 & 4 & 2 \\
\hline
\end{tabular}




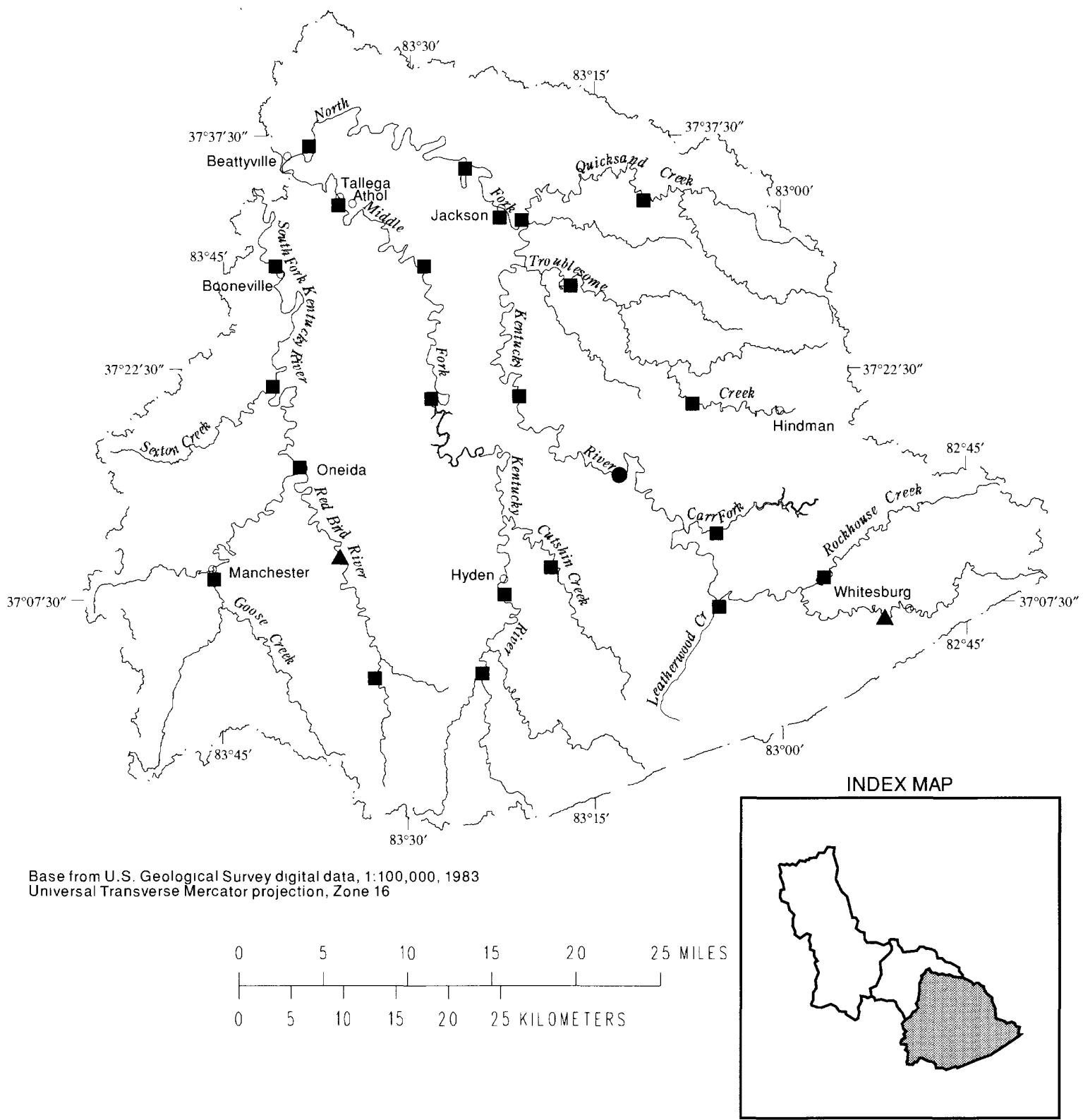

KENTUCKY RIVER BASIN

\section{EXPLANATION}

- In all samples, dissolved-oxygen concentration greater than 5.5 milligrams per liter

A In at least one sample, dissolved-oxygen concentration greater than 4.5 milligrams per liter but less than 5.5 milligrams per liter

- In at least one sample, dissolved-oxygen concentration less than 4.5 milligrams per liter

Figure 7. Concentration of dissolved oxygen in the North, Middle, and South Forks Kentucky River and associated tributaries, 1987-90. 


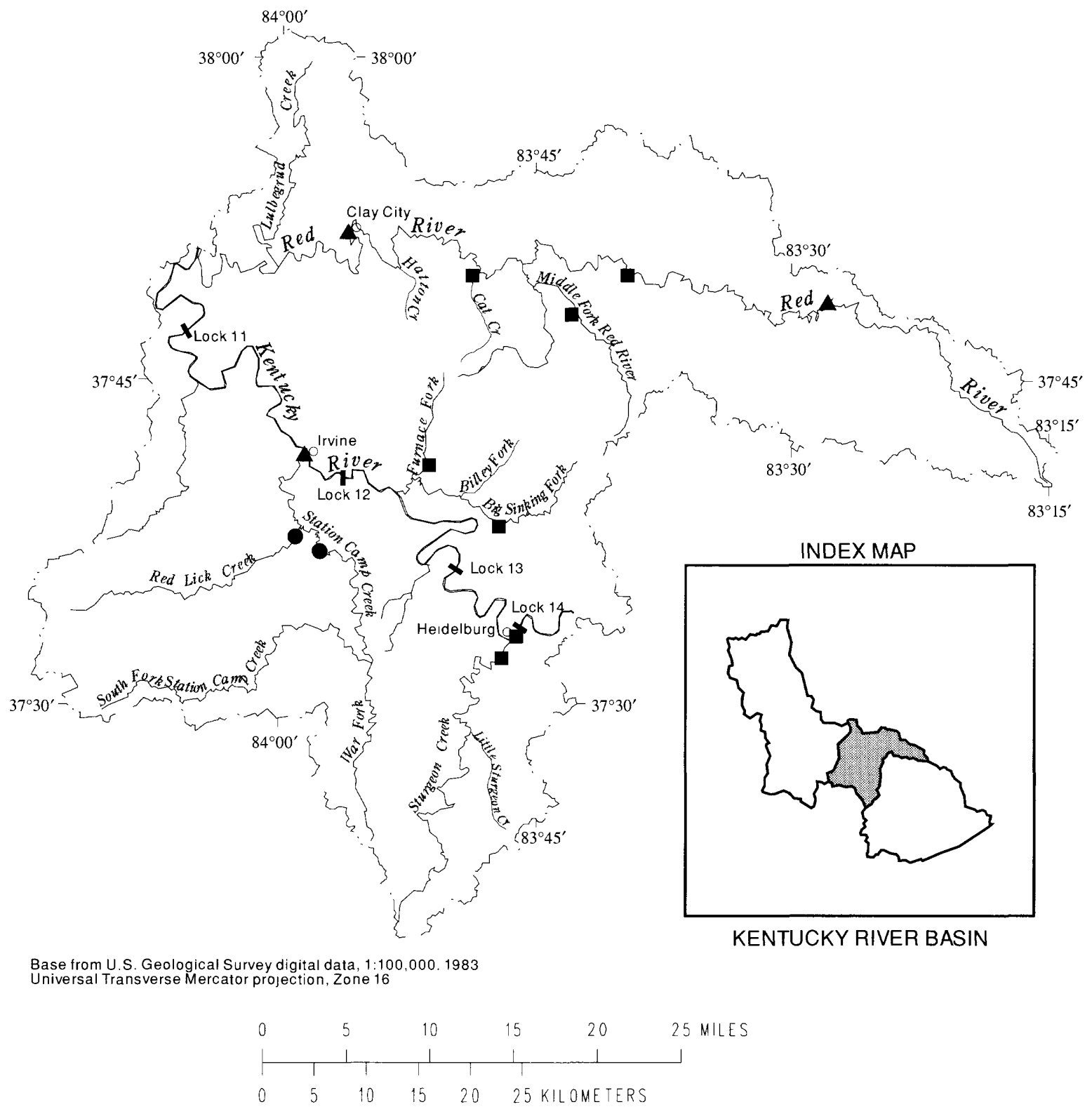

\section{EXPLANATION}

- In all samples, dissolved-oxygen concentration greater than 5.5 milligrams per liter

- In at least one sample, dissolved-oxygen concentration greater than 4.5 milligrams per liter but less than 5.5 milligrams per liter

- In at least one sample dissolved-oxygen concentration less than 4.5 milligrams per liter

Figure 8. Concentration of dissolved oxygen in the Kentucky River and its tributaries from Lock 14 to the confluence with the Red River, 1987-90. 


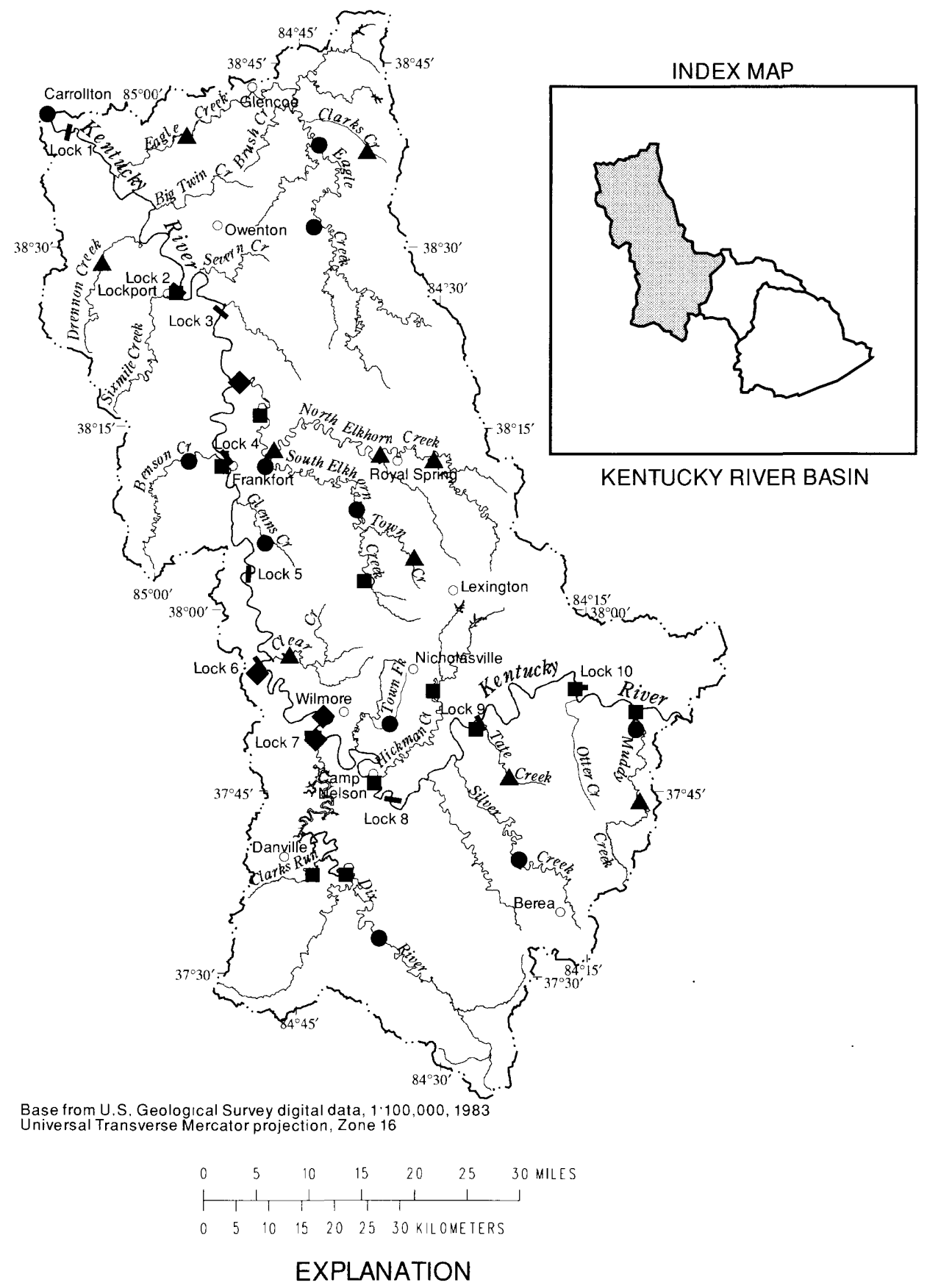

- In at least one sample, dissolved-oxygen concentration greater than 105-percent saturation

- In all samples, dissolved-oxygen concentration greater than 5.5 milligrams per liter but less than 105-percent saturation

A In at least one sample, dissolved-oxygen concentration greater than 4.5 milligrams per liter but less than 5.5 milligrams per liter

- In at least one sample, dissolved-oxygen concentration less than 4.5 milligrams per liter

Figure 9. Concentration of dissolved oxygen in the Kentucky River and its tributaries from the confluence with the Red River to the confluence with the Ohio River, 1987-90. 


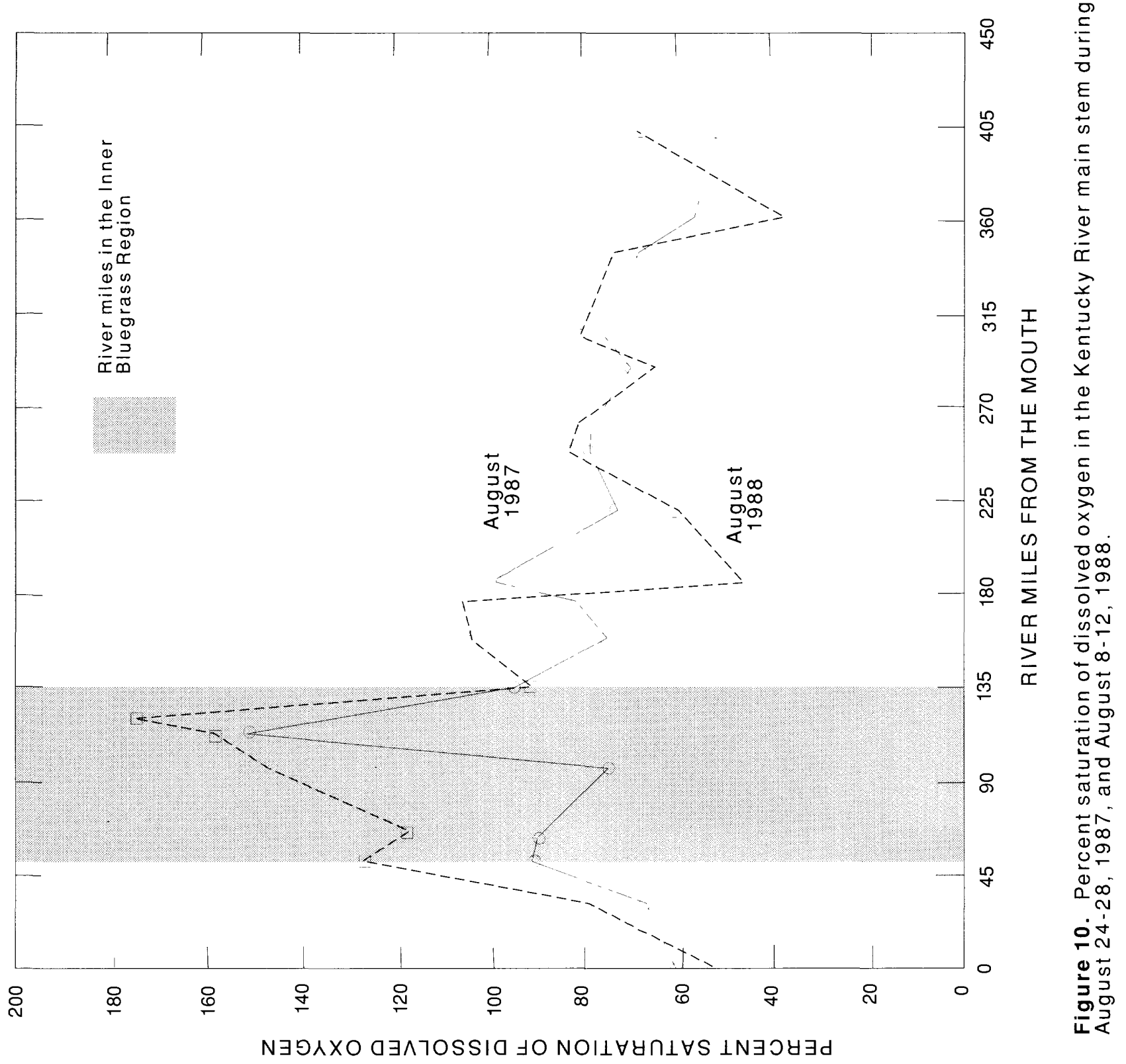


Of the 54 water samples with a DO concentration of less than $5 \mathrm{mg} / \mathrm{L}, 16$ ( 30 percent) were collected from the main stem of the river, 3 were collected from the North Fork of the Kentucky River, and the remaining 4 samples were from the South Fork of the Kentucky River. None of the samples collected from the Middle Fork of the Kentucky River had a DO concentration of less than $5 \mathrm{mg} / \mathrm{L}$. All water samples collected from the tributaries to the North, Middle, and South Forks had DO concentrations greater than $5 \mathrm{mg} / \mathrm{L}$.

The synoptic study revealed that at least one water sample from 13 of the 16 tributaries to the Kentucky River below Lock and Dam 14 (81 percent) had a critically low DO concentration. On four tributaries, each with two or more sampling sites, median DO concentration was less than $5 \mathrm{mg} / \mathrm{L}$. These tributaries have the potential for systematic DO problems. DO concentrations of less than $5 \mathrm{mg} / \mathrm{L}$ were found in all the major tributaries below Lock and Dam 14 (fig. 11). The Red River system appears to be least affected; but even in that drainage, 1 of the 10 samples (10 percent) had a DO concentration of less than $5 \mathrm{mg} / \mathrm{L}$.

DO concentrations measured at the fixed stations generally ranged from 7 to $11 \mathrm{mg} / \mathrm{L}$. Less than 2 percent of the samples had a DO concentration of less than $5 \mathrm{mg} / \mathrm{L}$, and only one sample had a DO concentration of less than $4 \mathrm{mg} / \mathrm{L}$. The fixed-station samples were usually collected between midmoming and late aftemoon; therefore, samples would not be expected to represent the daily minimum DO concentration. Fewer than 7 percent (22) of water samples collected at the fixed stations had a DO concentration that exceeded 105-percent saturation. The highest supersaturations were found in Elkhom Creek near Frankfort. About 86 percent of the samples with supersaturated DO concentrations were collected at the following three sites: the Kentucky River at Lock and Dam 10, the Kentucky River at Lock and Dam 4, and Elkhom Creek at Frankfort.

The distribution of samples containing critical DO concentrations was not uniform with respect to physiographic region in the Kentucky River Basin (table 14). Water samples collected at sites in the Outer Bluegrass had the highest frequency of low DO concentrations, followed by the Knobs Region. Low DO concentrations were measured in the Eastem Coal Field and the Inner Bluegrass, but their frequency of occurrence was lower than it was in the other two physiographic regions. Streams in the Inner Bluegrass apparently support significant algal growth, as indicated by the large number of water samples with DO concentrations greater than 105 -percent saturation.

Table 14. Critical dissolved-oxygen concentrations in streams throughout the four physiographic regions of the Kentucky River Basin, 1987-90

[N, number of samples; $\mathrm{mg} / \mathrm{L}$, milligrams per liter]

\begin{tabular}{lcccc}
\hline Physlographic region' & $\mathbf{N}$ & $\begin{array}{c}\text { Percentage of } \\
\text { samples with } \\
\text { dissolved-oxygen } \\
\text { concentratlon less } \\
\text { than } 5 \mathrm{mg} / \mathrm{L}\end{array}$ & $\begin{array}{c}\text { Percentage of } \\
\text { samples with } \\
\text { dissolved-oxygen } \\
\text { concentratlon less } \\
\text { than } 4 \mathrm{mg} / \mathrm{L}\end{array}$ & $\begin{array}{c}\text { Percentage of } \\
\text { samples with } \\
\text { dissolved-oxygen } \\
\text { saturation greater } \\
\text { than 105 percent }\end{array}$ \\
\hline Inner Bluegrass & 144 & 11 & 6 & 20 \\
Outer Bluegrass & 35 & 37 & 17 & 9 \\
Knobs & 20 & 30 & 15 & 0 \\
Eastern Coal field & 63 & 11 & 2 & 0 \\
\hline
\end{tabular}

${ }^{1}$ Modified from U.S. Department of Agriculture, 1981. 


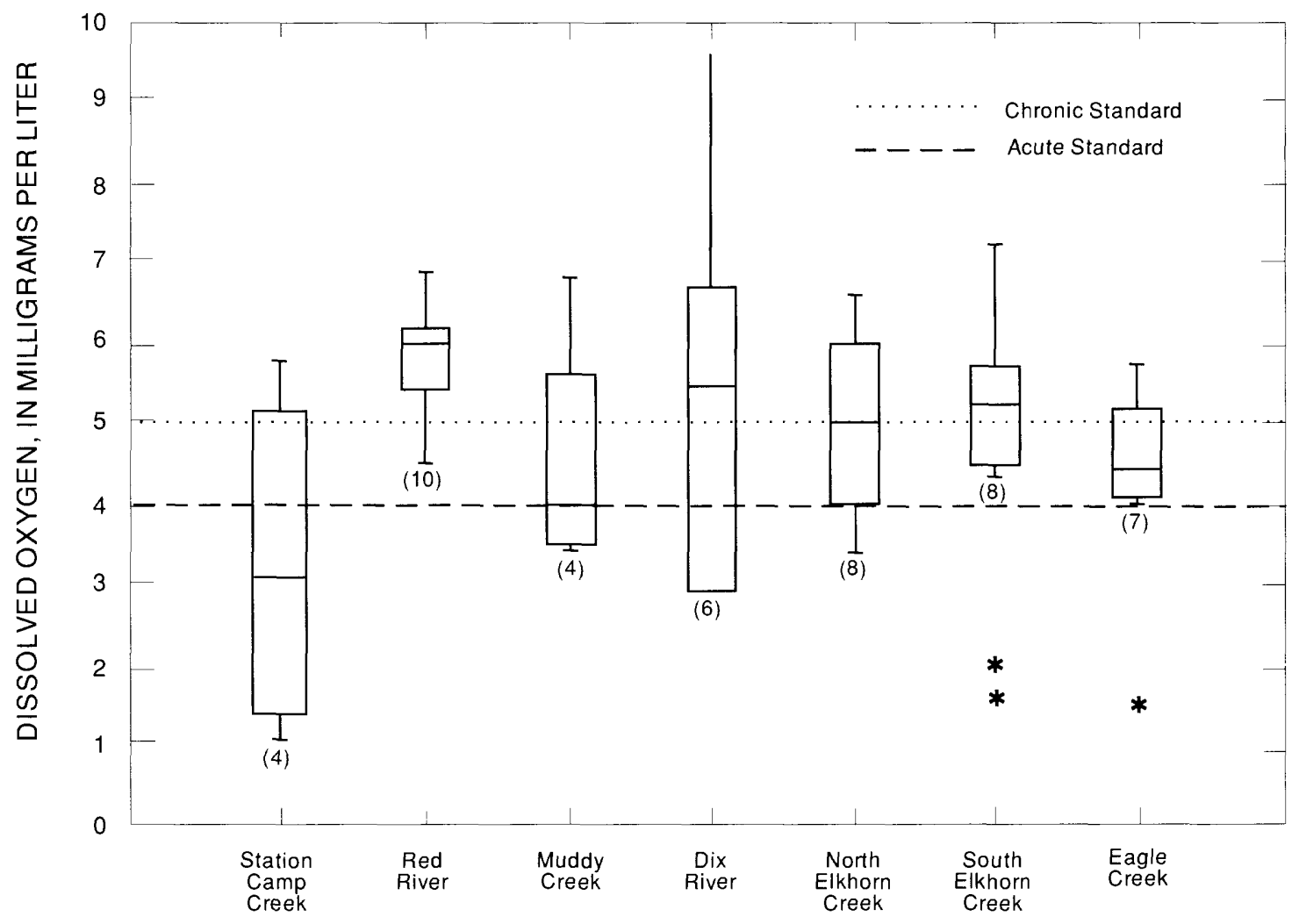

TRIBUTARIES TO THE KENTUCKY RIVER BELOW THE NORTH FORK

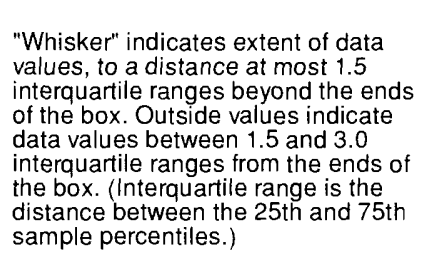

\section{EXPLANATION}

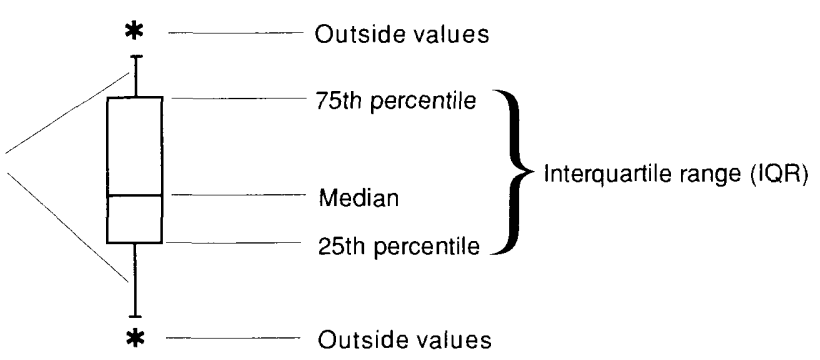

(4) —_ Number of samples

Figure 11. Dissolved-oxygen concentrations measured in major tributary streams in the Kentucky River Basin during August 24-28, 1987, and August 8-12, 1988. 
Most of the low DO concentrations occurred in small drainage basins. More than half the DO concentrations of less than $5 \mathrm{mg} / \mathrm{L}$ were collected in drainages of less than $175 \mathrm{mi}^{2}$, and more than 80 percent were from drainages of less than $724 \mathrm{mi}^{2}$ (table 15). The greatest effect of photosynthetic activity appears to occur in stream reaches with large drainages. These stream reaches, typically on the main stem of the river, are less turbulent and have longer residence times than the smaller streams, are nutrient rich, and do not have overhanging tree canopies that may restrict light.

Table 15. Critical dissolved-oxygen concentrations in drainage basins of different sizes in the Kentucky River Basin, 1987-90

[N, number of samples; $\mathrm{mg} / \mathrm{L}$, milligrams per liter; <, less than ]

\begin{tabular}{ccccc}
\hline $\begin{array}{c}\text { Dralnage- } \\
\text { basin area' } \\
\text { (square mlles) }\end{array}$ & $\mathrm{N}$ & $\begin{array}{c}\text { Percentage of } \\
\text { samples with } \\
\text { dissolved-oxygen } \\
\text { concentration less } \\
\text { than } 5 \text { mg/L }\end{array}$ & $\begin{array}{c}\text { Percentage of } \\
\text { samples with } \\
\text { dlssolved-oxygen } \\
\text { concentration less } \\
\text { than } 4 \mathrm{mg} / \mathrm{L}\end{array}$ & $\begin{array}{c}\text { Percentage of } \\
\text { samples with } \\
\text { dlssolved-oxygen } \\
\text { saturation greater } \\
\text { than 105 percent }\end{array}$ \\
\hline $6-473$ & 110 & 27 & 14 & $<1$ \\
$474-723$ & 19 & 26 & 5 & 0 \\
$724-3,955$ & 16 & 6 & 0 & 13 \\
$3,956-6,956$ & 117 & 5 & 3 & 25 \\
\hline
\end{tabular}

${ }^{1}$ Drainage basins grouped in quartiles.

\section{Cluster Analysis of Land-Use Data}

K-means cluster analysis is a nonhierarchical grouping procedure. It was used to group the data on DO concentrations collected at the fixed stations and at the synoptic sites. The clustering was done by first estimating the percentage of land use in each subbasin where sampling sites were located. The percentage of area covered by four broad land-use types was estimated: mining, forest, agriculture, and urban. The clustering process is iterative. It begins by assigning to an initial group (a partition) all the data points in the immediate neighborhood on the basis of euclidean distance metric (Hartigan, 1975). The process continues by reassigning data points from one partition to another until the error variance within the clusters is minimized relative to the variance between the clusters (Hair and others, 1987). This iterative process results in an analysis of variance for each of the four land-use types with regard to clusters. The $F$-statistics that are generated can be used to assess the utility of each land-use type as a discriminator for the clusters (Hartigan, 1975).

The DO data were initially clustered into three subsets. One of the subsets was extremely small and contained only two DO data points, both for the same sampling site (Town Fork Creek at Nicholasville) (table 2; fig. 2). This cluster was distinctly different from the other clusters because more than 90 percent of the land use in the subbasin was urban. Consequently, the data in this cluster were not used in subsequent analyses. The two remaining clusters were assessed by use of boxplots of clusters as a function of the four land-use percentages (fig. 12). The clusters were significantly different from one another in all four land-use categories. Forest and agricultural land uses were especially good discriminators between clusters, as demonstrated by summary statistics of the land-use percentages within each of the two landuse clusters (table 16). For this reason, the two clusters are subsequently referred to as agriculture and forest. Moreover, there is a relation between land-use clusters and physiographic region in the Kentucky River Basin (table 17). Forest land use is common throughout the Kentucky River Basin and, 

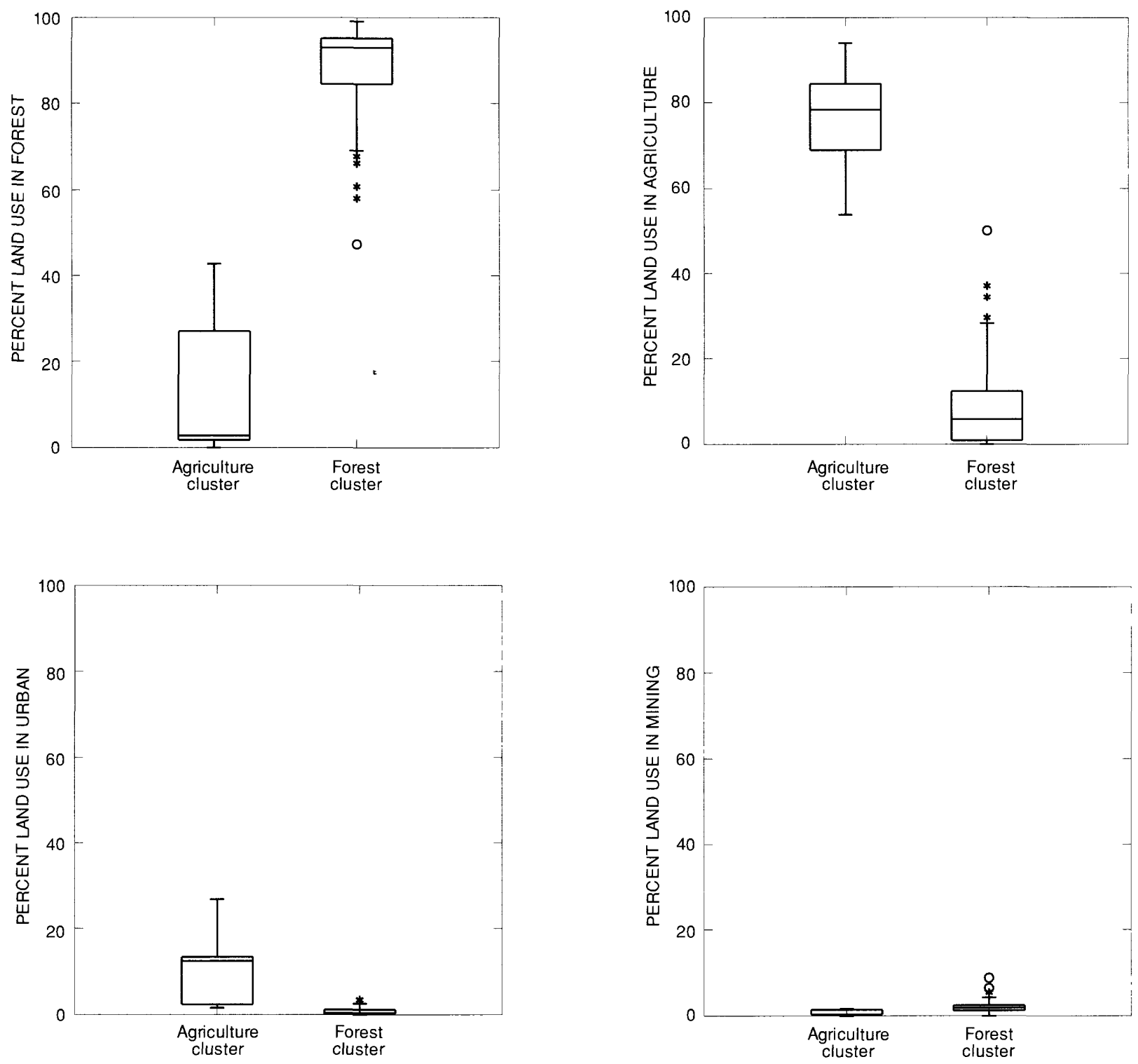

\section{EXPLANATION}

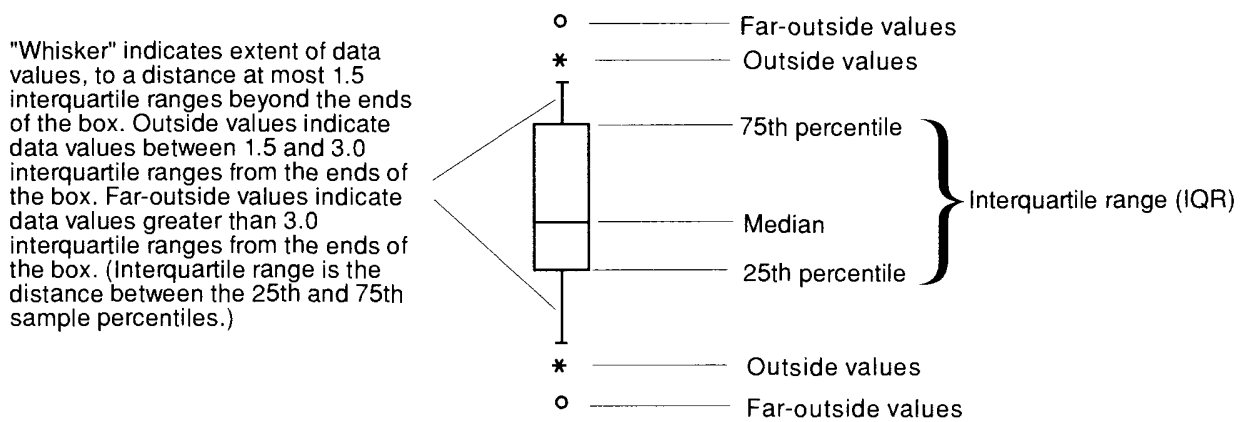

Figure 12. Land-use distribution in each of the land-use clusters in the Kentucky River Basin. 
consequently, the forest cluster includes drainage basins in each physiographic region. Agriculture is widespread throughout the Kentucky River Basin; however, it is present with sufficient frequency in subbasins to warrant their inclusion in the agriculture cluster only in the Inner and Outer Bluegrass and Knobs Regions.

Table 16. Characterization of land use in each of the two land-use clusters used for development of a dissolvedoxygen model for the Kentucky River Basin

\begin{tabular}{|c|c|c|c|c|c|c|c|c|}
\hline \multirow[b]{2}{*}{$\begin{array}{l}\text { Land-use } \\
\text { type }\end{array}$} & \multicolumn{4}{|c|}{ Percentage of land use in forest } & \multicolumn{4}{|c|}{ Percentage of land use in agriculture } \\
\hline & $\begin{array}{l}\text { MInimum } \\
\text { percent- } \\
\text { age }\end{array}$ & Mean & $\begin{array}{l}\text { Maximum } \\
\text { percent- } \\
\text { age }\end{array}$ & $\begin{array}{l}\text { Standard } \\
\text { deviation }\end{array}$ & $\begin{array}{c}\text { Minimum } \\
\text { percent- } \\
\text { age }\end{array}$ & Mean & $\begin{array}{l}\text { Maximum } \\
\text { percent- } \\
\text { age }\end{array}$ & $\begin{array}{l}\text { Standard } \\
\text { devlation }\end{array}$ \\
\hline Forest & 47.3 & 78.1 & 99.1 & 13.0 & 0 & 5.15 & 27.2 & 9.53 \\
\hline Agriculture & 0 & 18.3 & 50.1 & 12.4 & 53.8 & 81.2 & 94.0 & 7.79 \\
\hline Urban & 0 & 1.59 & 3.50 & 1.07 & 1.60 & 13.1 & 26.8 & 4.73 \\
\hline Mining & 0 & 1.84 & 8.80 & 1.02 & 0 & .41 & 1.70 & .27 \\
\hline
\end{tabular}

Table 17. Distribution of water samples collected for dissolved-oxygen analyses in each physiographic region in the forested and agricultural land-use clusters in the Kentucky River Basin

$[\mathrm{N}$, number of samples]

\begin{tabular}{cccc}
\hline & \multicolumn{2}{c}{$\begin{array}{c}\text { Number of } \\
\text { dlssolved-oxygen } \\
\text { samples }\end{array}$} \\
\cline { 3 - 4 } Physlographic reglon & N & $\begin{array}{c}\text { Agricultural } \\
\text { cluster }\end{array}$ & $\begin{array}{c}\text { Forest } \\
\text { cluster }\end{array}$ \\
\hline Inner Bluegrass & 173 & 67 & 106 \\
Outer Bluegrass & 83 & 23 & 60 \\
Knobs & 24 & 3 & 21 \\
Eastern Coal field & 199 & 0 & 199 \\
\hline
\end{tabular}

${ }^{1}$ Modified from U.S. Department of Agriculture, 1981.

\section{Development of the Regression Model}

Regression modeling can have several goals. One goal is to predict the dependent variable from a set of independent variables. A second goal is to quantify the relation between one or more independent variables and the dependent variable. The first approach focuses on finding a model that fits the observed data and predicts future data accurately. The second approach attempts to produce accurate estimates of one or more regression coefficients. This second approach is useful in identifying determinants (predictor variables) of the dependent variable if information on many independent variables is available. 
The relation between many environmental factors and DO concentration is generally nonlinear; this is especially true of the temperature-DO relation. To aid in the interpretation of model results in this study, the investigators decided to fit the DO data from the Kentucky River Basin with linear least-squares equations (Bevington and Robinson, 1992; Kleinbaum and others, 1988). Instantaneous streamflow also was linearized for inclusion in the model by calculating the natural logarithm of each value of instantaneous streamflow. The temperature variable was not linearized. All model statistics, however, are linear.

Multiple-regression modeling was used to develop diagnostic equations to explain DO variability in the Kentucky River Basin. DO concentrations exhibit a normal (Gaussian) frequency distribution (Snedecor and Cochran, 1989) in the Kentucky River Basin. Subsets of DO concentrations, such as data collected in different physiographic regions or in different seasons, exhibit near-normal distributions. When data are distributed in this manner, it is useful to discuss variability in terms of the variance of the frequency distribution.

Models were based principally on the strong relation between temperature and DO concentration. Extra explanatory (independent) variables were found to enhance the model fit and explain extra dimensionality. Explanatory variables used in the models included time of day, instantaneous discharge, total organic carbon concentration, and $\mathrm{pH}$. Biochemical oxygen demand and chlorophyll $a$ data were not collected with sufficient frequency to be important explanatory variables in the models. Time of day and $\mathrm{pH}$ appeared to function as surrogates for photosynthesis, given the observed pattern of covariance between time of day, $\mathrm{pH}$, and DO. Time of day and $\mathrm{pH}$ were positively correlated with $\mathrm{DO}$ concentration.

Stepwise regression, consisting of forward and backward estimation, was used to identify the most appropriate regression models. Four criteria were used to determine which independent variables would be included in the final model: the number of data points involved in the fit, a significant partial $F$-test $(\mathrm{p}<0.05)$, a tolerance value greater than 0.35 , and a Student's $t$-value for the partial regression of 3.0 or greater (Kleinbaum and others, 1988). The DO data set was missing a large number of data points (cases that data points for one or more explanatory variables were not available), and in some circumstances introduction of new explanatory variables to the model significantly reduced the number of paired values used to fit the model. For example, a model fitted to data in the forest cluster had an adjusted multiple $r^{2}$ of 0.836. All criteria were met for each of the explanatory variables; however, this model included only 175 paired data points out of the 384 DO-concentration data points in the forest cluster. Because less than half of the DO-concentration data were included in this model, a different model using fewer explanatory variables but more data points $(n=321)$ ultimately was chosen. The $r^{2}$ value of this latter model was lower than that of the former model, but systematic analysis of the partial sums of squared errors indicated that the latter model explained substantially more variance in the total data than did the former model with the higher $r^{2}$ value (Jaccard and others, 1990).

Tolerance values (Berry, 1993; Fox, 1991; Wilkinson, 1990) were calculated for each independent variable to avoid excessive correlation and, hence, multicollinearity among the independent variables in the model. Tolerance values are calculated as 1 minus the multiple $r^{2}$ between an independent variable and the other independent variables in the model. Consequently, a low tolerance value indicates a high degree of correlation between that variable and the other independent variables as a set. A selection criterion of 0.35 was used. Student's $t$-values of 3.0 or greater were also required for inclusion in the model to ensure that the coefficient of variation of the estimate of the slope coefficient for each variable did not exceed 0.33 .

$P$-order partial regression analysis (where $P=$ the number of standardized independent variables in the model) was used to determine the amount of DO variability (marginal sum of squares) that each independent variable explained, controlling for the effects of the other independent variables (Kleinbaum 
and others, 1988). This approach is necessary if the independent variables are intercorrelated. Under these circumstances, the contribution of any one of the independent variables to the explanation of the variance in the dependent variable may be, at least in part, a function of its correlation with other independent variables in the model (Neter and Waserman, 1974). Systematic analysis of the partial residuals was used to partition the sum of squared errors so that the relative contributions of different sampling sites and sampling schemes could be evaluated.

Initially, models were constructed for six subsets of the data. The subsets were based on the four physiographic regions and the two land-use clusters. Four of these models explained a significant amount of variability ( $>55$ percent) in the DO data. The subsets were the forest and agriculture land-use clusters and the Eastern Coal Field and Inner Bluegrass Regions. The data subsets for the Eastern Coal Field and Inner Bluegrass Regions had greater than 92 percent overlap with the forest cluster and the agriculture cluster, respectively. A comparison of the models between the similar physiographic regions and land-use clusters indicated that the land-use cluster models fit the data better than do the physiographic-region models; therefore, only the models for the two land-use clusters will be discussed. Fortunately, these two subsets included almost 96 percent of the DO data collected, and 95 percent of the data $(n=456)$ were used to construct the models.

\section{Summany of Regression-Model Results}

Two multiple-regression models were fitted to the Kentucky River Basin DO data. The forest model was developed to investigate the factors that affect observed DO concentrations and predict the daytime mean DO concentration in drainage basins with a minimum of 52 percent forested land and a maximum of 43 percent agricultural land. These criteria are developed by choosing a value two standard deviations below the mean of the dominant land use in the cluster. A value two standard deviations above the mean of the second most important land use was selected to ensure that the model was applied to a drainage basin likely to be included in the cluster from which the model was developed (table 16).

The forest model (eq. 2) indicates that variability in DO concentrations associated with this land use can be adequately modeled (predicted) using three independent variables: temperature (TEMP), $\mathrm{pH}$, and the natural logarithm of instantaneous streamflow (LQIN). These three factors explain 73 percent of the variation in DO concentrations in drainage basins fitting the land-use description above. Most of the variability in the model was explained by temperature ( 72 percent), followed by streamflow (19 percent) and $\mathrm{pH}(9$ percent). The model is

$$
\mathrm{DO}_{\text {conc }}=4.057-0.218 * \mathrm{TEMP}+0.907 * \mathrm{pH}+0.541 * \mathrm{LQIN} .
$$

Table 18 lists basic statistics for the forest multiple-regression model. The adjusted multiple $r^{2}=0.728$, and the standard error of the estimate $=1.3 \mathrm{mg} / \mathrm{L} \mathrm{DO}$.

The agricultural model (eq. 3 ) is generally applicable to drainage basins with a minimum of 66 percent agricultural land and a maximum of 24 percent forested land. The amount of urban land is also important for this model and should range from 8 to 18 percent. The model is

$$
\mathrm{DO}_{\text {conc }}=-1.924-0.147 * \text { TEMP }+1.183 * \mathrm{pH}+0.003 * \text { TIME }-0.125 * \mathrm{TOC}+0.516 * \mathrm{LQIN} \text {. }
$$

Table 19 lists statistics for the agriculture multiple-regression model. The adjusted multiple $r^{2}=0.775$, and the standard error of the estimate $=1.4 \mathrm{mg} / \mathrm{L} \mathrm{DO}$. 
Table 18. Statistics for the multiple-regression dissolved-oxygen model for the forested land-use cluster in the Kentucky River Basin

[In, natural logarithm; NA, not applicable. The adjusted multiple $r 2=0.728$, and the standard error of the estimate $=1.301$ milligrams per liter dissolved oxygen]

\begin{tabular}{lccccc}
\hline \multicolumn{1}{c}{ Varlable } & Coefficlent & $\begin{array}{c}\text { Standard } \\
\text { orror }\end{array}$ & Tolerance & Student's $t$ & $\begin{array}{c}\text { Probablilty } \\
\text { (2-tall) }\end{array}$ \\
\hline Temperature & -0.218 & 0.010 & 0.761 & -21.087 & 0 \\
$\mathrm{pH}$ & .907 & .151 & .976 & 6.009 & 0 \\
Instantaneous discharge (In) & .541 & .069 & .776 & 7.790 & 0 \\
Y-intercept & 4.057 & 1.143 & $\mathrm{NA}$ & 3.550 & 0 \\
\hline
\end{tabular}

Table 19. Statistics for the multiple-regression dissolved-oxygen model for the agricultural land-use cluster in the Kentucky River Basin

[In, natural logarithm; NA, not aplicable. The adjusted multiple $\mathrm{r} 2=0.775$, and the standard error of the estimate $=1.423$ milligrams per liter dissolved oxygen]

\begin{tabular}{lccccc}
\hline \multicolumn{1}{c}{ Variable } & Coefficlent & $\begin{array}{c}\text { Standard } \\
\text { error }\end{array}$ & Tolerance & Student's $t$ & $\begin{array}{c}\text { Probability } \\
\text { (2-tall) }\end{array}$ \\
\hline Temperature & -0.147 & 0.020 & 0.617 & -7.369 & 0 \\
$\mathrm{pH}$ & 1.183 & .319 & .853 & 3.705 & 0 \\
Instantaneous discharge (ln) & .516 & .142 & .372 & 3.625 & 0 \\
Total organic carbon & -.125 & .041 & .839 & -3.026 & 0.003 \\
Time & .003 & .001 & .509 & 5.590 & 0 \\
Y-intercept & -1.924 & 2.709 & NA & -.710 & .479 \\
\hline
\end{tabular}

Factors affecting variability in DO concentrations in subbasins with primarily agricultural land differed from subbasins with predominantly forested land. Temperature played a comparatively smaller role in the DO model for the agricultural watersheds, accounting for only about 40 percent of the variability. Time of day, $\mathrm{pH}$, total organic carbon concentration (TOC), and instantaneous streamflow (LQIN) accounted for almost 35 percent of the variability in the model. The model-adjusted multiple $r^{2}=0.775$ indicates that the model explains about 78 percent of the variability in the DO data. This indicates that biochemical factors may have a larger effect on the variability of DO concentrations in the agricultural subbasins than in the forested subbasins.

Time of day and $\mathrm{pH}$ are effective surrogates for photosynthetic activity in the absence of primaryproduction data. The positive relation between time of day and DO concentration is related to the diel fluctuations of photosynthetic activity. DO concentration tends to increase from early morning lows to midafternoon to late-afternoon maxima then decrease through the evening hours, producing a sinusoidal variation over a 24 -hour period. However, sampling in this study generally occurred between midmorning and late aftemoon, thus biasing the TIME variable and explaining the monotonically increasing correlation of time with $\mathrm{DO}$ concentration. $\mathrm{pH}$ values covary with $\mathrm{DO}$, as photosynthetic organisms remove carbon dioxide (carbonic acid) from the water and thus raise the $\mathrm{pH}$ (to maxima bounded by the buffering capacity 
of the water) for the duration of the photosynthetic activity. Once evening falls and the light-dependent (oxygen-producing) phase of photosynthesis ceases, DO concentrations would be expected to decline as respiratory processes predominated.

TOC concentrations had a significant negative relation with DO concentrations in the agriculture cluster only, an indication that DO concentrations decrease as TOC concentrations increase. This relation could result from an increase in BOD caused by increased organic carbon concentrations.

Model estimates were evaluated by comparison with a LQcally WEighted Şcatterplot Smoothing (LOWESS) (Cleveland, 1981; Wilkinson, 1990) fit to the raw data. The LOWESS technique fits a continuous model to the $y$-values of a scatterplot based on every possible $x$-value within the domain specified on the $x$-axis. This is accomplished by iteratively solving a series of local polynomial regressions with robustness weights calculated from the estimated residuals. The end result is a continuous smooth fit through the data that reflects the local nuances of the data and is resistant to the influence of outliers. This approach can fit a locally accurate model to even the most nonlinear data (Hardle, 1990). However, the fitted model is a function of the variables on the $x$-and $y$-axes exclusively. Moreover, this approach provides a visual indication of the functional relation of the dependent variable to the independent variable but does not provide a solution to the mathematical relation.

The first step of model evaluation was plotting the original DO concentration data for each of the forest and agriculture clusters against the days of the water year, October 1 through September 30. A LOWESS smooth was then fit to that data set with an $F$-value $=0.30$. (This means 30 percent of the DO concentration data is used in each estimation of DO concentration at a specified time in the water year). Next, the DO concentrations predicted by the multiple-regression model (MRM) were plotted against water year on the same scale as that used for the original data set. A LOWESS model was then fit to that data. In order to reduce the complexity of the plot and enhance interpretability, the model data were removed and the LOWESS smooth, fit to the model estimate, was left superimposed on the raw-data set and its LOWESS model.

If it can be assumed that the LOWESS model is a best functional fit to the raw data, then deviations of the MRM LOWESS from the raw-data LOWESS indicate when the model is least accurate and perhaps how great the inaccuracy is. Figures 13 and 14 illustrate this approach for the forest and agriculture regression models. Also included with these plots is a plot of the studentized residuals against water year, with a LOWESS model $(F=0.30)$ fit to the data. For ease of interpretation, only the LOWESS smooth is presented (bounded by one standard deviation above and below zero). This plot allows one to determine whether the model is overestimating or underestimating DO concentration, and the magnitude of overestimation or underestimation, at a designated time of the year. This usually can be done by means of a comparison with the raw-data LOWESS. However, for the agriculture land-use cluster, the multipleregression model and the LOWESS smooth it produces appear to produce a better fit to the original (raw) data than does the raw-data LOWESS. Further, one can easily see how well the multiple-regression model fits the LOWESS smooth by observing the deviation of its studentized residual smooth from the zero line. A straight-line fit indicates an accurate model.

DO concentrations in the Kentucky River Basin varied annually, seasonally, and daily. Annual variability was not significant in the basin. Daily variability appeared to be primarily a function of biological activity. DO concentrations measured in samples collected in the winter were about $3.0 \mathrm{mg} / \mathrm{L}$ higher than DO concentrations measured in samples collected in the summer (data not shown), an indication that seasonal variability was principally affected by changes in temperature or DO solubility (figs. 13 and 14). 


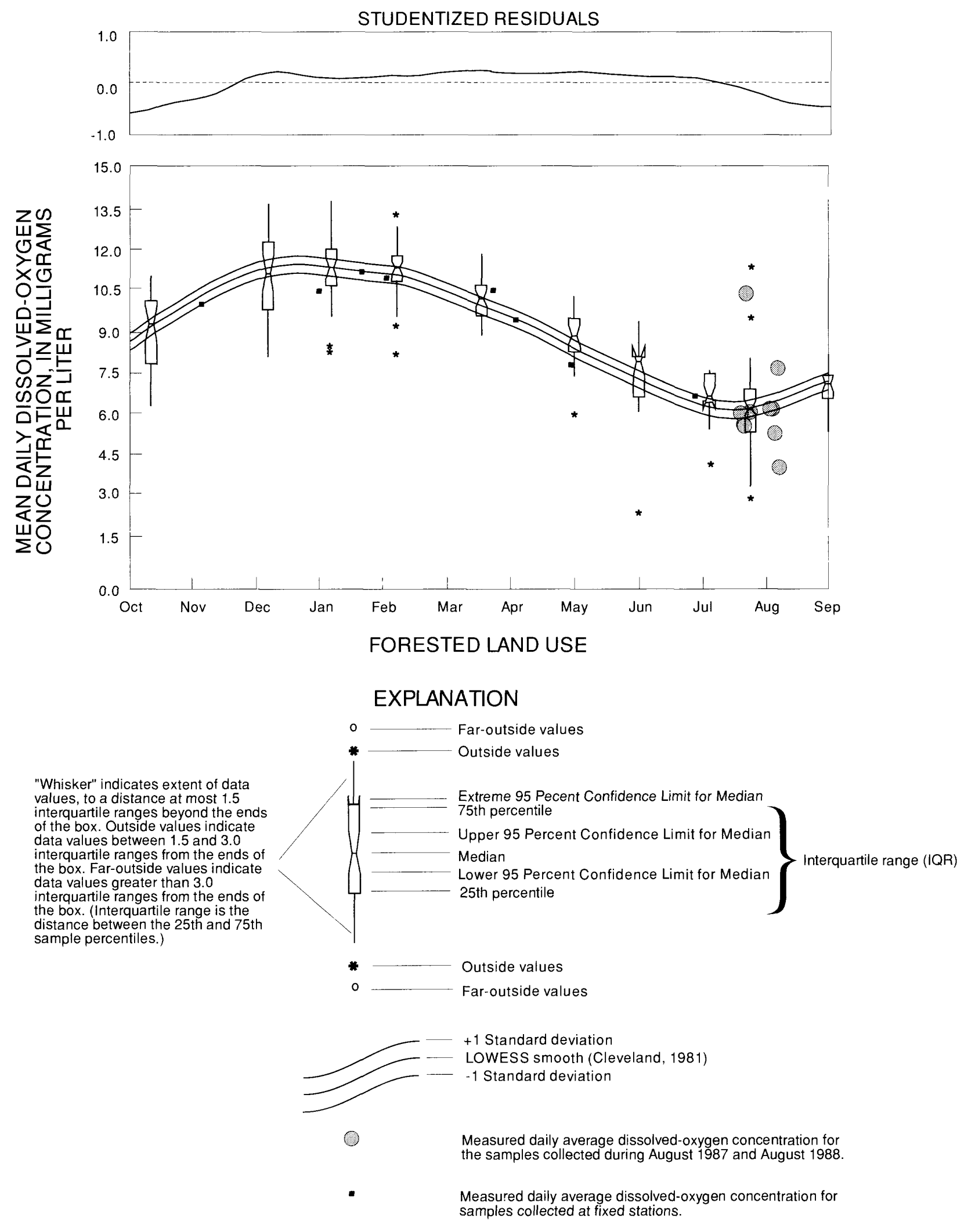

Figure 13. Dissolved-oxygen concentrations in streams in the forested land-use cluster in the Kentucky River Basin during April 1987 - March 1990. 


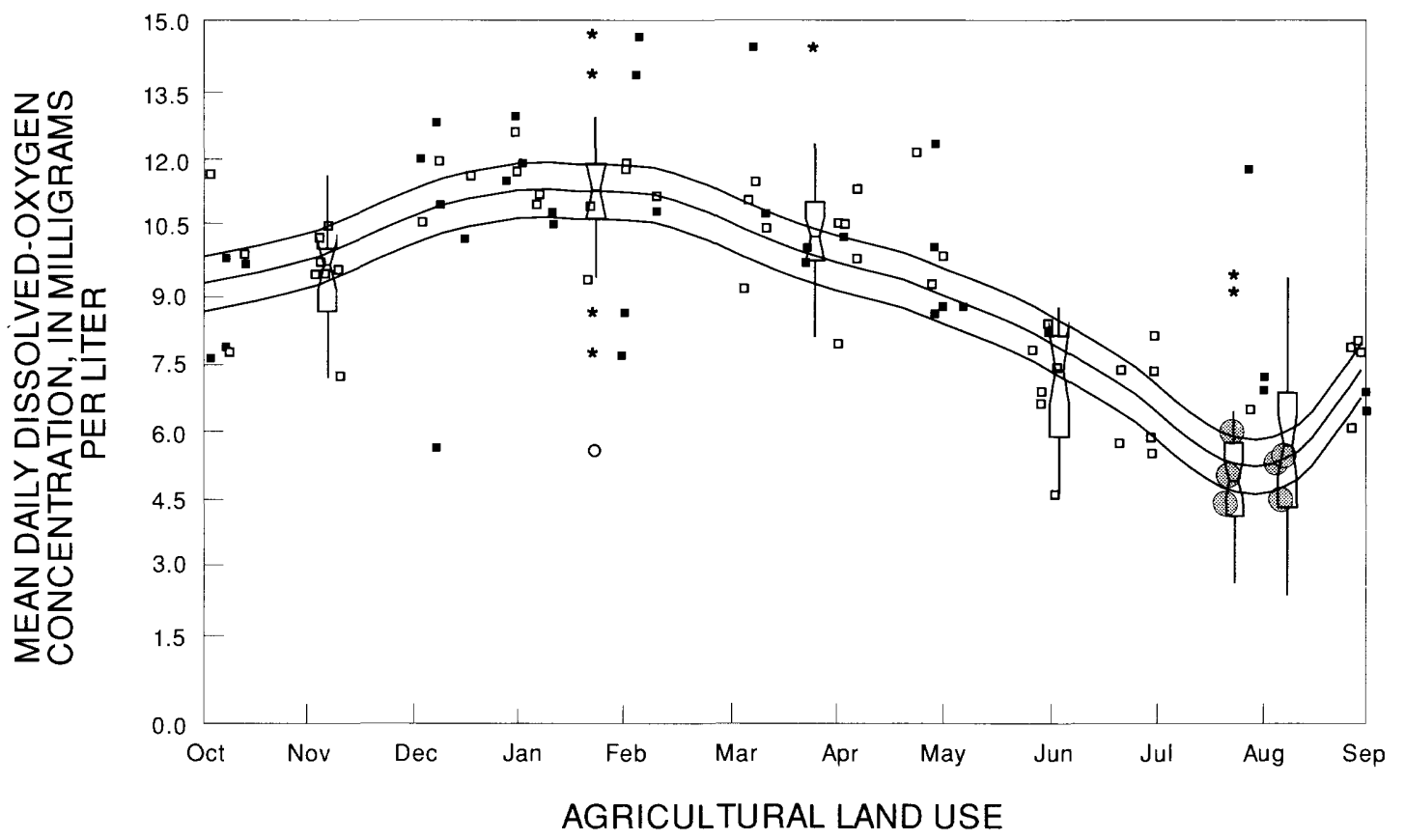

\section{EXPLANATION}

"Whisker" indicates extent of data values, to a distance at most 1.5 interquartile ranges beyond the ends of the box. Outside values indicate data values between 1.5 and 3.0 interquartile ranges from the ends of the box. Far-outside values indicate data values greater than 3.0

interquartile ranges from the ends of the box. (Interquartile range is the distance between the 25th and 75th sample percentiles.)

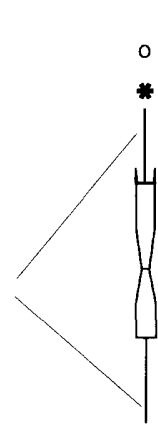

Far-outside values

* - Outside values

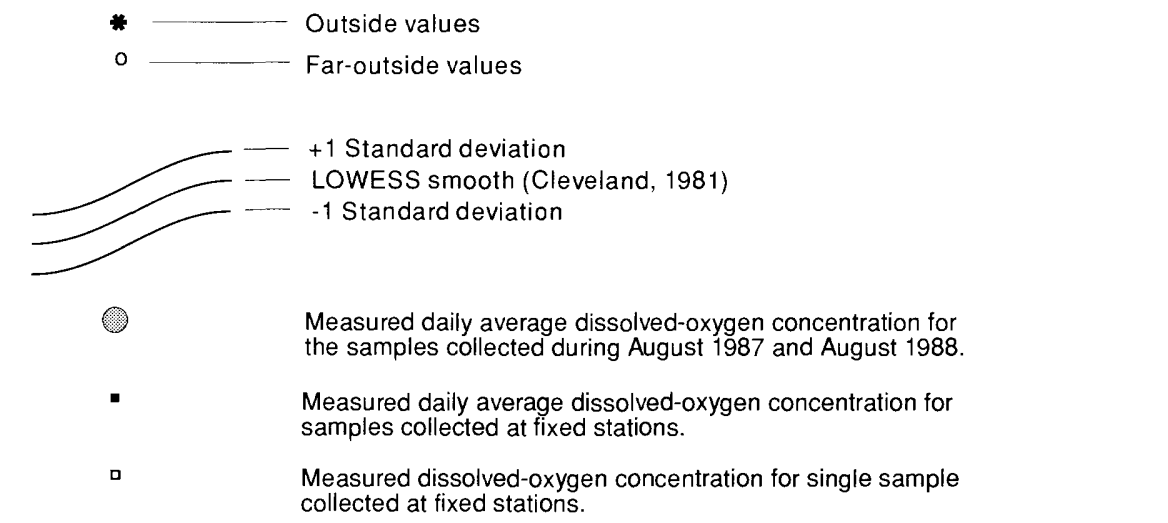

Figure 14. Dissolved-oxygen concentrations in streams in the agricultural land-use cluster in the Kentucky River Basin during April 1987 - March 1990. 
To summarize, three processes controlled DO concentrations in the Kentucky River Basin: solubility processes; oxygen-demanding processes; and oxygen producing processes. Oxygen producing and demanding processes were most important in the agricultural land-use cluster. In the agricultural land-use cluster, higher nutrient concentrations and greater light availability may have enhanced primary productivity, compared to the forested land-use cluster. Alternatively, higher nutrient concentrations and the associated higher organic-carbon content may have contributed to greater oxygen demand. Temperature-related solubility processes were more important in the forested land-use cluster. Oxygendemanding processes were relatively less important in the forested land-use cluster because of greater stream velocity and hydromechanical reaeration and cooler water temperatures, compared to conditions in the agricultural land-use cluster.

There was an observable difference in dissolved-oxygen concentrations in subbasins in the forested land-use cluster and the agricultural land-use cluster. Mean dissolved-oxygen concentrations were significantly higher in the forested cluster $(8.3 \mathrm{mg} / \mathrm{L})$ compared to the agricultural cluster $(7.5 \mathrm{mg} / \mathrm{L})$, based on a paired-means test. Dissolved-oxygen concentrations were also less variable in the forested land-use cluster $($ C.V. $=0.291)$ compared to the agricultural land-use cluster $(C . V .=0.383)$. Daily mean dissolved-oxygen concentrations varied seasonally in the Kentucky River Basin. Minimum concentrations occurred in summer, and maximum concentrations occurred in winter in both land-use clusters. During 1987-90, dissolved-oxygen concentrations were lowest in tributary streams; DO concentrations measured in the Kentucky River main stem were generally above $5 \mathrm{mg} / \mathrm{L}$. Less dilution of oxygen-demanding wastes and higher maximum temperatures in the tributaries likely contributed to this observed difference.

\section{SUMMARY AND CONCLUSIONS}

Water quality in the Kentucky River Basin is affected by many factors. Natural factors of importance include geology, soil type, topography, and precipitation patterns. Human factors include population distribution, water use, land use, and wastewater-treatment practices. These factors interact in various ways and vary in importance throughout the basin.

Oil-production activities were the source of barium, boron, bromide, chloride, magnesium, sodium, and strontium in several subbasins. Overall, oil-producing subbasins in the Kentucky River Basin contribute a large percentage of the dissolved-constituent loads of the Kentucky River.

The spatial distribution of metals and other trace elements in streambed sediments from the Kentucky River Basin is the result of regional differences in geology, land use and land cover, and human activities. Soils and streambed sediments derived from geologic materials in the Eastem Coal Field Region contain high concentrations of aluminum, iron, and titanium, whereas soils and streambed sediments in the Knobs Region contain high concentrations of chromium, copper, lead, nickel, and vanadium. In the Bluegrass Region, soils and streambed sediments contain high concentrations of calcium, phosphorus, strontium, and yttrium. Land disturbance, especially coal-mining and agricultural activities, exposes geologic material to weathering and consequently increases transport of sediment and trace elements to streams. In urban and industrial areas, high concentrations of arsenic, barium, chromium, iron, lead, manganese, nickel, and zinc found in streambed sediments probably result from urban stormwater runoff, point-source discharges, and waste-management practices. Significant upward trends in concentrations of aluminum, iron, magnesium, manganese, and zinc were indicated at one or more fixed stations in the Kentucky River Basin since the mid-1970's or early 1980's.

The temporal and spatial variability of nutrients, suspended sediments, and pesticides in the Kentucky River Basin were affected by numerous factors including land-use type, agricultural and urban runoff, WWTP effluent, and the distribution of algal populations. Nutrients from WWTP effluent substantially 
affected water quality during low-flow conditions in many tributary streams. The temporal variability of nutrients and dissolved oxygen was strongly influenced by the presence of algal populations, particularly in the Kentucky River main stem. A large amount of suspended sediment originates in the Eastern Coal Field Region, but contributions of suspended sediment from the Red River and other tributary streams of the Knobs Region also are important. Water and streambed-sediment samples collected at sites throughout the basin contained numerous herbicides and insecticides, reflecting agricultural as well as residential pesticide-use patterns.

Fecal-indicator bacteria were a water-quality issue of concern in the Kentucky River Basin during 1987-90. About 375 to 575 river miles in the Kentucky River Basin were contaminated by fecal-coliform bacteria, as indicated by the 1988 synoptic survey. In the downstream part of the basin, there were no significant changes in fecal-indicator bacteria counts during 1987-90. In the upper part of the basin during 1980-90, median counts of fecal-coliform bacteria decreased, largely in response to regulatory actions that included swimming advisories. Even though water samples collected at stations in the upper part of the basin indicate a decrease in the median counts of fecal-indicator bacteria, almost one-third of the 29 stations in the basin where $E$. coli counts did not meet full-body-contact criteria were in the North Fork of the Kentucky River. Efforts to improve the sanitary quality of water in the North Fork of the Kentucky River continue.

Dissolved-oxygen (DO) concentrations in the basin generally exceeded the minimum level needed for the support of aquatic life. Three processes controlled DO concentrations in the Kentucky River Basin: solubility processes; oxygen-demanding processes; and oxygen-producing processes. These processes varied spatially and temporally in rate and importance in the Kentucky River Basin. DO concentrations in subbasins appeared to be related to land use. Median DO concentrations were higher $(8.3 \mathrm{mg} / \mathrm{L})$ and less variable in subbasins where forest was the dominant land use. High nutrient concentrations and associated high organic-carbon concentrations may have contributed to lower median DO concentrations $(7.5 \mathrm{mg} / \mathrm{L})$ in subbasins where agricultural land use predominated. DO concentrations were higher in the Kentucky River main stem than in tributary streams; photosynthesis by phytoplankton populations in the main stem of the river likely contributed to this pattern. 


\section{REFERENCES CITED}

American Public Health Association, 1987, Standard methods for the examination of water and wastewater (18th ed.): Washington, D.C., [variously paged].

Berry, W.W., 1993, Understanding regression assumptions: Newbury Park, Calif., Sage Publications, 91 p.

Bevington, P.R., and Robinson, D.K., 1992, Data reduction and error analysis for the physical sciences: New York, McGraw-Hill, 328 p.

Bradfield, A.D., and Porter, S.D., 1990, Summary of biological investigations relating to surface-water quality in the Kentucky River Basin, Kentucky: U.S. Geological Survey Water-Resources Investigations Report 90-4051, 63 p.

Britton, L.J., and Greeson, P.E., eds., 1987, Methods for collection and analysis of aquatic biological and microbiological samples: U.S. Geological Survey Techniques of Water-Resources Investigations, book 5, chap. A4, 363 p.

Chambers, J.M., Cleveland, W.S., Kleiner, Beat, and Tukey, P.A., 1983, Graphical methods for data analysis: Belmont, Calif., Wadsworth International Group, 395 p.

Cleveland, W.S., 1981, LOWESS -A program for smoothing scatterplots by robust locally weighted regression: American Statistician, v. 35, p. 54-61.

Craun, G.F., 1991, Causes of waterborne outbreaks in the United States: Water Science and Technology, v. 4, no. 2, p. 17-20.

Decker, Ronnie, ed., 1991, Kentucky economic statistics: Frankfort, Ky., Department of Existing Business and Industry, Division of Research and Planning, $129 \mathrm{p}$.

Dufour, A.P., 1977, Escherichia coli-The fecal coliform, in Haodley, A.W., and Dutka, B.J., eds., Bacterial indicators/health hazards associated with water: Philadelphia, American Society for Testing and Materials, Special Technical Publication 635, p. 48-58.

Dufour, A.P., Stricklane, E.R., and Cabelli, V.J., 1981, Membrane filter method for enumerating Escherichia Coli: Applied and Environmental Microbiology, v. 41, no. 5, p. 1,152-1,158.

Edberg, S.C., 1992, Health effects of microbes isolated from drinking water, in Regulating drinking water quality: Chelsea, Mich., Lewis Publishers, p. 167-174.

Elam, A.B., Jr., Haan, C.T., Barfield, B.J., and Bridges, T.C., 1972, Precipitation probabilities for Kentucky: Lexington, Ky., University of Kentucky, College of Agriculture, Progress Report 202, 55 p.

Evaldi, R.D., and Kipp, J.A., 1991, Effects of oil production on water resources in the Kentucky River Basin, Kentucky: U.S. Geological Survey Water-Resources Investigations Report 90-4191, 58 p.

Fishman, M.J., and Friedman, L.C., eds., 1989, Methods for determination of inorganic substances in water and fluvial sediments: U.S. Geological Survey Techniques of Water-Resources Investigations, book 5, chap. A1, 545 p.

Flint, R.F., 1983, Fluvial sedimentation in Kentucky: U.S. Geological Survey Water-Resources Investigations Report 83-4152, 75 p.

Fox, John, 1991, Regression diagnostics: Newbury Park, Calif., Sage Publications, 92 p.

Friedman, L.C., and Erdmann, D.E., 1983, Quality assurance practices for the chemical and biological analyses of water and fluvial sediments: U.S. Geological Survey Techniques of Water-Resources Investigations, book 5, chap. A6, $181 \mathrm{p}$.

Gianessi, L.P., 1986, Water pollutant discharges and pesticide usage estimates for NAWQA surface-water study regions: Washington, D.C., Resources for the Future, 19 p. 
Griffin, M.S., Martin, G.R., and White, K.D., 1994, Surface-water-quality assessment of the Kentucky River Basin, Kentucky-Fixed-station network and selected water-quality data, April 1987 through August 1991:

U.S. Geological Survey Water-Resources Investigations Report 94-4029, 149 p.

Haag, K.H., and Porter, S.D., 1995, Water-quality assessment of the Kentucky River Basin, Kentucky-Nutrients, sediments, and pesticides in streams, 1987-90: U.S. Geological Survey Water-Resources Investigations Report 94-4227, 135 p.

Hair, J.F., Jr., Anderson, R.E., and Tatham, R.L., 1987, Multivariate data analysis, with readings: New York, Macmillan Publishing Co., 449 p.

Hardle, Wolfgang, 1990, Applied nonparametric regression: New York, Cambridge University Press, 333 p.

Hartigan, J.A., 1975, Clustering algorithms: New York, John Wiley, 351 p.

Hirsch, R.M., Alley, W.M., Wilber, W.G., 1988, Concepts for a national water-quality assessment program:

U.S. Geological Survey Circular 1021, 42 p.

Jaccard, James, Turisi, Robert, and Wan, C.K., 1990, Interaction effects in multiple regression: Newbury Park, Calif., Sage Publications, 95 p.

Jones, B.E., 1987, Quality control manual of the U.S. Geological Survey's National Water-Quality Laboratory: U.S. Geological Survey Open-File Report 87-457, 17 p.

Kaspar, C.W., Burgess, J.L., Knight, I.T., and Colwell, R.R., 1990, Antibiotic resistance indexing of Escherichia coli to identify sources of fecal contamination in water: Canadian Journal of Microbiology, v. 36, no. 12, p. 891-894.

Kentucky Natural Resources and Environmental Protection Cabinet, 1986, Kentucky Report to Congress on water quality, 1986-87: $192 \mathrm{p}$.

1990a, Kentucky Report to Congress on water quality, 1988-89: $189 \mathrm{p}$.

1990b, Surface water standards: 401 KAR 5:031 as amended, 19 p.

1992a, Kentucky Report to Congress on water quality, 1990-91: $191 \mathrm{p}$.

1992b, Kentucky Division of Water administrative regulations, Title 401, chap. 5: [variously paged].

Kleinbaum, D.G., Kupper, L.L., and Muller, K.E., 1988, Applied regression analysis and other multivariable methods: Boston, PWS-KENT Publishing Co., 718 p.

Mattraw, H.C., Jr., Wilber, W.G., and Alley, W.M., 1989, Quality-assurance plan for the pilot National Water-Quality Assessment program: U.S. Geological Survey Open-File Report 88-726, 21 p.

Melcher, N.B., and Ruhl, K.J., 1984, Streamflow and basin characteristics at selected sites in Kentucky:

U.S. Geological Survey Open-File Report 84-704, 80 p.

Neter, John, and Waserman, William, 1974, Applied linear statistical models-Regression, analysis of variance, and experimental design: Georgetown, Ont., Richard D. Irwin, p. 842.

Parmelee, M.A., 1990, Outbreak reveals vulnerability of water operations: American Water Works Association, Mainstream, v. 34, p. $1,9$.

Porter, S.D.,White, K.D., and Clark, J.R., 1995, Water-quality assessment of the Kentucky River Basin, KentuckyDistribution of metals and other trace elements in sediment and water, 1987-90: U.S. Geological Survey Water-Resources Investigations Report 94-4134, 184 p.

Smith, J.A., Witkowski, P.J., and Fusillo, T.V., 1987, Manmade organic compounds in the surface waters of the United States-A review of current understanding: U.S. Geological Survey Open-File Report 87-209, 182 p. 
Smoot, J.L., Liebermann, T.D., Evaldi, R.D., and White, K.D.,1991, Surface water-quality assessment of the Kentucky River Basin, Kentucky -Analysis of available water-quality data through 1986: U.S. Geological Survey Open-File Report 90-360, 209 p.

Snedecor, G.W., and Cochran, W.G., 1989, Statistical methods (8th ed.): Ames, Iowa, Iowa State University Press, $503 \mathrm{p}$.

Thomann, R.V., and Mueller, J.A., 1987, Principles of surface water quality modeling and control: New York, Harper and Row, $644 \mathrm{p}$.

Tukey, J.W., 1977, Exploratory data analysis: Menlo Park, Calif., Addison-Wesley Publishing Co., 688 p.

U.S. Department of Agriculture, 1981, Report for Kentucky River Basin: Lexington, Ky., Economics and Statistics Service, Forest Service, and Soil Conservation Service, in cooperation with Kentucky Soil and Water Conservation Commission and Kentucky Natural Resources and Environmental Protection Cabinet, 119 p.

U.S. Environmental Protection Agency, 1985a, Test method for Escherichia coli and enterococci in water by the membrane filtration procedure: EPA-600/4-85/076, $25 \mathrm{p}$.

1985b, Ambient water quality criterion for dissolved oxygen: Freshwater aquatic life draft submitted for comments in Federal Register 50(76):15,634, April 11, 1985, 34 p.

1986, Ambient water quality criteria for bacteria: EPA-440/5-84-002, $43 \mathrm{p}$.

Ward, J.R., and Harr, C.A., 1990, Methods for collection and processing of surface water and bed-material samples for physical and chemical analysis: U.S. Geological Survey Open-File Report 90-140, 71 p.

White, K.D., Smoot, J.L., Jackson, J.K., and Choquette, A.F., 1987, Surface water-quality assessment of the Kentucky River Basin, Kentucky-Project description: U.S. Geological Survey Open-File Report 87-234, 39 p.

Wilkinson, L., 1990, SYGRAPH—The system for graphics: Evanston, Ill., Systat, 547 p.

Witkowski, P.J., Smith, J.A., Fusillo, T.V., and Chiou, C.T., 1987, A review of surface-water sediment fractions and their interactions with persistent manmade organic compounds: U.S. Geological Survey Circular 993, 39 p. 